\title{
Stealth and Bright Monomolecular Fluorescent Organic Nanoparticles Based on Folded Amphiphilic Polymer
}

\author{
Mayeul Collot, Jérémy Schild, Kyong T. Fam, Redouane Bouchaala, Andrey S. Klymchenko
}

\section{Synthesis of amino BODIPYs}

Amino-BODIPY 1 (BDP1) with different linkers

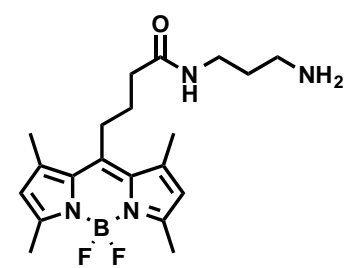

BDP1<smiles>Cc1cc(C)n(P)c1CCCC(=O)O</smiles>

1

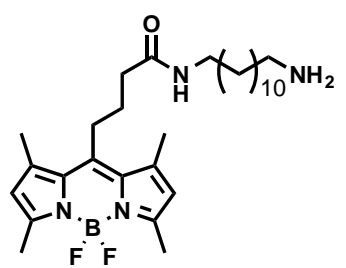

BDP1- $\mathrm{C}_{12}$
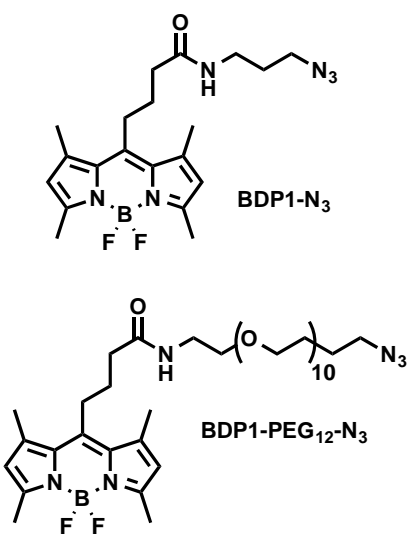

BDP1-C 12<smiles>Cc1cc(C)n(P)c1CCCC(=O)NCCOCC(C)(C)CN</smiles>

BDP1-PEG 12
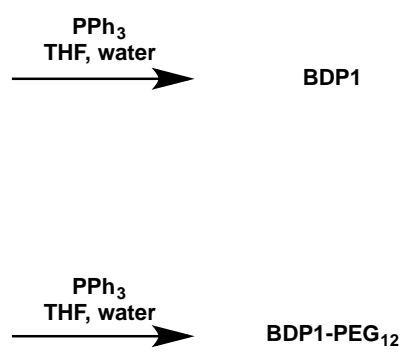

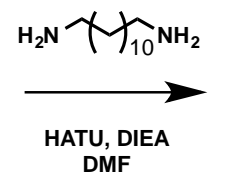

1 was synthesized according to a described procedure. ${ }^{1}$

Azidopropylamine was synthesized according to a described procedure. ${ }^{2}$

$\mathbf{N H}_{2}$-PEG-N 3 was obtained from Iris biotech (Germany).

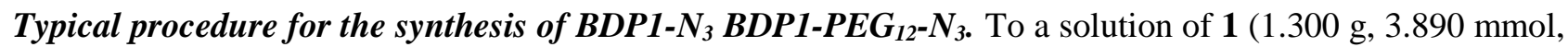
$1 \mathrm{eq})$ in DMF $(35 \mathrm{~mL})$ was added azidopropylamine (700 mg, $7.000 \mathrm{mmol}, 1.8 \mathrm{eq})$, DIEA (1.5g, 11.67 mmol, $3 \mathrm{eq}$ ) and HATU (1.77 g, $4.670 \mathrm{mmol}, 1.2 \mathrm{eq})$. The solution was stirred at room temperature for $1 \mathrm{~h}$. The reaction was monitored by TLC (DCM/Acetone: 99/1) until completion. The solvents were evaporated under reduced pressure. The crude was purified by column chromatography on silica gel (DCM/Acetone: 99/1) to obtain an orange solid (95\%).

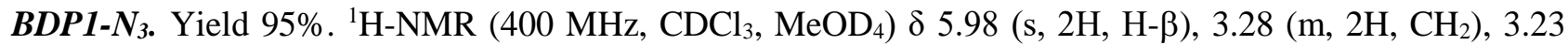
(m, 2H, CH $\mathrm{CH}_{2}, 2.92\left(\mathrm{~m}, 2 \mathrm{H}, \mathrm{CH}_{2}\right), 2.43\left(\mathrm{~s}, 6 \mathrm{H}, 2 \mathrm{CH}_{3}\right), 2.33\left(\mathrm{~s}, 6 \mathrm{H}, 2 \mathrm{CH}_{3}\right), 1.87\left(\mathrm{~m}, 2 \mathrm{H}, \mathrm{CH}_{2}\right), 1.70(\mathrm{~m}, 2 \mathrm{H}$, $\left.\mathrm{CH}_{2}\right) .{ }^{13} \mathrm{C}-\mathrm{NMR}\left(101 \mathrm{MHz}, \mathrm{CDCl}_{3}, \mathrm{MeOD}_{4}\right) \delta 168.2(\mathrm{CO}), 150.1(\mathrm{C} \mathrm{Ar}), 141.4(\mathrm{C} \mathrm{Ar}), 136.6$ (C Ar), 127.5 
(C Ar), 117.8 (C Ar), $43.3\left(\mathrm{CH}_{2}\right), 33.2\left(\mathrm{CH}_{2}\right), 33.1\left(\mathrm{CH}_{2}\right), 32.0\left(\mathrm{CH}_{2}\right), 24.7\left(\mathrm{CH}_{2}\right), 23.4\left(\mathrm{CH}_{2}\right), 12.3\left(\mathrm{CH}_{3}\right)$, $10.4\left(\mathrm{CH}_{3}\right)$. HRMS $\left(\mathrm{ESI}^{+}\right)$, calcd for $\mathrm{C}_{20} \mathrm{H}_{27} \mathrm{BFN}_{6} \mathrm{O}[\mathrm{M}-\mathrm{F}]^{+}$397.2323, found 397.2313.

BDP1-PEG $\boldsymbol{I}_{12}-\mathrm{N}_{3}$. Yield $77 \%{ }^{1} \mathrm{H}-\mathrm{NMR}\left(400 \mathrm{MHz}, \mathrm{CDCl}_{3}\right) \delta 6.04(\mathrm{~s}, 2 \mathrm{H}, \mathrm{H}-\beta), 3.62(\mathrm{~m}, 42 \mathrm{H}, 40 \mathrm{H}$ for PEG and $\left.1 \mathrm{CH}_{2}\right), 3.55(\mathrm{~m}, 2 \mathrm{H}, \mathrm{CH} 2), 3.44(\mathrm{~m}, 2 \mathrm{H}, \mathrm{CH} 2), 3.37(\mathrm{~m}, 2 \mathrm{H}, \mathrm{CH} 2), 3.01(\mathrm{~m}, 2 \mathrm{H}, \mathrm{CH} 2), 2.50(\mathrm{~s}, 3 \mathrm{H}$, $\left.\mathrm{CH}_{3}\right), 2.43\left(\mathrm{~s}, 3 \mathrm{H}, \mathrm{CH}_{3}\right), 2.35(\mathrm{~m}, 2 \mathrm{H}, \mathrm{CH} 2), 1.96(\mathrm{~m}, 2 \mathrm{H}, \mathrm{CH} 2) .{ }^{13} \mathrm{C}-\mathrm{NMR}\left(101 \mathrm{MHz}, \mathrm{CDCl}_{3}\right) \delta 171.1(\mathrm{CO})$, 152.9 (C Ar), 144.7 (C Ar), 139.7 (C Ar), 130.5 (C Ar), 120.7 (C Ar), $70.7\left(\mathrm{CH}_{2} \mathrm{PEG}\right), 70.6\left(\mathrm{CH}_{2} \mathrm{PEG}\right)$, 70.6 ( $\mathrm{CH}_{2}$ PEG), 70.5 ( $\left.\mathrm{CH}_{2} \mathrm{PEG}\right), 70.5$ ( $\left.\mathrm{CH}_{2} \mathrm{PEG}\right), 70.4\left(\mathrm{CH}_{2} \mathrm{PEG}\right), 70.4\left(\mathrm{CH}_{2} \mathrm{PEG}\right), 70.2\left(\mathrm{CH}_{2} \mathrm{PEG}\right)$, $70.0\left(\mathrm{CH}_{2} \mathrm{PEG}\right), 69.8\left(\mathrm{CH}_{2} \mathrm{PEG}\right), 50.7\left(\mathrm{CH}_{2}\right), 39.3\left(\mathrm{CH}_{2}\right), 36.2\left(\mathrm{CH}_{2}\right), 27.6\left(\mathrm{CH}_{2}\right), 27.5\left(\mathrm{CH}_{2}\right), 16.4\left(\mathrm{CH}_{3}\right)$, 14.4 $\left(\mathrm{CH}_{3}\right)$. HRMS $\left(\mathrm{ESI}^{+}\right)$, calcd for $\mathrm{C}_{41} \mathrm{H}_{69} \mathrm{BF}_{2} \mathrm{~N}_{6} \mathrm{O}_{12} \mathrm{Na}[\mathrm{M}+\mathrm{Na}]^{+} 909.5034$, found 909.4923 .

Synthesis of BDP1-C $\boldsymbol{C}_{12}$. To a solution of $1(300 \mathrm{mg}, 0.898 \mathrm{mmol}, 1 \mathrm{eq})$ in DMF (40 mL) was added 1,12dodecyldiamine (539 mg, $2.695 \mathrm{mmol}, 3 \mathrm{eq}$ ), DIEA (348mg, $2.695 \mathrm{mmol}, 3 \mathrm{eq}$ ) and HATU (409m g, 1.078 mmol, 1.2eq). The solution was stirred at room temperature for 1 hour. The reaction was monitored by TLC (DCM/MeOH/NEt ${ }_{3}:$ 90/9/1) until completion. The DMF was removed under reduced pressure. The crude was purified by column chromatography on silica gel (DCM/MeOH/NEt 3 : 90/9/1) to obtain an orange solid with metallic reflect $\left(\mathbf{B D P 1}_{\mathbf{1 2}}, 21.9 \mathrm{mg}, 5 \%\right) .{ }^{1} \mathrm{H}-\mathrm{NMR}\left(400 \mathrm{MHz}, \mathrm{CDCl}_{3}\right) \delta 6.04(\mathrm{~s}, 2 \mathrm{H}, \mathrm{H}-\beta), 3.23(\mathrm{~m}$, $\left.2 \mathrm{H}, \mathrm{CH}_{2}\right), 3.43\left(\mathrm{~m}, 2 \mathrm{H}, \mathrm{CH}_{2}\right), 3.00\left(\mathrm{~m}, 2 \mathrm{H}, \mathrm{CH}_{2}\right), 2.67\left(\mathrm{~m}, 2 \mathrm{H}, \mathrm{CH}_{2}\right), 2.50\left(\mathrm{~s}, 3 \mathrm{H}, \mathrm{CH}_{3}\right), 2.41\left(\mathrm{~s}, 3 \mathrm{H}, \mathrm{CH}_{3}\right)$, $2.30\left(\mathrm{~m}, 2 \mathrm{H}, \mathrm{CH}_{2}\right), 1.95\left(\mathrm{~m}, 2 \mathrm{H}, \mathrm{CH}_{2}\right), 1.48\left(\mathrm{~m}, 4 \mathrm{H}, 2 \mathrm{CH}_{2}\right), 1.25\left(\mathrm{~m}, 16 \mathrm{H}, 8 \mathrm{CH}_{2}\right) .{ }^{13} \mathrm{C}-\mathrm{NMR}(101 \mathrm{MHz}$, $\left.\mathrm{CDCl}_{3}\right) \delta 171.4(\mathrm{CO}), 154.0(\mathrm{C} \mathrm{Ar}), 145.4(\mathrm{C} \mathrm{Ar}), 140.5(\mathrm{C} \mathrm{Ar}), 131.5(\mathrm{C} \mathrm{Ar}), 121.7(\mathrm{C} \mathrm{Ar}), 42.3\left(\mathrm{CH}_{2}\right)$, $39.7\left(\mathrm{CH}_{2}\right), 36.3\left(\mathrm{CH}_{2}\right), 33.8\left(\mathrm{CH}_{2}\right), 30.9\left(\mathrm{CH}_{2}\right), 29.6\left(\mathrm{CH}_{2}\right), 29.5\left(\mathrm{CH}_{2}\right), 29.5\left(\mathrm{CH}_{2}\right), 29.4\left(\mathrm{CH}_{2}\right), 29.4\left(\mathrm{CH}_{2}\right)$, $27.5\left(\mathrm{CH}_{2}\right), 27.4\left(\mathrm{CH}_{2}\right), 26.9\left(\mathrm{CH}_{2}\right), 26.8\left(\mathrm{CH}_{2}\right), 16.4\left(\mathrm{CH}_{3}\right), 14.4\left(\mathrm{CH}_{3}\right)$. HRMS $\left(\mathrm{ESI}^{+}\right)$, calcd for $\mathrm{C}_{29} \mathrm{H}_{48} \mathrm{BF}_{2} \mathrm{NO}[\mathrm{M}+\mathrm{H}]^{+}$516.3811, found 517.3897.

Typical procedure for Staudinger azide reduction. To a solution of BDP1-N $\mathbf{N}_{\mathbf{3}}$ (619 mg, $1.488 \mathrm{mmol}, 1 \mathrm{eq}$ ), in THF $(16 \mathrm{~mL})$ with water $(0.8 \mathrm{~mL})$ was added $\mathrm{PPh}_{3}(585 \mathrm{mg}, 2.232 \mathrm{mmol}, 1.5 \mathrm{eq})$. The solution was stirred overnight at $40^{\circ} \mathrm{C}$. The reaction was monitored by TLC (DCM/MeOH/NEt 3 : 90/9/1) until completion. The solvents were evaporated under reduced pressure and the product was purified by Flash chromatography on silica gel with solid deposit using Celite ${ }^{\circledR}\left(\mathrm{DCM} / \mathrm{MeOH} / \mathrm{NEt}_{3}\right.$ : 90/9/1) to obtain an orange solid with metallic reflect (BDP1, $404 \mathrm{mg}, 70 \%$ ).

BDP1. Yield 70\%, ${ }^{1} \mathrm{H}-\mathrm{NMR}\left(400 \mathrm{MHz}, \mathrm{CDCl}_{3}\right.$ and Methanol-D4) $\delta 6.00(\mathrm{~s}, 2 \mathrm{H}, \mathrm{H}-\beta), \delta 3.15\left(\mathrm{~m}, 2 \mathrm{H}, \mathrm{CH}_{2}\right.$ ), $2.91\left(\mathrm{~m}, 2 \mathrm{H}, \mathrm{CH}_{2}\right), 2.61\left(\mathrm{~m}, 2 \mathrm{H}, \mathrm{CH}_{2}\right), 2.38\left(\mathrm{~s}, 6 \mathrm{H}, 2 \mathrm{CH}_{3}\right), 2.34\left(\mathrm{~s}, 6 \mathrm{H}, 2 \mathrm{CH}_{3}\right), 2.28\left(\mathrm{~m}, 2 \mathrm{H}, \mathrm{CH}_{2}\right), 1.84(\mathrm{~m}$, $\left.2 \mathrm{H}, \mathrm{CH}_{2}\right), 1.58\left(\mathrm{~m}, 2 \mathrm{H}, \mathrm{CH}_{2}\right) .{ }^{13} \mathrm{C}-\mathrm{NMR}\left(101 \mathrm{MHz}, \mathrm{CDCl}_{3}, \mathrm{MeOD}_{4}\right) \delta 173.5(\mathrm{CO}), 158.5(\mathrm{C} \mathrm{Ar}), 145.6(\mathrm{C}$ $\mathrm{Ar}), 140.9(\mathrm{C} \mathrm{Ar}), 131.3(\mathrm{C} \mathrm{Ar}), 121.5(\mathrm{C} \mathrm{Ar}), 38.2\left(\mathrm{CH}_{2}\right), 36.8\left(\mathrm{CH}_{2}\right), 35.8\left(\mathrm{CH}_{2}\right), 31.3\left(\mathrm{CH}_{2}\right), 27.7\left(\mathrm{CH}_{2}\right)$, $27.4\left(\mathrm{CH}_{2}\right), 15.6\left(\mathrm{CH}_{3}\right), 13.6\left(\mathrm{CH}_{3}\right)$. HRMS $\left(\mathrm{ESI}^{+}\right)$, calcd for $\mathrm{C}_{20} \mathrm{H}_{29} \mathrm{BF}_{2} \mathrm{~N}_{4} \mathrm{O}[\mathrm{M}-\mathrm{F}]^{+} 390.2402$, found 390.2476.

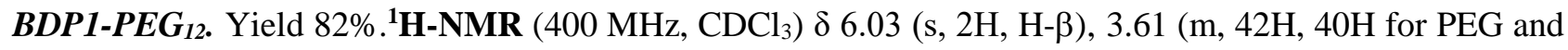
$\left.1 \mathrm{CH}_{2}\right), 3.50\left(\mathrm{~m}, 2 \mathrm{H}, \mathrm{CH}_{2}\right), 3.43\left(\mathrm{~m}, 2 \mathrm{H}, \mathrm{CH}_{2}\right), 2.99\left(\mathrm{~m}, 2 \mathrm{H}, \mathrm{CH}_{2}\right), 2.86\left(\mathrm{~m}, 2 \mathrm{H}, \mathrm{CH}_{2}\right), 2.49\left(\mathrm{~s}, 3 \mathrm{H}, \mathrm{CH}_{3}\right)$, $2.41\left(\mathrm{~s}, 3 \mathrm{H}, \mathrm{CH}_{3}\right), 2.34\left(\mathrm{~m}, 2 \mathrm{H}, \mathrm{CH}_{2}\right), 1.96\left(\mathrm{~m}, 2 \mathrm{H}, \mathrm{CH}_{2}\right) .{ }^{13} \mathbf{C}-\mathbf{N M R}\left(101 \mathrm{MHz}, \mathrm{CDCl}_{3}\right) \delta 171.1(\mathrm{CO}), 152.9$ (C Ar), 144.7 (C Ar), 139.7 (C Ar), $130.5(\mathrm{C} \mathrm{Ar}), 120.7$ (C Ar), $71.4\left(\mathrm{CH}_{2} \mathrm{PEG}\right), 69.4\left(\mathrm{CH}_{2} \mathrm{PEG}\right), 69.4\left(\mathrm{CH}_{2}\right.$ PEG), 69.2 ( $\mathrm{CH}_{2}$ PEG), $69.2\left(\mathrm{CH}_{2}\right.$ PEG), $69.1\left(\mathrm{CH}_{2} \mathrm{PEG}\right), 68.9\left(\mathrm{CH}_{2} \mathrm{PEG}\right), 49.5\left(\mathrm{CH}_{2}\right), 40.4\left(\mathrm{CH}_{2}\right), 38.3$ $\left(\mathrm{CH}_{2}\right), 35.1\left(\mathrm{CH}_{2}\right), 26.6\left(\mathrm{CH}_{2}\right), 26.6\left(\mathrm{CH}_{2}\right), 15.3\left(\mathrm{CH}_{3}\right), 13.4\left(\mathrm{CH}_{3}\right)$. HRMS (ESI $\left.{ }^{+}\right)$, calcd for $\mathrm{C}_{41} \mathrm{H}_{70} \mathrm{BF}_{2} \mathrm{~N}_{4} \mathrm{NaO}_{12}[\mathrm{M}+\mathrm{Na}]^{+} 881.4954$, found 881.4985 . 


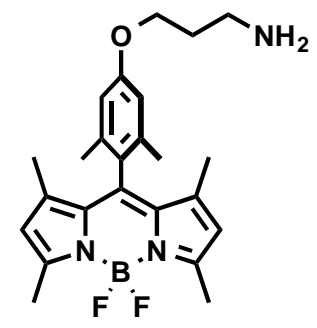

BDP2

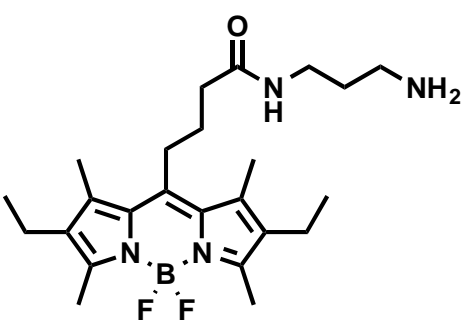

BDP3

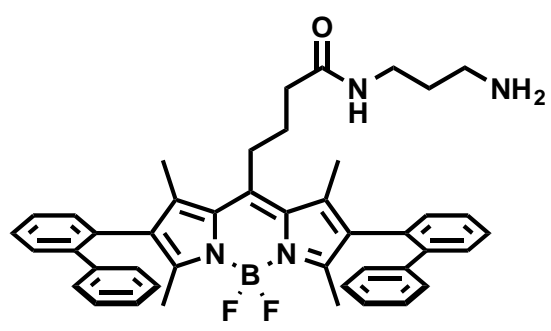

BDP4

\section{Synthesis of BDP2}<smiles></smiles>

2<smiles>NCCCO[AsH3+]</smiles>

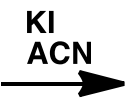

BDP2-N 3

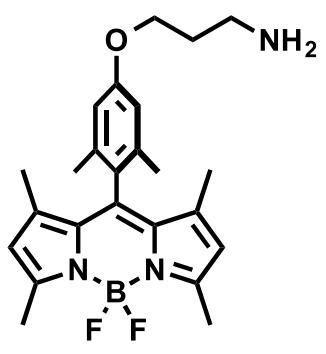

BDP2

2 was synthesized according to a described procedure. ${ }^{3}$

Azidopropane-3-tosyle was synthesized according to a described procedure. ${ }^{4}$

BDP2- $\boldsymbol{N}_{3}$. To a solution of 2 (400 mg, $\left.1.080 \mathrm{mmol}, 1 \mathrm{eq}\right)$ in acetonitrile $(10 \mathrm{~mL})$ was added 1-azidepropane3-tosyle (333 mg, $1.300 \mathrm{mmol}, 1.2 \mathrm{eq})$, potassium carbonate $(300 \mathrm{mg}, 2.174 \mathrm{mmol}, 2 \mathrm{eq})$ and potassium iodide $(36 \mathrm{mg}, 0.217 \mathrm{mmol}, 0.2 \mathrm{eq})$. The reaction was stirred at room temperature and was monitored by TLC (Heptane/EtOAc: 7/3) until completion. The solvents were evaporated under reduced pressure and the product was purified by Flash chromatography on silica gel with solid deposit using Celite ${ }^{\circledR}$ (Heptane/EtOAc : 70/30) to obtain a yellow solid with metallic reflect (406 mg, 83\%). The product was not pure according to NMR and was directly involved to the next step.

BDP2: See Typical procedure for Staudinger azide reduction. $60 \mathrm{mg}$, Yield 64\%. ${ }^{1} \mathrm{H}-\mathrm{NMR}$ (400 MHz, $\left.\mathrm{CDCl}_{3}\right) 6.62$ (s, 2H, CH Ar), 5.89 (s, $\left.2 \mathrm{H}, \mathrm{H}-\beta\right), 3.99\left(\mathrm{t}, 2 \mathrm{H}, \mathrm{CH}_{2}\right), 2.88\left(\mathrm{t}, 2 \mathrm{H}, \mathrm{CH}_{2}\right), 2.48\left(\mathrm{~s}, 6 \mathrm{H}, 2 \mathrm{CH}_{3}\right), 2.02$ (s, 6H, $\left.2 \mathrm{CH}_{3}\right), 1.87\left(\mathrm{~m}, 4 \mathrm{H}, 2 \mathrm{CH}_{2}\right), 2.48\left(\mathrm{~s}, 6 \mathrm{H}, 2 \mathrm{CH}_{3}\right), 1.34\left(\mathrm{~s}, 6 \mathrm{H}, 2 \mathrm{CH}_{3}\right) .{ }^{13} \mathrm{C}-\mathrm{NMR}\left(101 \mathrm{MHz}, \mathrm{CDCl}_{3}\right)$ $\delta$ 159.2 (C Ar), 155.1 (C Ar), 142.3 (C Ar), 141.3 (C Ar), 136.7 (C Ar), 131 (C Ar), 126.6 (C Ar), 120.8 (C Ar), $114.1(\mathrm{C} \mathrm{Ar}), 65.7\left(\mathrm{CH}_{2}\right), 39.1\left(\mathrm{CH}_{2}\right), 32.7\left(\mathrm{CH}_{2}\right), 19.8\left(\mathrm{CH}_{2}\right), 14.6\left(\mathrm{CH}_{3}\right), 13.5\left(\mathrm{CH}_{3}\right)$. HRMS $\left(\mathrm{ESI}^{+}\right)$, calcd for $\mathrm{C}_{24} \mathrm{H}_{30} \mathrm{BF}_{2} \mathrm{~N}_{3} \mathrm{O}[\mathrm{M}+\mathrm{H}]^{+} 426.2450$, found 426.2526 . 


\section{Synthesis of BDP3}

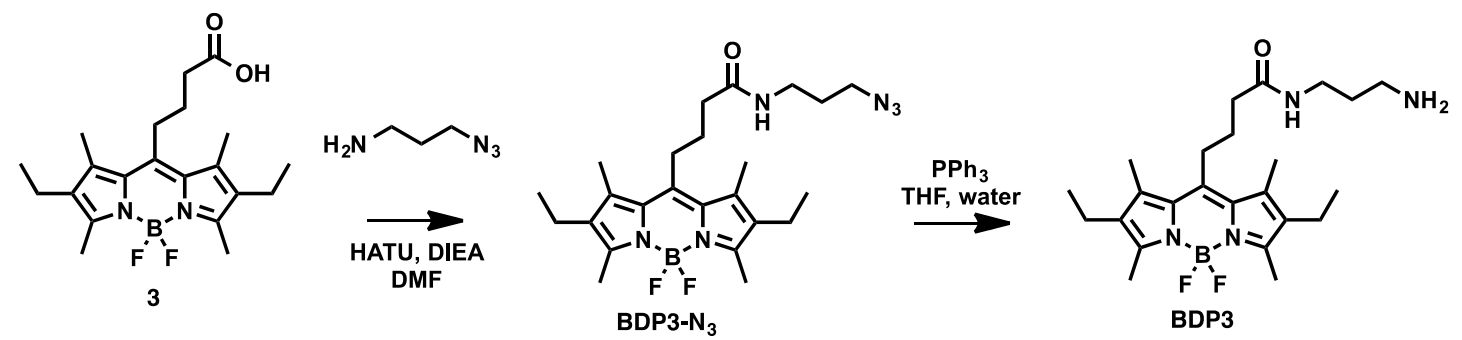

3 was synthesized according to a described procedure. ${ }^{1}$

BDP3- $N_{3}$. To a solution of 3 (500 mg, $\left.1.282 \mathrm{mmol}, 1 \mathrm{eq}\right)$ in DMF (15 mL) was added azidopropylamine (231 mg, $2.308 \mathrm{mmol}, 1.8 \mathrm{eq}$ ), DIEA (496 mg, $3.846 \mathrm{mmol}, 3 \mathrm{eq}$ ) and HATU (585 mg, $1.538 \mathrm{mmol}, 1,2 \mathrm{eq}$ ). The solution was stirred at room temperature for 1 hour. The reaction was monitored by TLC (DCM/Acetone: 99/1) until completion. The DMF was removed under pressure. (DCM/Acetone: 99/1) to obtain a red solid with metallic reflect $(550 \mathrm{mg}, 91 \%)$. ${ }^{1} \mathrm{H}-\mathrm{NMR}\left(400 \mathrm{MHz}, \mathrm{CDCl}_{3}\right) \delta 3.36\left(\mathrm{~m}, 4 \mathrm{H}, 2 \mathrm{CH}_{2}\right)$, $3.06\left(\mathrm{~m}, 2 \mathrm{H}, \mathrm{CH}_{2}\right), 2.49\left(\mathrm{~s}, 6 \mathrm{H}, 2 \mathrm{CH}_{3}\right), 2.40\left(\mathrm{~m}, 2 \mathrm{H}, \mathrm{CH}_{2}\right), 2.36\left(\mathrm{~m}, 2 \mathrm{H}, \mathrm{CH}_{2}\right), 2.34\left(\mathrm{~m}, 8 \mathrm{H}, 4 \mathrm{CH}_{2}\right), 1.97(\mathrm{~m}$, $\left.2 \mathrm{H}, \mathrm{CH}_{2}\right), 1.80\left(\mathrm{~m}, 2 \mathrm{H}, \mathrm{CH}_{2}\right), 1.04\left(\mathrm{t}, 6 \mathrm{H}, 2 \mathrm{CH}_{3}\right) .{ }^{13} \mathrm{C}-\mathrm{NMR}\left(101 \mathrm{MHz}, \mathrm{CDCl}_{3}\right) \delta 170.8(\mathrm{CO}), 151.4(\mathrm{C} \mathrm{Ar})$, $142.6(\mathrm{C} \mathrm{Ar}), 134.8(\mathrm{C} \mathrm{Ar}), 131.8(\mathrm{C} \mathrm{Ar}), 130(\mathrm{C} \mathrm{Ar}), 48.4\left(\mathrm{CH}_{2}\right), 36.3\left(\mathrm{CH}_{2}\right), 35.3\left(\mathrm{CH}_{2}\right), 27.8\left(\mathrm{CH}_{2}\right), 26.6$ $\left(\mathrm{CH}_{2}\right), 26.4\left(\mathrm{CH}_{2}\right), 16.2\left(\mathrm{CH}_{2}\right), 13.8\left(\mathrm{CH}_{3}\right), 12.4\left(\mathrm{CH}_{3}\right), 11.4\left(\mathrm{CH}_{3}\right)$. HRMS (ESI $\left.{ }^{+}\right)$, calcd for $\mathrm{C}_{24} \mathrm{H}_{35} \mathrm{BFN}_{6} \mathrm{O}$ $[\mathrm{M}-\mathrm{F}]^{+}$453.2949, found 453.2936.

BDP3. See Typical procedure for Staudinger azide reduction. $242 \mathrm{mg}$, Yield 47\%. ${ }^{1} \mathrm{H}-\mathrm{NMR}(400 \mathrm{MHz}$, $\left.\mathrm{CDCl}_{3}\right) \delta 3.34\left(\mathrm{~m}, 2 \mathrm{H}, \mathrm{CH}_{2}\right), 3.02\left(\mathrm{~m}, 2 \mathrm{H}, \mathrm{CH}_{2}\right), 2.79\left(\mathrm{~m}, 2 \mathrm{H}, \mathrm{CH}_{2}\right), 2.48\left(\mathrm{~s}, 6 \mathrm{H}, 2 \mathrm{CH}_{3}\right), 2.39\left(\mathrm{~m}, 2 \mathrm{H}, \mathrm{CH}_{2}\right)$, $2.37\left(\mathrm{~m}, 2 \mathrm{H}, \mathrm{CH}_{2}\right), 2.32\left(\mathrm{~m}, 8 \mathrm{H}, 4 \mathrm{CH}_{2}\right), 1.93\left(\mathrm{~m}, 2 \mathrm{H}, \mathrm{CH}_{2}\right), 1.63\left(\mathrm{~m}, 2 \mathrm{H}, \mathrm{CH}_{2}\right), 1.02\left(\mathrm{t}, 6 \mathrm{H}, 2 \mathrm{CH}_{3}\right) .{ }^{13} \mathrm{C}-$ NMR (101 MHZ, $\left.\mathrm{CDCl}_{3}\right) \delta 171.9(\mathrm{CO}), 152.3$ (C Ar), 143.7 (C Ar), 135.8 (C Ar), 132.7 (C Ar), 131 (C Ar), $40\left(\mathrm{CH}_{2}\right), 38.1\left(\mathrm{CH}_{2}\right), 36.5\left(\mathrm{CH}_{2}\right), 31.8\left(\mathrm{CH}_{2}\right), 27.7\left(\mathrm{CH}_{2}\right), 27.5\left(\mathrm{CH}_{2}\right), 17.2\left(\mathrm{CH}_{2}\right), 14.8\left(\mathrm{CH}_{3}\right), 13.3\left(\mathrm{CH}_{3}\right)$, $12.4\left(\mathrm{CH}_{3}\right)$. HRMS $\left(\mathrm{ESI}^{+}\right)$, calcd for $\mathrm{C}_{24} \mathrm{H}_{38} \mathrm{BF}_{2} \mathrm{~N}_{4} \mathrm{O}[\mathrm{M}+\mathrm{H}]^{+} 447.3028$, found 447.3109 .

\section{Synthesis of BDP4}

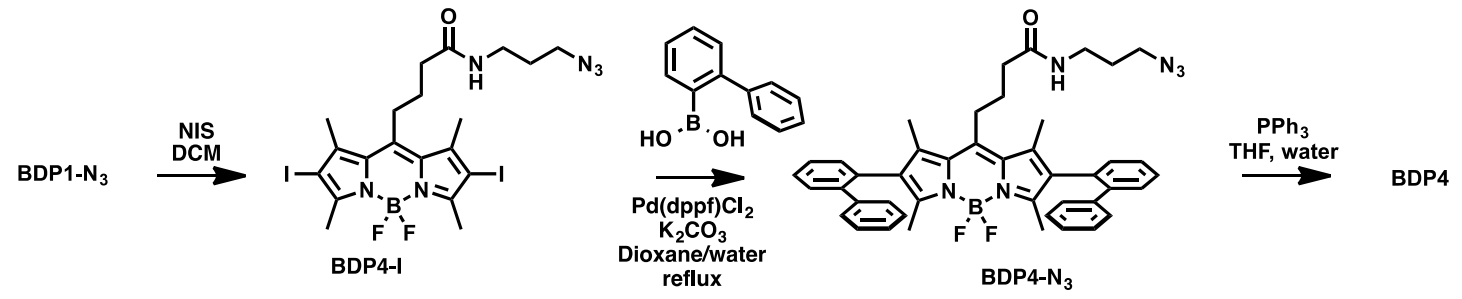

BDP4-I: To a solution of BDP1-N3 $(1.53 \mathrm{~g}, 3.680 \mathrm{mmol}, 1 \mathrm{eq})$ in DCM (100 mL), was added NIodosuccinimide (1.82 g, $8.090 \mathrm{mmol}, 2.2 \mathrm{eq})$. Quickly the solution went from orange to dark pink. The solution was allowed to stir overnight at room temperature. The reaction was monitored by TLC (DCM/Acetone: 99/1). The solvents were evaporated under reduced pressure. The obtained solid was insoluble in most organic solvents and was therefore filtered and washed with $\mathrm{MeOH}$ followed by DCM to obtain $2.03 \mathrm{~g}$ of a red solid. The TLC showed the full conversion of the starting material. The solid was involved in the next step with no further purification.

BDP4-N ${ }_{3}$. To a suspension of BDP4-I $(0.600 \mathrm{~g}, 0.898 \mathrm{mmol}, 1 \mathrm{eq})$ in dioxane $(100 \mathrm{~mL})$ and water $(10 \mathrm{~mL})$ was added biphenyl-2-boronic acid (409 mg, $2.066 \mathrm{mmol}, 2.3 \mathrm{eq}), \mathrm{K}_{2} \mathrm{CO}_{3}(371 \mathrm{mg}, 2.694 \mathrm{mmol}, 3 \mathrm{eq})$ and $\mathrm{Pd}(\mathrm{dppf}) \mathrm{Cl}_{2}(0.650 \mathrm{mg}, 0.090 \mathrm{mmol}, 0.1 \mathrm{eq})$. The reaction was stirred overnight under reflux and was monitored by TLC (Heptane/EtOAc: 5/5). After a night 1 eq. of biphenyl-2-boronic acid (177mg) was added and the solution was stirred overnight at reflux to complete the reaction. The solvents were evaporated and the organic compound was washed with water and extracted with DCM (3 x $100 \mathrm{~mL})$. The crude was purified by flash chromatography (Heptane/EtOAc: $5 / 5)$ to obtain a purple solid (270 $\mathrm{mg}, 42 \%)$. The product 
was obtained as a clean mixture of 2 diastereoisomers. The purity was confirmed by LC-MS. HRMS (ESI ${ }^{+}$), calcd $\mathrm{C}_{44} \mathrm{H}_{43} \mathrm{BF}_{2} \mathrm{~N}_{6} \mathrm{NaO}[\mathrm{M}+\mathrm{Na}]^{+}$743.3457, found 743.3453.

BDP4. To a solution of BDP4-N 3 (150 mg, $0.208 \mathrm{mmol}, 1 \mathrm{eq})$, in THF ( $2 \mathrm{~mL})$ and water $(0.1 \mathrm{~mL})$ was added $\mathrm{PPh}_{3}(82 \mathrm{mg}, 0.312 \mathrm{mmol}, 1.5 \mathrm{eq})$. The solution was stirred overnight at $40^{\circ} \mathrm{C}$. The reaction was monitored by TLC (DCM/MeOH/NEt 3 : 90/9/1) until completion. The solvents were evaporated under reduced pressure and the product was purified by Flash chromatography on silica gel with solid deposit using Celite ${ }^{\circledR}$ (DCM/MeOH/NEt 3 : 90/9/1) to obtain a purple solid with metallic reflect (70 $\left.\mathrm{mg}, 48 \%\right)$. The purity was confirmed by LC-MS. HRMS $\left(\mathrm{ESI}^{+}\right)$, calcd $\mathrm{C}_{44} \mathrm{H}_{45} \mathrm{BF}_{2} \mathrm{~N}_{4} \mathrm{O}[\mathrm{M}+\mathrm{H}]^{+}$694.3654, found 695.3727.

\section{Synthesis of amphiphilic polymers from PMAO}

\section{General consideration}

PMAO is sold with an average $\mathrm{M}_{\mathrm{n}}$ of 30,000-50,000, which makes a polymer with $\sim 100-140$ repeating units per polymer molecule: $\mathrm{M}_{\mathrm{n}}$ is the Molecular weight of the repeating unit A.

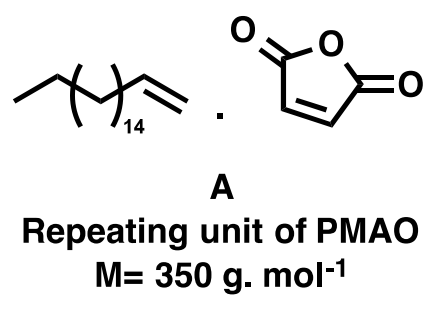

For the synthesis PMAO derivatives, calculation of the molar ratios of reactants was based on repeating monomer units A with a molecular weight of $350 \mathrm{~g} \cdot \mathrm{mol}^{-1}$.

\section{General procedures}

Increasing amount of Jeffamine. In a $15 \mathrm{~mL}$ glass vial equipped with a magnetic bar and placed under an atmosphere of argon was added $20 \mathrm{mg}$ of PMAO (0.057 mmol of repeating units). The polymer was dissolved in $3 \mathrm{~mL}$ of dry and degased DMF under stirring. A volume of Jeffamine-1000 in its stock solution (DMF) was added according to the desired percentage of J-1000 (0 to $100 \%)$. Then, $100 \mu \mathrm{L}$ of DIEA (10 eq) were added to the solution. The solution was allowed to stir overnight at $60^{\circ} \mathrm{C}$ under argon and protected from light. The solution was transferred in a flask and the solvents were evaporated. The crude was dissolved in a DCM:Methanol solution (1:1) and was purified by size exclusion chromatography on LH-20 gel eluted with DCM:Methanol (1:1). The fractions were collected, the solvents were evaporated and the product was dried under high vacuum overnight. The obtained polymers were dissolved in dioxane at a concentration of 2 $\mathrm{mg} / \mathrm{mL}$ and were formulated in milliQ water as described in the "materials and methods" section.

\section{Fluorescent non-PEGylated, half PEGylated and fully PEGylated PMAO polymers}

Non-PEGylated polymer. In a $15 \mathrm{~mL}$ glass vial equipped with a magnetic bar and placed under an atmosphere of argon was added $30 \mathrm{mg}$ of PMAO (0.086 mmol of repeating units). The polymer was dissolved in $3 \mathrm{~mL}$ of dry and degased DMF under stirring. BDP1 $(0.05 \mathrm{eq})$ in its stock solution $(10 \mathrm{mg} / \mathrm{mL}$, DMF) was added. Then, $150 \mu \mathrm{L}$ of DIEA (10 eq) were added to the solution. The solution was allowed to stir overnight at $60^{\circ} \mathrm{C}$ under argon and protected from light. The remaining anhydride functions were then hydrolysed by addition of $100 \mu \mathrm{L}$ of water and the solution was allowed to stir $1 \mathrm{~h}$ at $60^{\circ} \mathrm{C}$. The solution was transferred in a flask and the solvents were evaporated. The crude was dissolved in a DCM:Methanol solution (1:1) and was purified by size exclusion chromatography on LH-20 gel eluted with DCM:Methanol (1:1). The fractions were collected, the solvents were evaporated and the product was dried under high vacuum overnight. The obtained polymer was dissolved in dioxane at a concentration of $2 \mathrm{mg} / \mathrm{mL}$ and was formulated in milliQ water as described in the Materials and Methods section. 
Half-PEGylated polymer. In a $15 \mathrm{~mL}$ glass vial equipped with a magnetic bar and placed under an atmosphere of argon was added $20 \mathrm{mg}$ of PMAO (0.057 mmol of repeating units). The polymer was dissolved in $3 \mathrm{~mL}$ of dry and degased DMF under stirring. BDP1 $(0.05$ eq) in its stock solution $(10 \mathrm{mg} / \mathrm{mL}$, DMF) was added, followed by DIEA (10 eq). Then J-1000 (1.2 eq, stock solution $200 \mathrm{mg} / \mathrm{mL}$, DMF) wax added. The solution was allowed to stir overnight at $60^{\circ} \mathrm{C}$ under argon and protected from light. The solution was transferred in a flask and the solvents were evaporated. The crude was dissolved in a DCM:Methanol solution (1:1) and was purified by size exclusion chromatography on LH-20 gel eluted with DCM:Methanol (1:1). The excess of J-1000 was eliminated and can be monitored by TLC. The fractions were collected, the solvents were evaporated and the product was dried under high vacuum overnight. The obtained polymer was dissolved in dioxane at a concentration of $2 \mathrm{mg} / \mathrm{mL}$ and was formulated in milliQ water as described in the Materials and Methods section.

Fully-PEGylated polymer. In a $15 \mathrm{~mL}$ glass vial equipped with a magnetic bar and placed under an atmosphere of argon was added $20 \mathrm{mg}$ of PMAO ( $0.057 \mathrm{mmol}$ of repeating units). The polymer was dissolved in $3 \mathrm{~mL}$ of dry and degased DMF under stirring. BDP1 $(0.05 \mathrm{eq})$ in its stock solution $(10 \mathrm{mg} / \mathrm{mL}$, DMF), followed by DIEA (10 eq). Then J-1000 (3 eq, stock solution $200 \mathrm{mg} / \mathrm{mL}$, DMF) was added. Then, $100 \mu \mathrm{L}$ of DIEA (10 eq) were added to the solution followed by 2 equivalents of HATU (added as a solid). The solution was allowed to stir at $60^{\circ} \mathrm{C}$ under argon and protected from light. The solution was transferred in a flask and the solvents were evaporated. The crude was dissolved in a DCM:Methanol solution (1:1) and was purified by size exclusion chromatography on LH-20 gel eluted with DCM:Methanol (1:1). The presence of impurities such as HATU derivatives and Jeffamine ${ }^{\circledR}$ were eliminated and can be monitored by TLC. The fractions were collected, the solvents were evaporated and the product was dried under high vacuum overnight. The obtained polymer was dissolved in dioxane at a concentration of $2 \mathrm{mg} / \mathrm{mL}$ and was formulated in milliQ water as described in the Materials and Methods section.

General procedure for increasing amount of fluorophore with full PEGylation. In a $15 \mathrm{~mL}$ glass vial equipped with a magnetic bar and placed under an atmosphere of argon was added $10 \mathrm{mg}$ of PMAO (0.028 mmol of repeating units). The polymer was dissolved in $2 \mathrm{~mL}$ of dry and degased DMF under stirring. Amino Bodipy in a stock solution $(10 \mathrm{mg} / \mathrm{mL}, \mathrm{DMF})$ was added according to the desired percentage of fluorophore on the polymer ( 0 to $50 \%$ ). Then, $50 \mu \mathrm{L}$ of DIEA (10 eq) were added to the solution. After 5 minutes, 3 equivalents of J-1000 were added from the stock solution $(200 \mathrm{mg} / \mathrm{mL}$, DMF) followed by 2 equivalents of HATU (added as a solid). The solution was allowed to stir overnight under argon and protected from light. The solution was transferred in a flask and the solvents were evaporated. The crude was dissolved in a DCM:Methanol solution (1:1) and was purified by size exclusion chromatography on LH-20 gel eluted with DCM:Methanol (1:1). The coloured fraction is the amphiphilic polymer. The presence of impurities such as HATU derivatives and Jeffamine ${ }^{\circledR}$ were eliminated and can be monitored by TLC. The fractions were collected, the solvents were evaporated and the product was dried under high vacuum overnight. The obtained polymer was dissolved in dioxane at a concentration of $2 \mathrm{mg} / \mathrm{mL}$ and was formulated in milliQ water as described in the Materials and Methods section. 


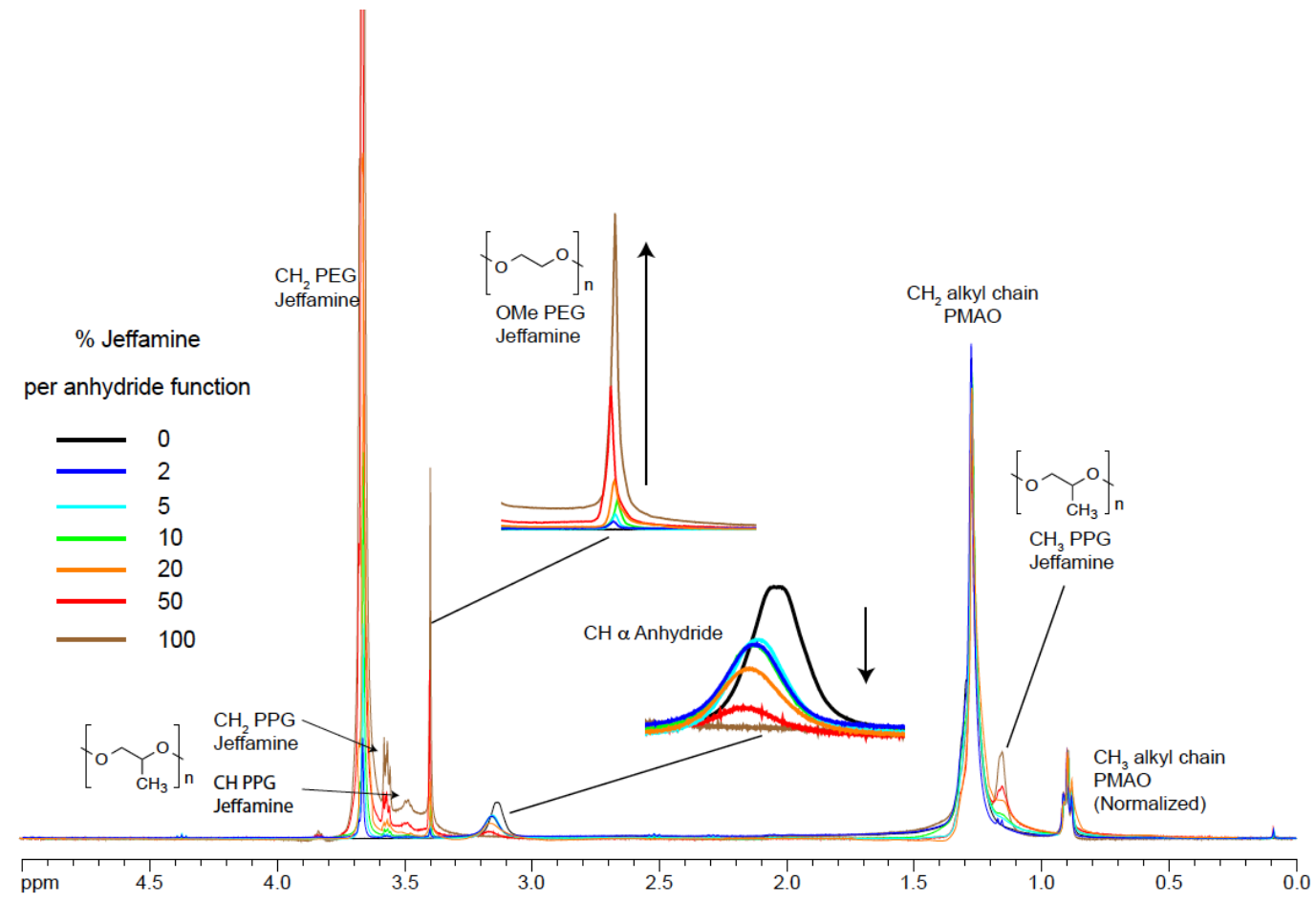

Figure S1. NMR spectra of PMAO reacted with increasing amount of Jeffamine-1000 (400 MHz, $\mathrm{CDCl}_{3}$ ). $0 \%$ Jeffamine is PMAO polymer with no modification.

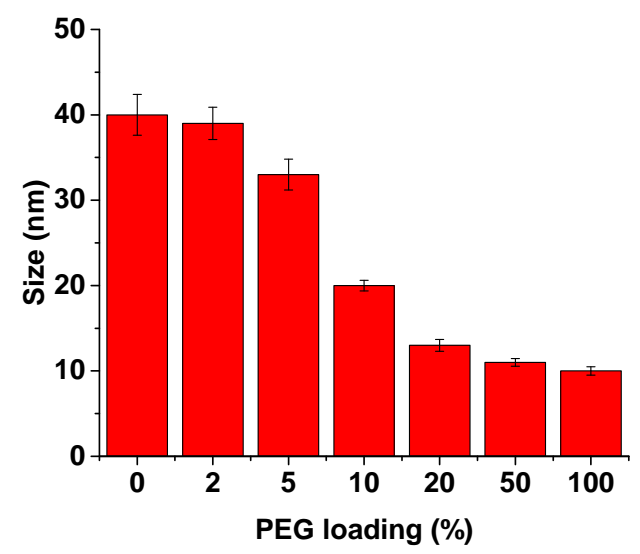

Figure S2. Size of NPs obtained from polymers with increasing PEGylation rate. The sizes were assessed by DLS measurements of three independent formulations. For 0\% PEG loading, nonmodified PMAO was directly used.

\section{Determination of PEGylation yield by ${ }^{1} \mathrm{H}-\mathrm{NMR}$.}

The first signal at $0.8-0.9 \mathrm{ppm}$, corresponding to the $\mathrm{CH}_{3}$ of the aliphatic chain of PMAO, was integrated as 3 protons. The region from 2 to $5 \mathrm{ppm}$ was then integrated as the signals of the $\mathrm{CH}_{2} \mathrm{O}$, CHN of Jeffamine-1000 (J-1000), in this region no PMAO signal is displayed (see control NMR of $\mathrm{J}-1000$ and PMAO). $\mathrm{J}-1000$ is sold as $\mathrm{H}_{2} \mathrm{~N}-(\mathrm{PO})_{3}-(\mathrm{EO})_{19}-\mathrm{OMe}$ (where $\mathrm{PO}$ is propylene glycol and $\mathrm{EO}$ is ethylene glycol) has 88 protons in the region 2 to $5 \mathrm{ppm}$. For the fully PEGylated polymer the baseline of the PMAO's $\mathrm{CH}_{3}$ had to be corrected due to overlap with the $\mathrm{CH}_{3}$ propyleneglycol group of J1000. The PEGylation yield was calculated considering that $5 \%$ of the anhydride was used for introducing BODIPY and as the ratio of the integration value between 2 to $5 \mathrm{ppm}$ region and the 
theoretical value. The results gave a PEGylation yield of $96 \%$ for the half PEGylation of and a PEGylation yield of $88 \%$ for the full PEGylation.
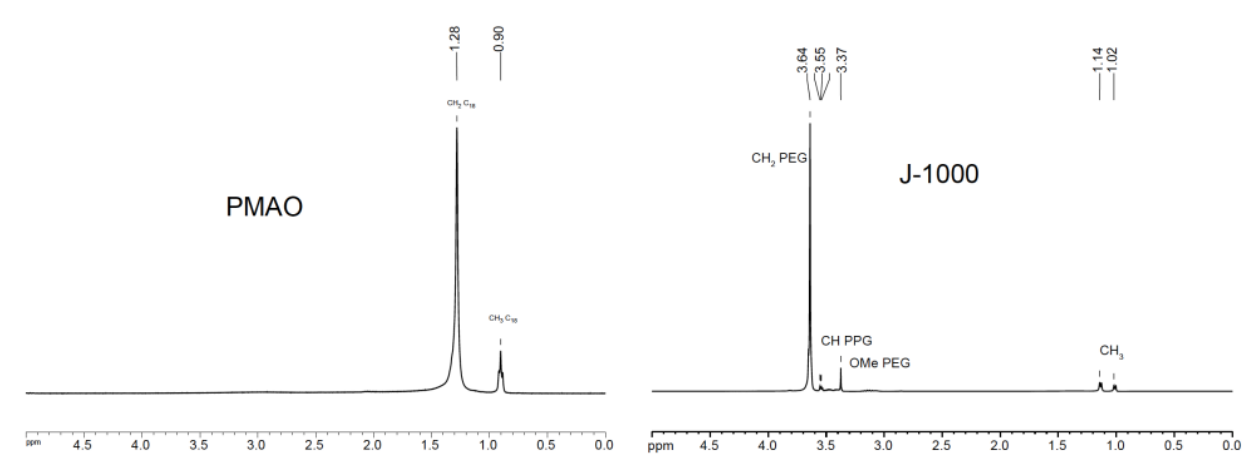

${ }^{1} \mathrm{H}-\mathrm{NMR}$ of PMAO (left) and J-1000 (right) in $\mathrm{CDCl}_{3}$.

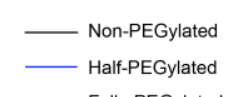

_ Fully-PEGylated

BODIPY CH $\beta$

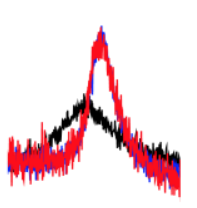

$\begin{array}{lll}6.10 & 6.05 & 6.00\end{array}$

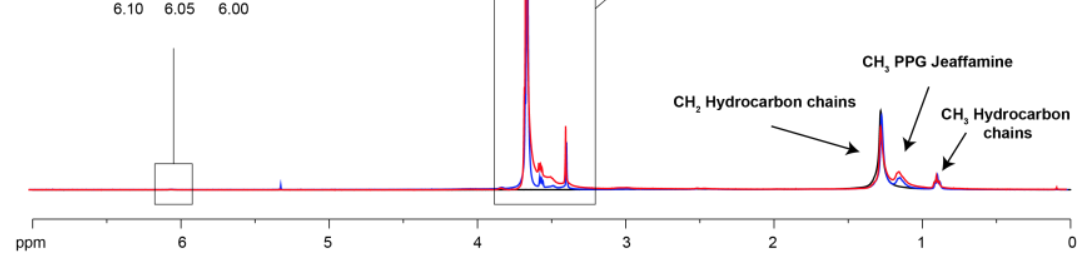

Figure S3. NMR spectra of fluorescent PMAO polymers reacted with increasing amount of Jeffamine-1000 $\left(400 \mathrm{MHz}, \mathrm{CDCl}_{3}\right)$. 

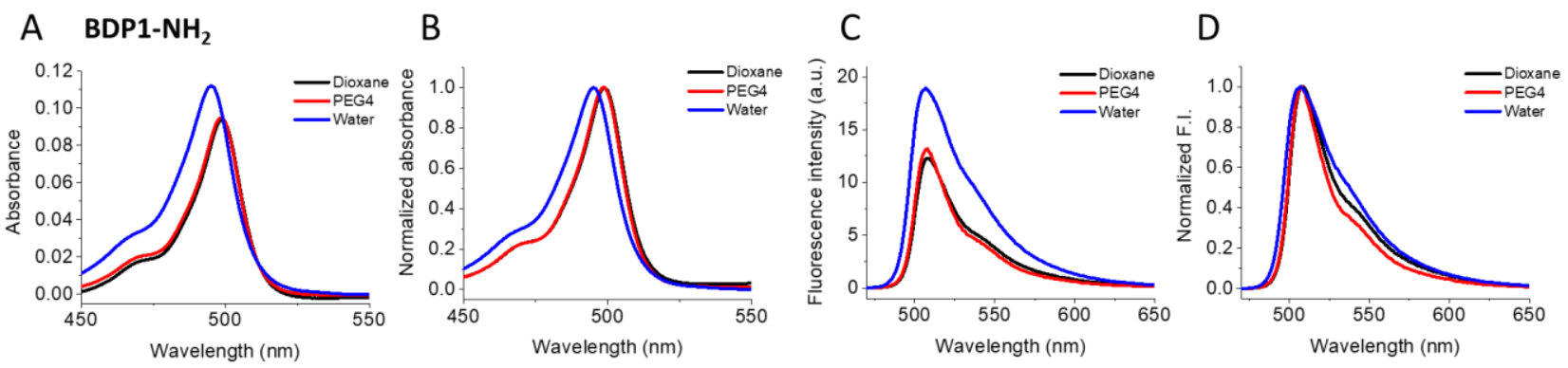

\section{E fully PEGylated, 5\% BDP1 F}

G
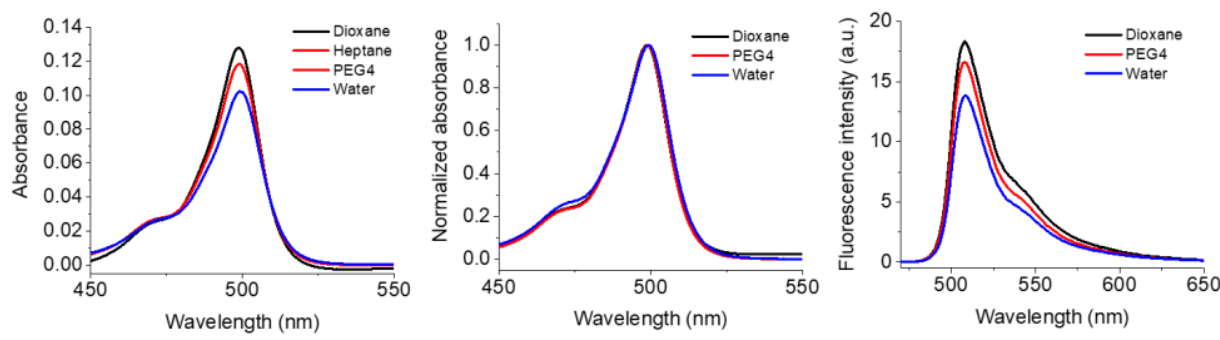

$\mathrm{H}$

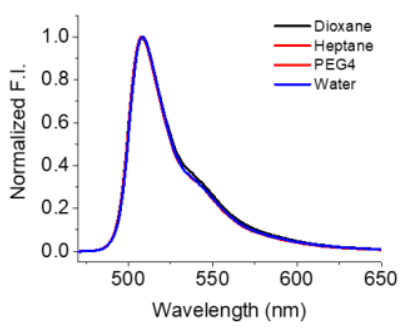

Figure S4. Absorption (A,B,E,F) and fluorescence (C,D,G,H) spectra of free BDP1-amino derivative (BDP1-NH2) and fully PEGylated PMAO polymer with $5 \mathrm{~mol} \%$ BDP1 in different solvents. Spectra $(\mathrm{B}, \mathrm{D}, \mathrm{F}, \mathrm{H})$ are normalized. Dye concentration was systematically $1 \mu \mathrm{M}$. Excitation wavelength was $460 \mathrm{~nm}$. 


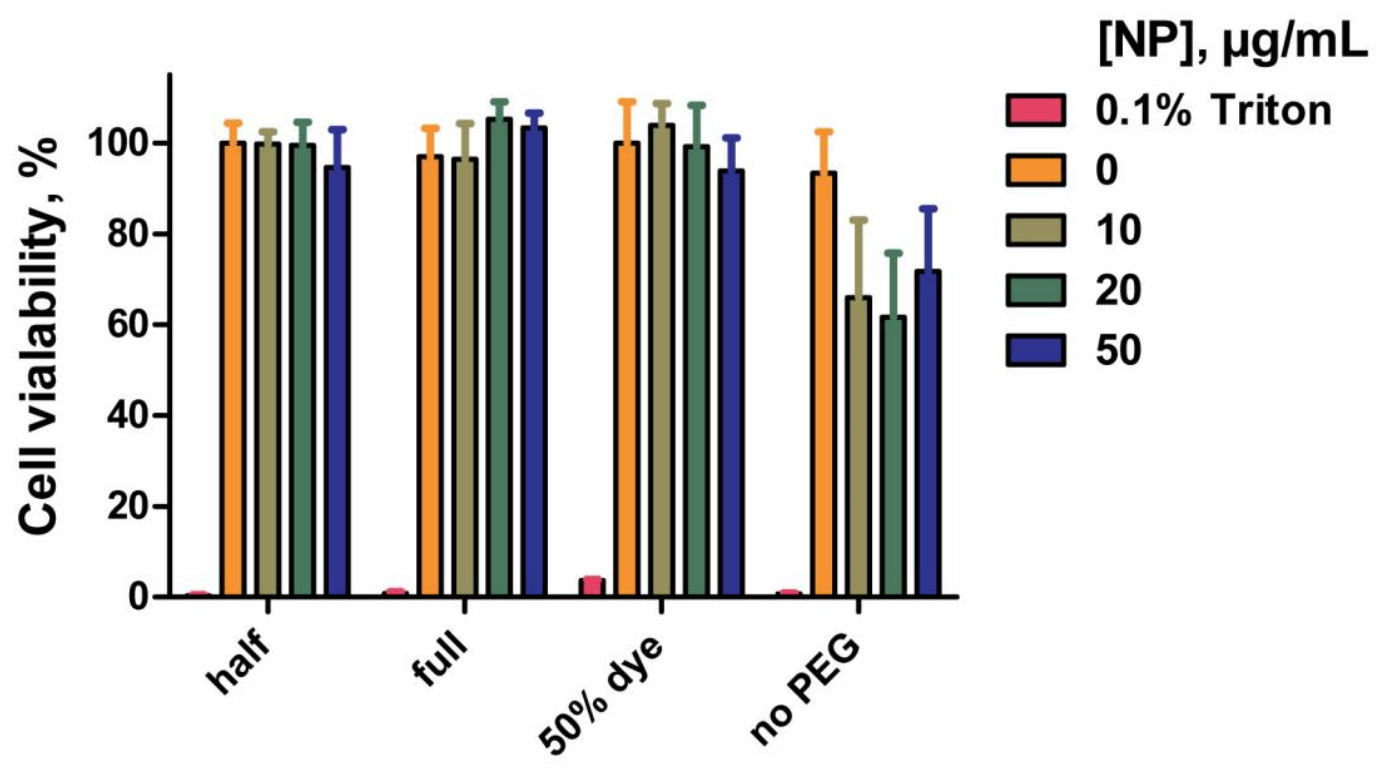

Figire S5. Cytotoxicity assay of NPs after $24 \mathrm{~h}$ incubation quantified by MTT assays. «50\% dye » correponds to NPs with 50 mol\% BDP4. 0.1\% Triton X100 is a positive control. 
A
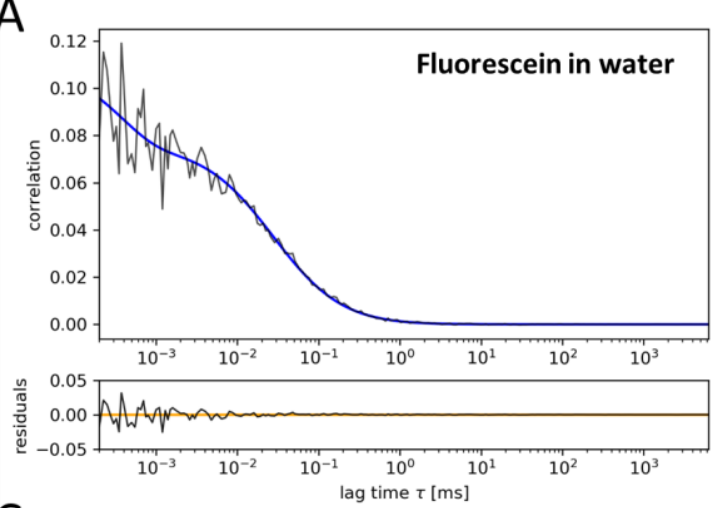

C

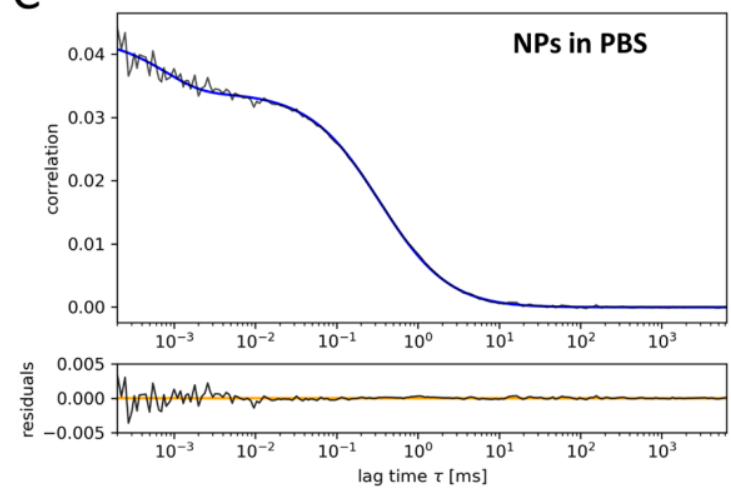

B
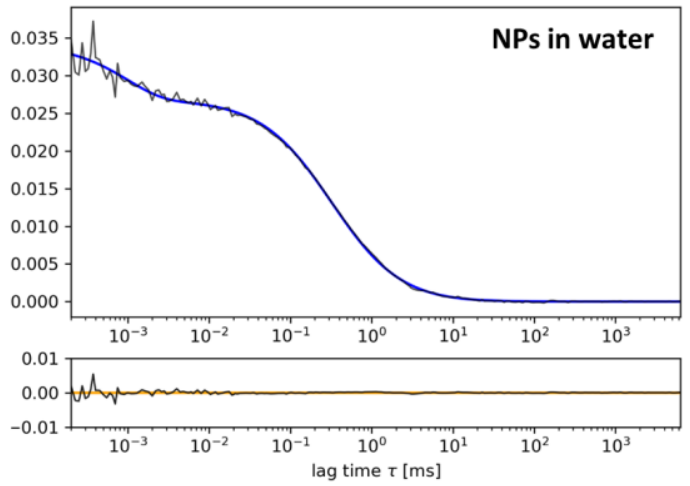

D

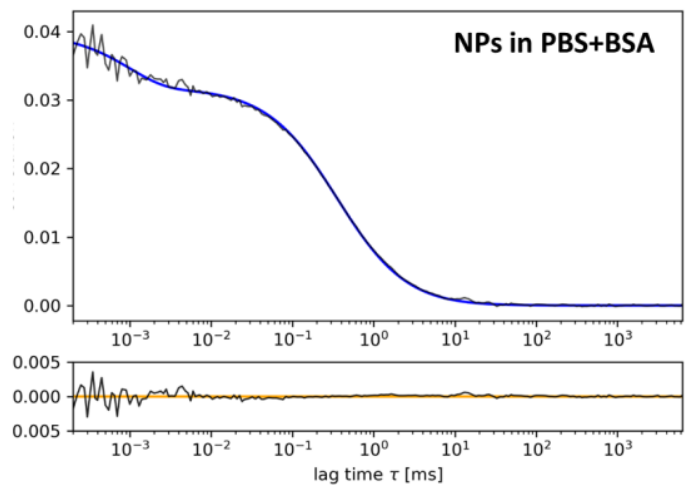

Figure S6. Examples of FCS correlation curves (black) for fluorescein $(50 \mathrm{nM})(\mathrm{A})$ and fully PEGylated NPs with $5 \mathrm{~mol} \%$ of BDP1 (140 nM polymer) in water (B), PBS (C) and PBS with $10 \mu \mathrm{M}$ BSA (D), and corresponding fits (blue, 3D model with a triplet) using PyCorrFit software. For each condition, a single curve is shown out of 10 acquired in total. 


\section{Theoretical calculation for the size of a fully PEGylated monomolecular NP:}

For this calculation we considered the higher molecular weight of PMAO $\left(50,000 \mathrm{~g}^{\mathrm{m}} \mathrm{mol}^{-1}\right)$ which corresponds to -140 repeating units per polymer chain (see above: general considerations).

The molecular weight of the fully PEGylated NP with 5\% BODIPY is calculated as followed:
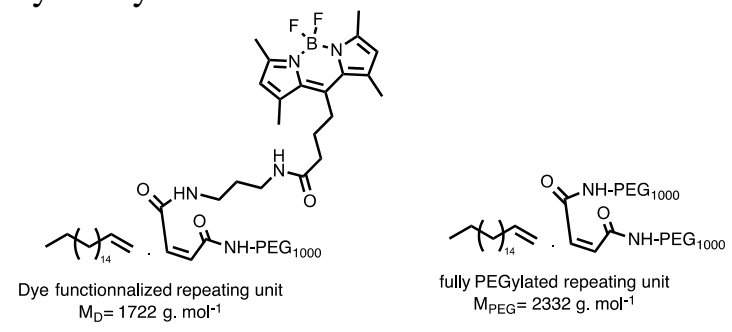

- Molecular weight of the average repeating unit $\left(\mathrm{M}_{\mathrm{R}}\right)$ :

$\mathrm{M}_{\mathrm{R}}=\mathrm{M}_{\mathrm{D}} \times 0.05+\mathrm{M}_{\mathrm{PEG}} \times 0.95=2301 \mathrm{~g} \cdot \mathrm{mol}^{-1}$

- Molecular weight of a single polymer molecule $\left(\mathrm{M}_{\mathrm{P}}\right)$ is:

$M_{P}=M_{R} \times$ number of repeating units $=2301 \times 140=322,210 \mathrm{~g} \cdot \mathrm{mol}^{-1}$

- The mass of a single polymer molecule $\left(\mathrm{m}_{\mathrm{P}}\right)$ is:

$\mathrm{m}_{\mathrm{P}}=1 / N_{\mathrm{A}} \times \mathrm{M}_{\mathrm{P}}=6,02210^{-23} \times 322,210=53,50510^{-19} \mathrm{~g}=5.3510^{-22} \mathrm{Kg}$

Where $N_{\mathrm{A}}$ is the Avogadro number.

The volume of the monomolecular NP $\left(\mathrm{V}_{\mathrm{P}}\right)$ is calculated as follow considering a sphere composed of a matter with a density (d) equal to $1000 \mathrm{Kg} / \mathrm{m}^{3}$ :

$\mathrm{V}_{\mathrm{P}}=\mathrm{m}_{\mathrm{P}} / \mathrm{d}=5.3510^{-22} / 1000=5.3510^{-25} \mathrm{~m}^{3}=535 \mathrm{~nm}^{3}$

- The radius of the NP $(\mathrm{R})$ is:

$\mathrm{R}=\left(3 \mathrm{~V}_{\mathrm{P}} / 4 \pi\right)^{1 / 3}=5.03 \mathrm{~nm}$

- $\quad$ Diameter of the NP (D) is:

$\mathrm{D}=2 \times \mathrm{R}=5.03 \times 2=\underline{10.1 \mathrm{~nm}}$

Considering the lowest molecular weight $(\mathrm{Mn})$ of PMAO indicated by the provider $\left(30,000 \mathrm{~g} \cdot \mathrm{mol}^{-1}\right)$, the same calculation above yields a theoretical particle size of $\underline{8.5 \mathrm{~nm}}$. 
A

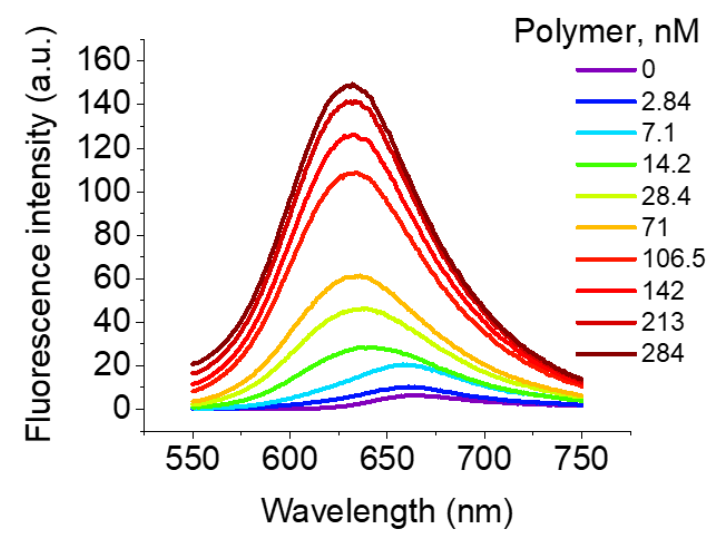

C

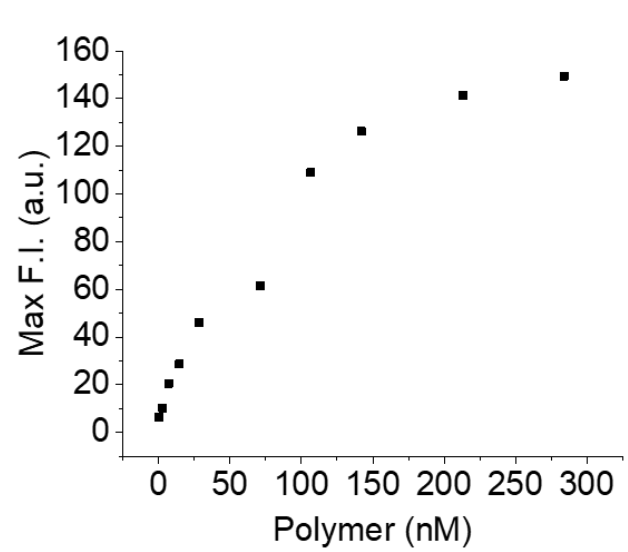

B
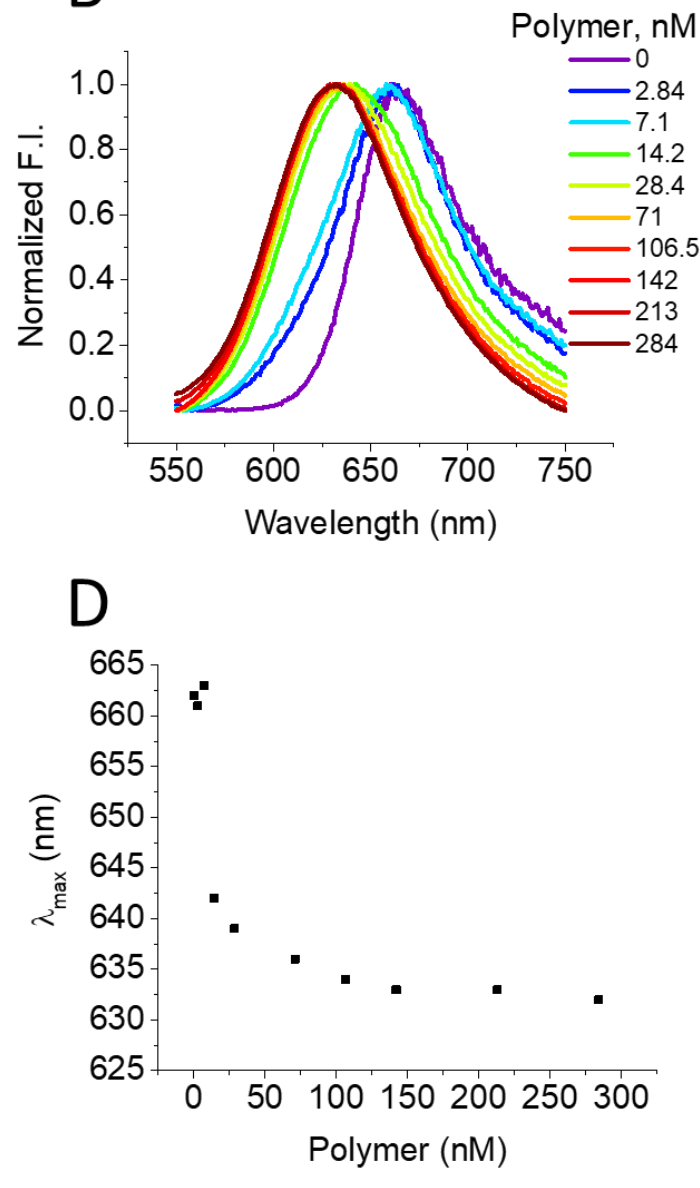

Figure S7. Fluorescence spectra (A) and normalized spectra (B) of Nile Red (200 nM) at increasing concentration of BDP1 NPs (5 mol\%). Concentration of polymer is used. (C,D) Corresponding changes in the fluorescence intensity at the maximum (C) and position of the maximum (D). Excitation wavelength was $540 \mathrm{~nm}$. 

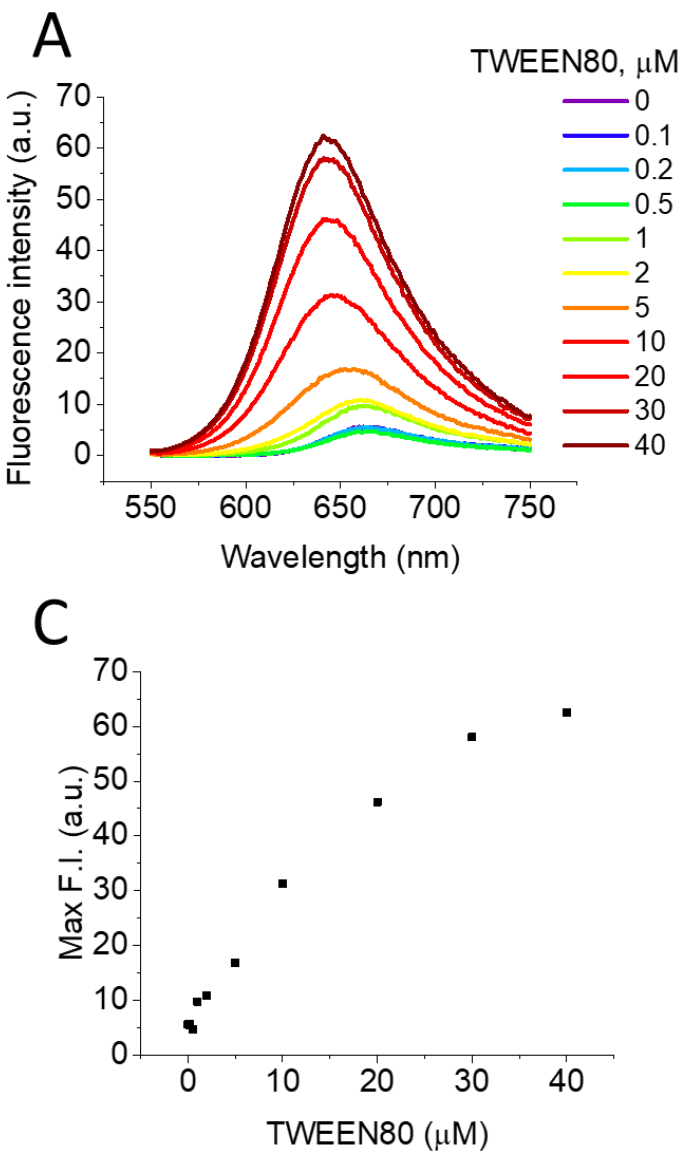

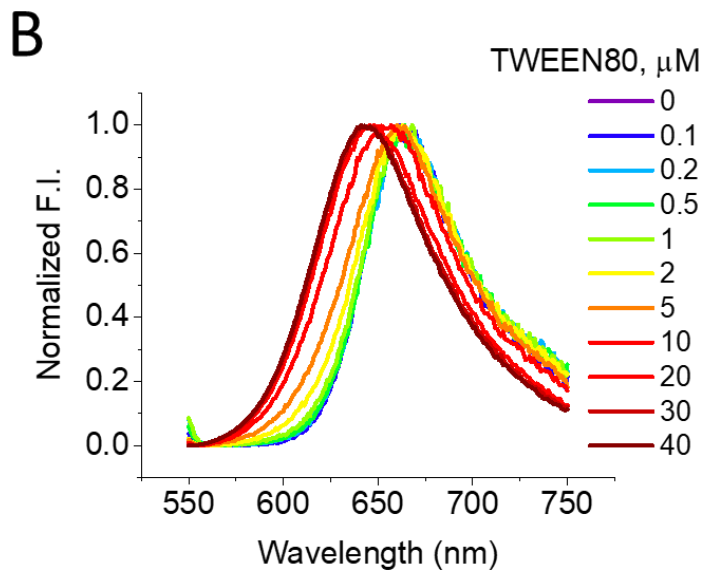

D

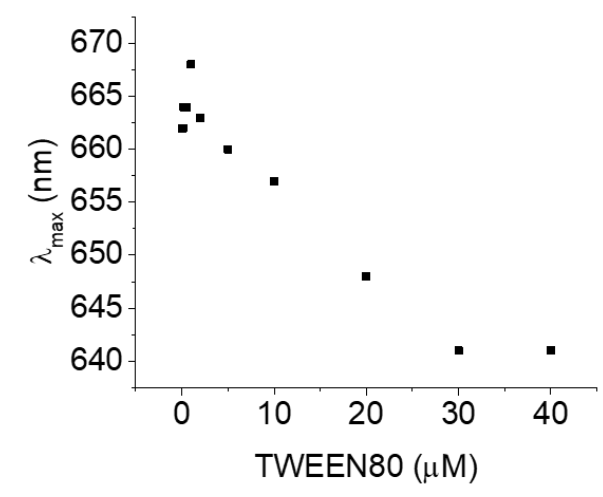

Figure S8. Fluorescence spectra (A) and normalized spectra (B) of Nile Red (200 nM) at increasing concentration of Tween 80. (C,D) Corresponding changes in the fluorescence intensity at the maximum (C) and position of the maximum (D). Excitation wavelength was $540 \mathrm{~nm}$.

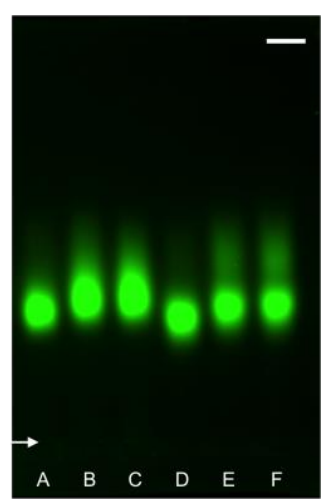

Figure S9. Agarose gel $(0.5 \%)$ electrophoresis of NPs with 5 mol\% BDP1 fluorophore displayed: at the interface (A) in the core (B) and in the PEG shell (C) $(0.2 \mu \mathrm{g}$ per well). D, E and F are the same in the presence of $5 \mu \mathrm{M}$ BSA. The white arrow indicates the level of the wells. Scale bar is $0.5 \mathrm{~cm}$. 

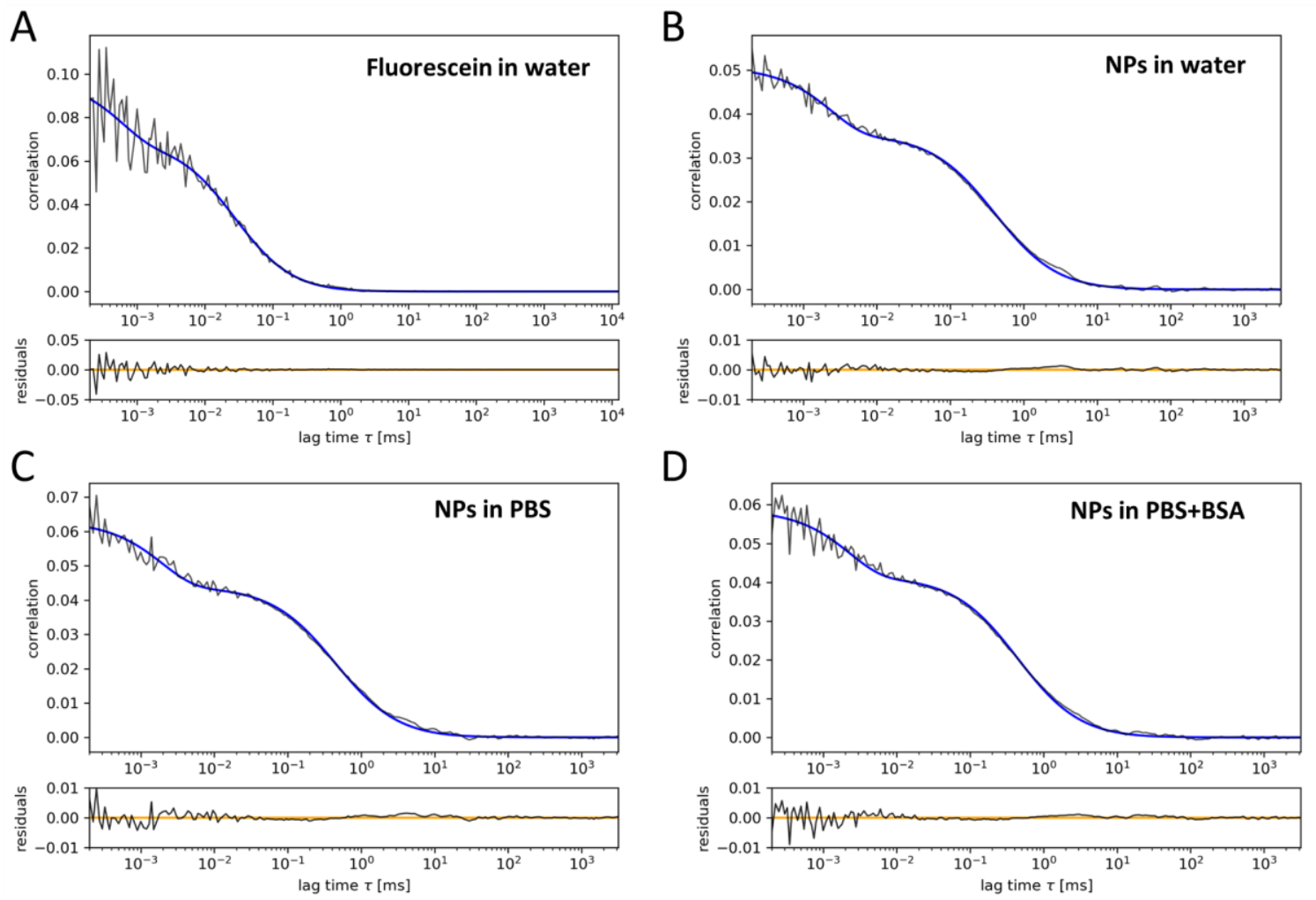

Figure S10. Examples of FCS correlation curves (black) for fluorescein (50 nM) (A) and fully PEGylated NPs with $5 \mathrm{~mol} \%$ of BDP4 (140 nM polymer) in water (B), PBS (C) and PBS with $10 \mu \mathrm{M}$ BSA (D), and corresponding fits (blue, 3D model with a triplet) using PyCorrFit software. For each condition, a single curve is shown out of $\geq 15$ acquired in total.

Table S1. Physicochemical properties of the PMAO NPs with 5 mol\% BDP4, obtained by FCS measurements.

\begin{tabular}{|l|l|l|l|l|}
\hline Conditions & $\begin{array}{l}\text { Size } \\
(\mathrm{nm})^{\mathrm{a}}\end{array}$ & $\begin{array}{l}{[\text { Particles }]} \\
(\mathrm{nM})\end{array}$ & $\begin{array}{l}\text { Number of } \\
\text { polymer per NP }^{\mathrm{b}}\end{array}$ & $\begin{array}{l}\text { Relative } \\
\text { Brightness }^{\mathrm{c}}\end{array}$ \\
\hline Water & 16.8 & 98.2 & 1.42 & 4.06 \\
\hline PBS & 18.4 & 78.2 & 1.79 & 4.10 \\
\hline $\begin{array}{l}10 \mu \mathrm{M} \text { BSA in } \\
\text { PBS }\end{array}$ & 17.0 & 90.0 & 1.56 & 3.84 \\
\hline
\end{tabular}

${ }^{a}$ Obtained considering the reference (fluorescein) being $1 \mathrm{~nm} .{ }^{\mathrm{b}}$ The polymer concentration was adjusted to $1 \mu \mathrm{M}$ fluorophore (corresponding to $140 \mathrm{nM}$ polymer concentration). ${ }^{\mathrm{c}}$ Relative Brightness compared to the reference (fluorescein). The values were corrected according to the molar extinction coefficient values at the excitation wavelength $(488 \mathrm{~nm})$. 

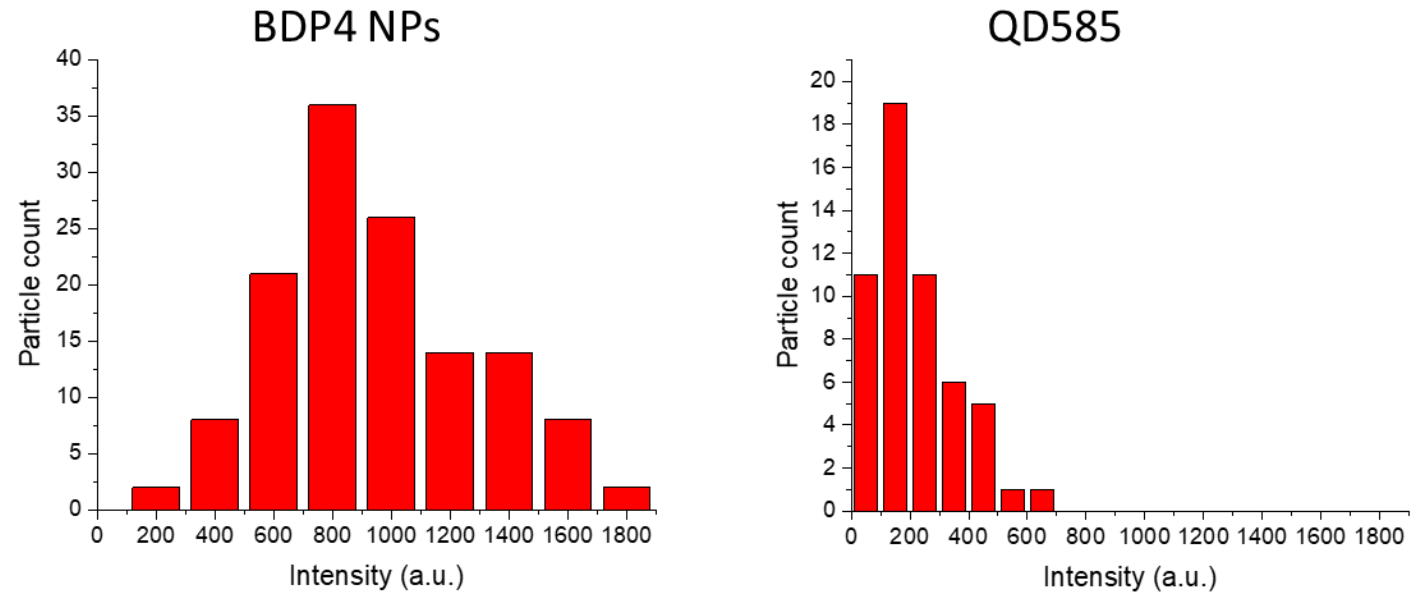

Figure S11. Histogram of intensity distribution of fully PEGylated PMAO NPs with 50 mol\% of BDP4 and QDots-585 at the same measurement conditions using single-particle fluorescence microscopy (TIRF, $\lambda E x=532 \mathrm{~nm}$, power density: $3 \mathrm{~W} \mathrm{~cm}^{-2}$ ). Integration time was $20 \times 100 \mathrm{~ms} .150$ and 50 particles were analyzed for BDP4 NPs and QDots-585, respectively. 


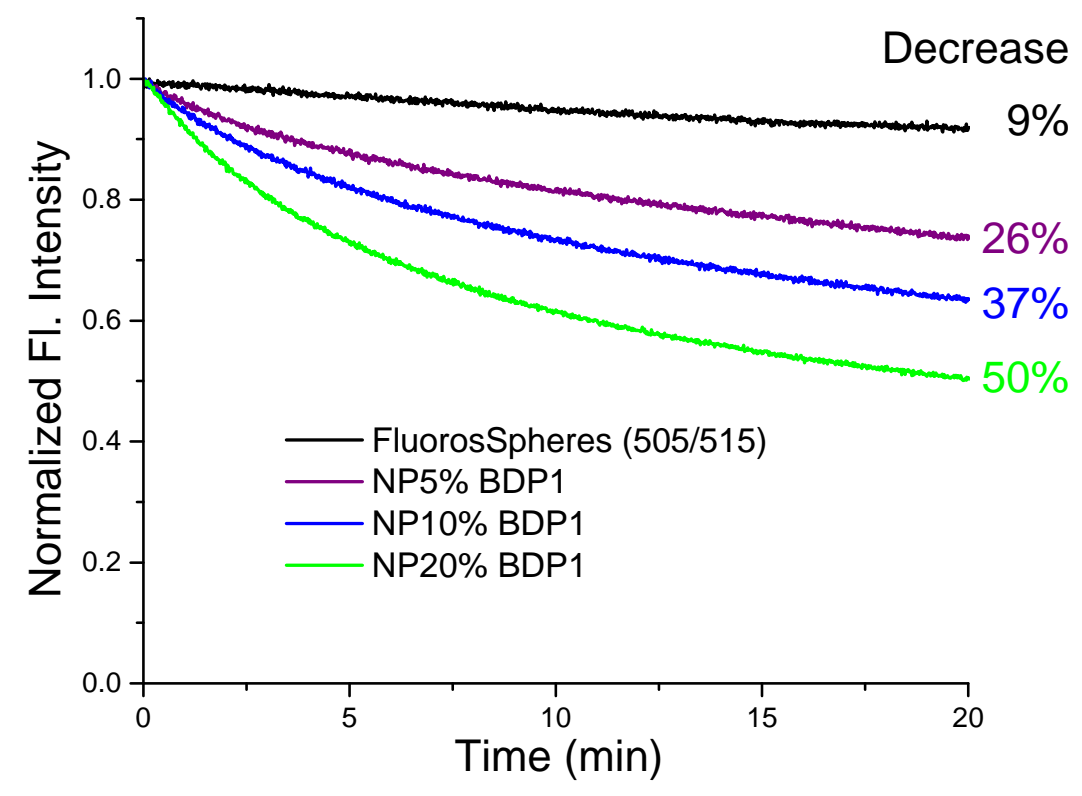

Figure S12. Comparison of the photostability of NPs at different BDP1 loading and FluoroSpheres $^{\mathrm{TM}}$ (505/515). Irradiation wavelength was $486 \mathrm{~nm}$.

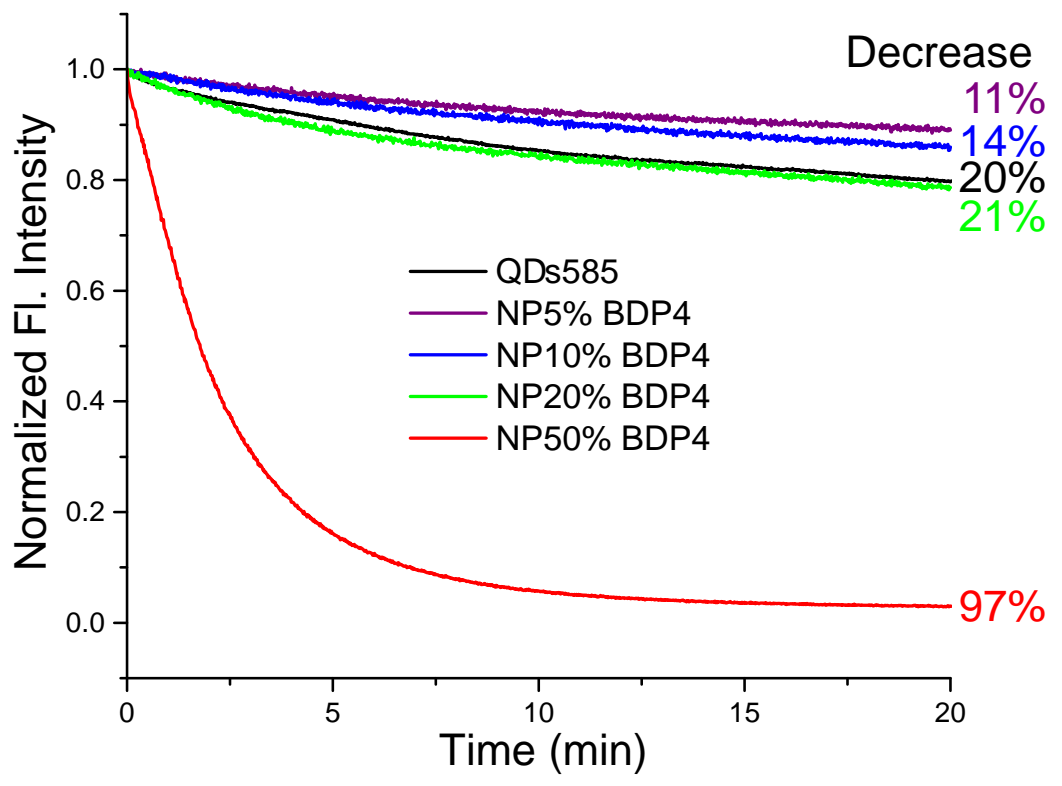

Figure S13. Comparison of the photostability of NPs at different BDP4 loading and QDots-585. Irradiation wavelength was $486 \mathrm{~nm}$. 

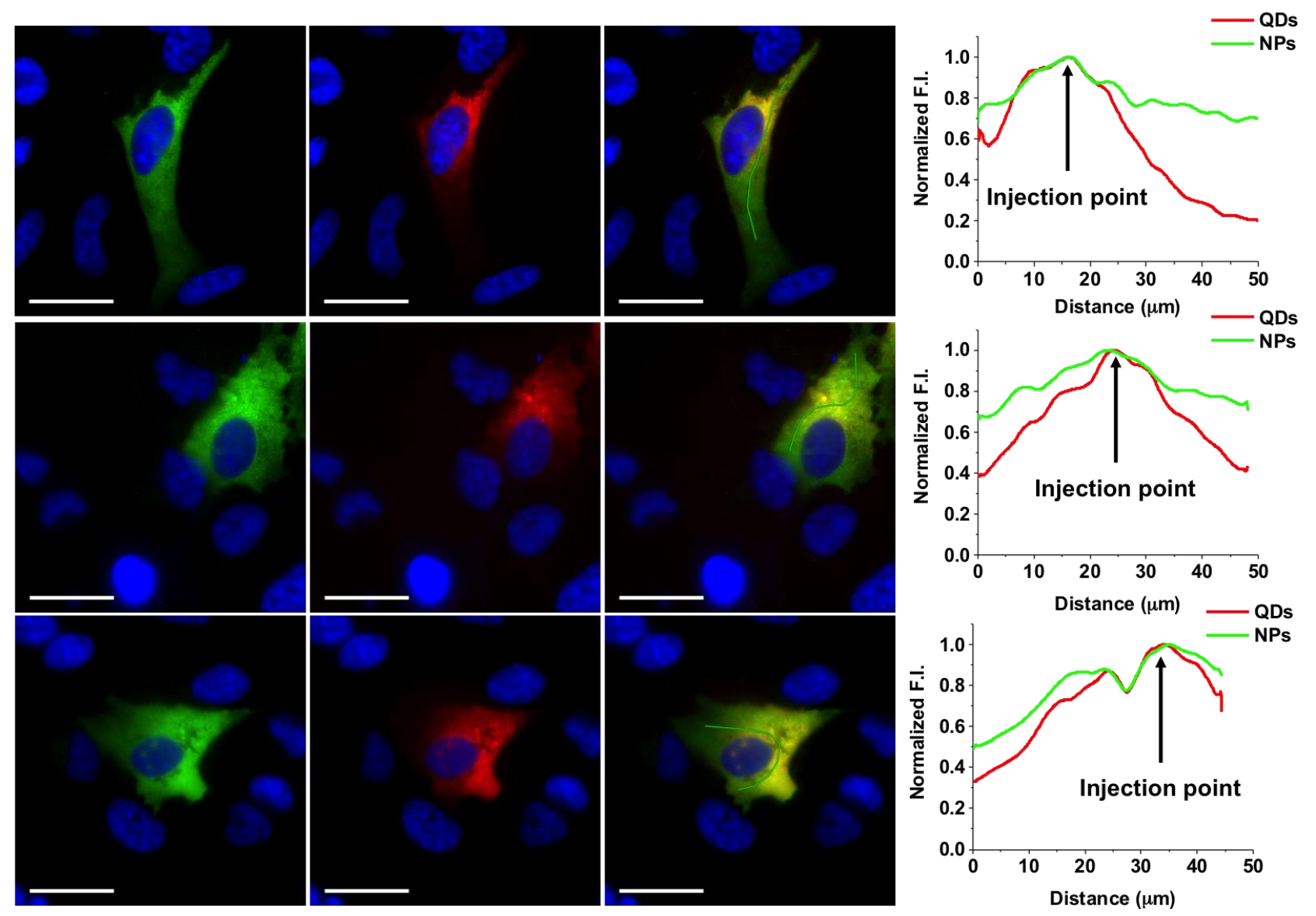

Figure S14. Supplementary fluorescence images of co-injected NPs (green) and quantum dots QDot-655 (red) in three different cells (see Figure 8 caption for details). 
NMR and mass spectra

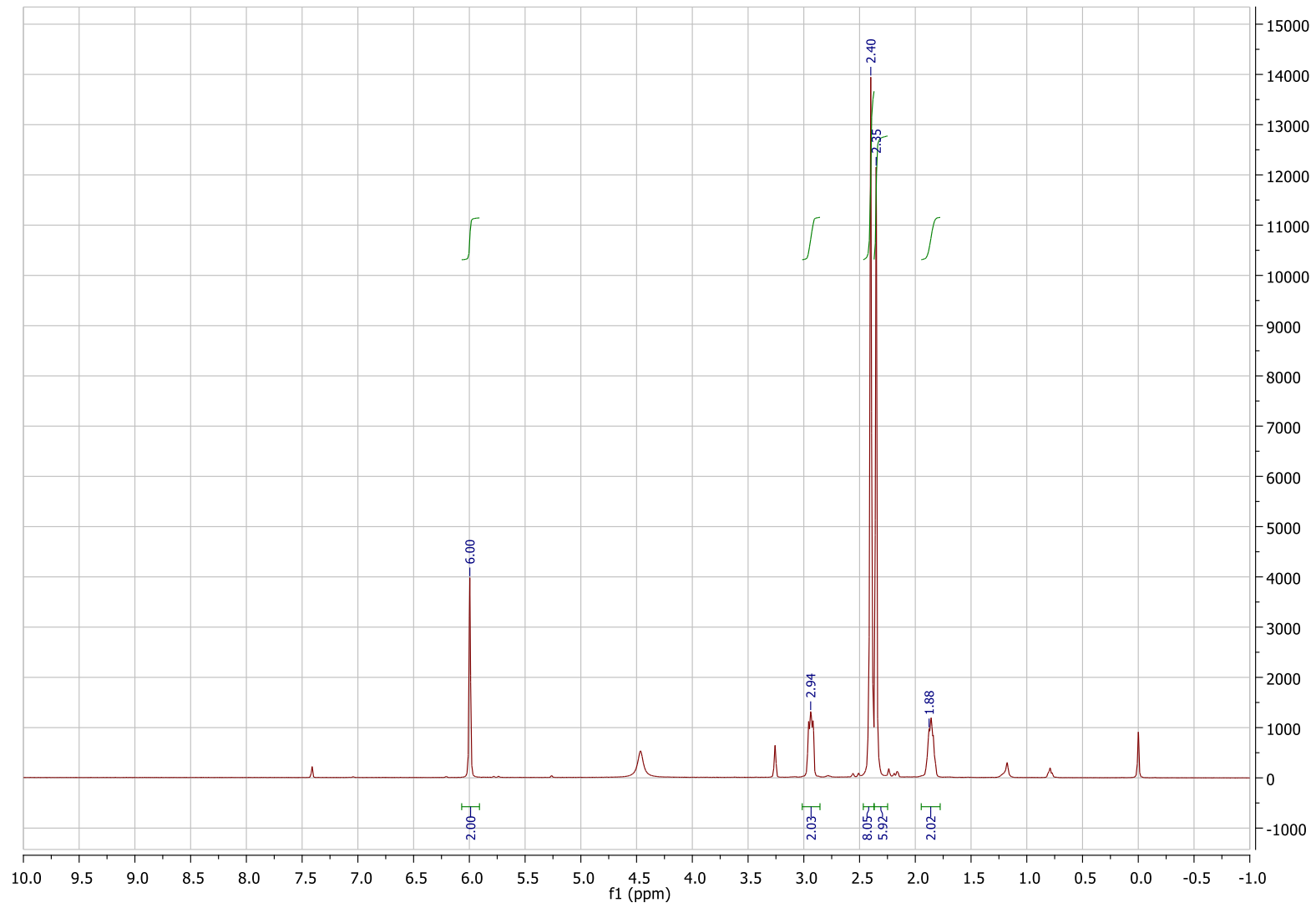

${ }^{1} \mathrm{H}$ spectrum of $\mathbf{1}$

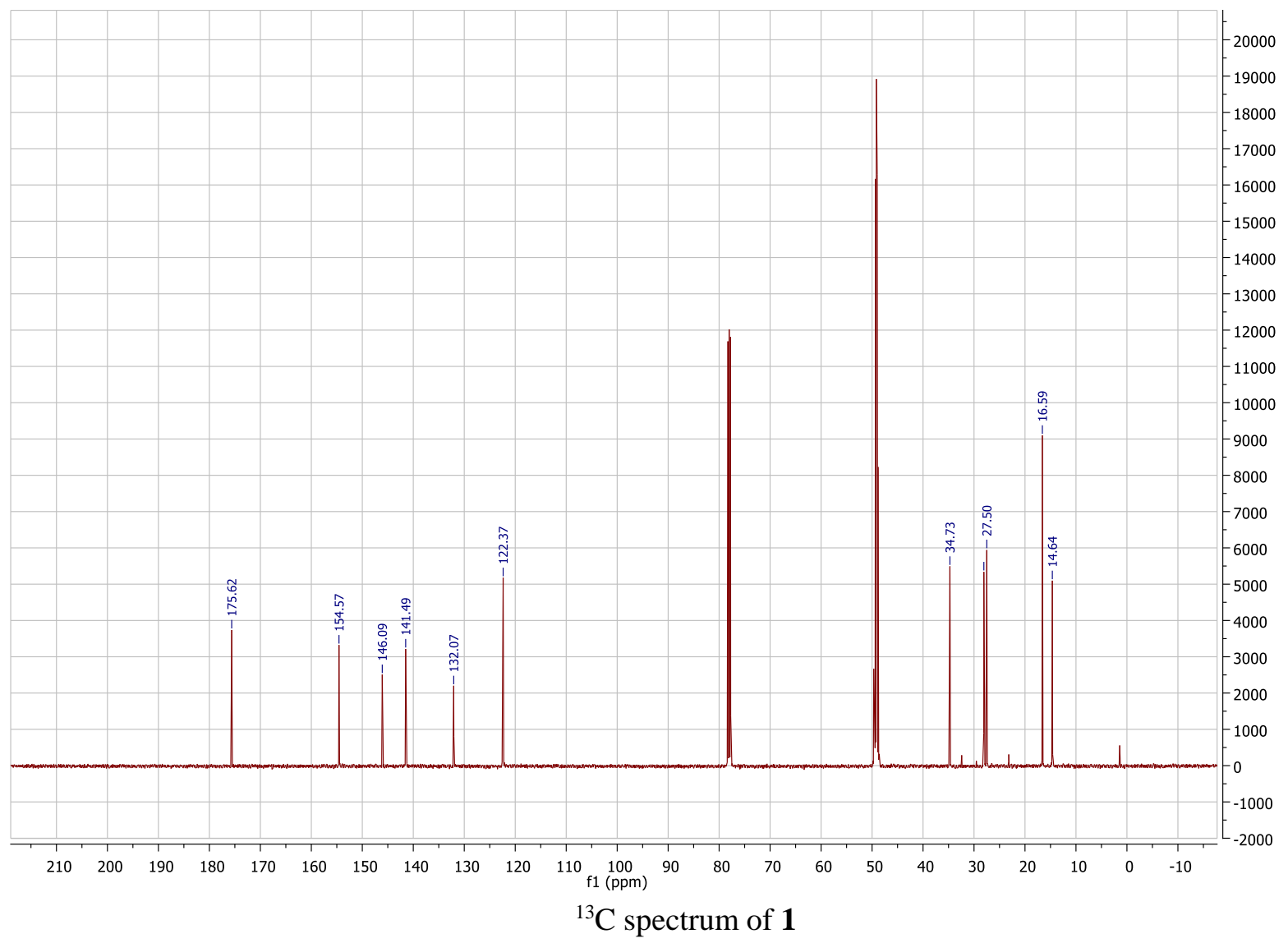




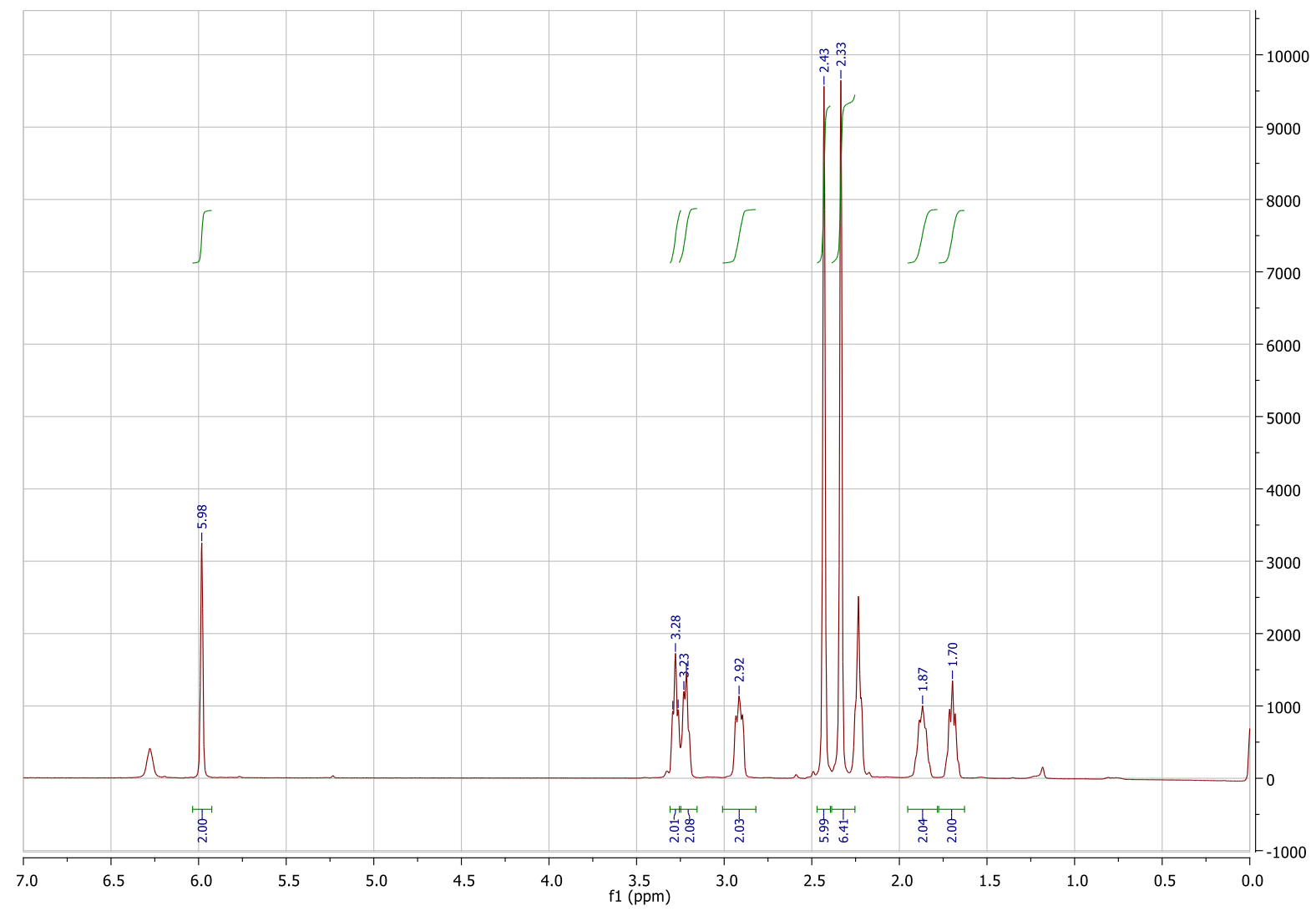

${ }^{1} \mathrm{H}$ spectrum of BDP1-N $\mathbf{N}_{3}$

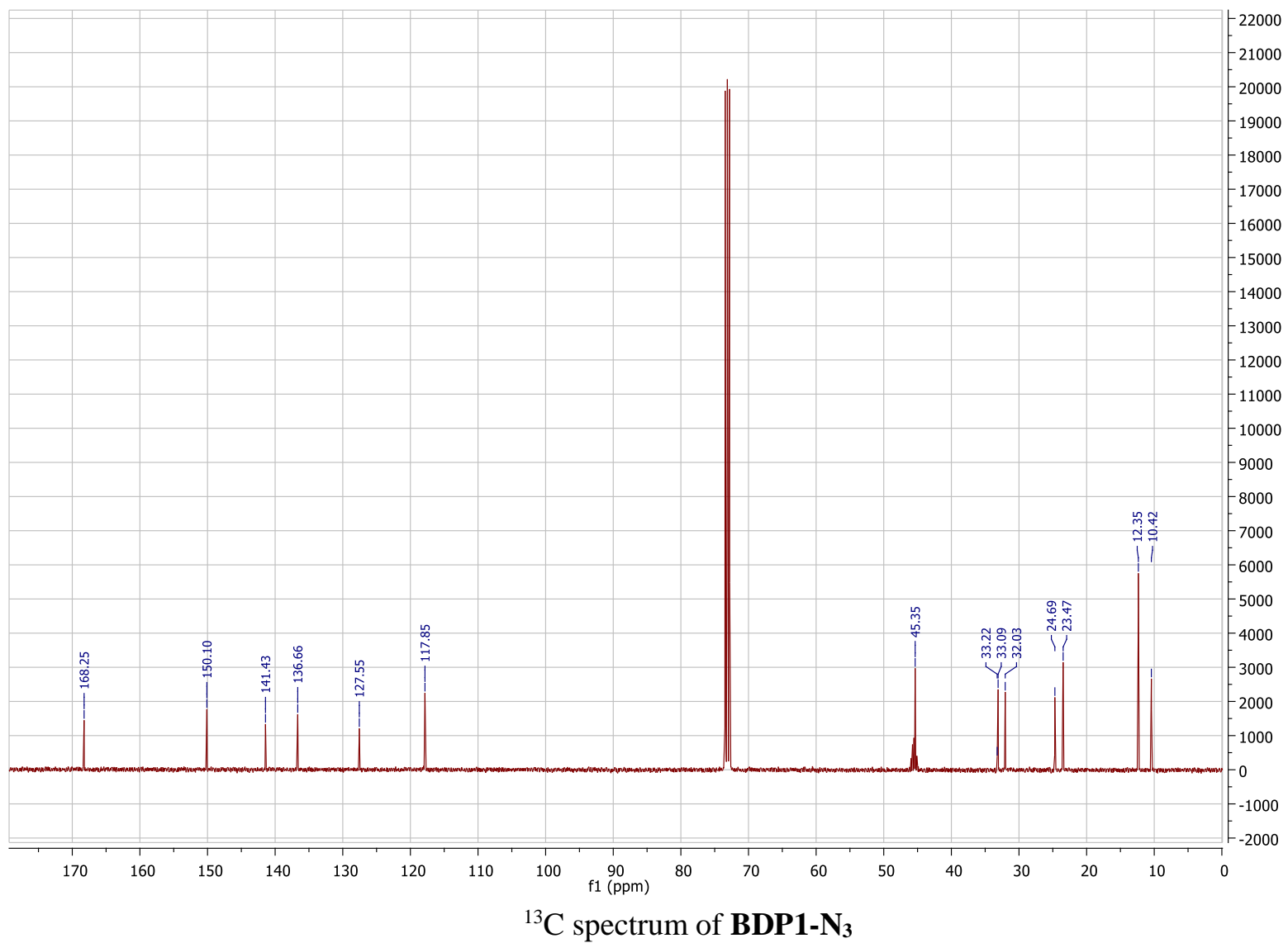




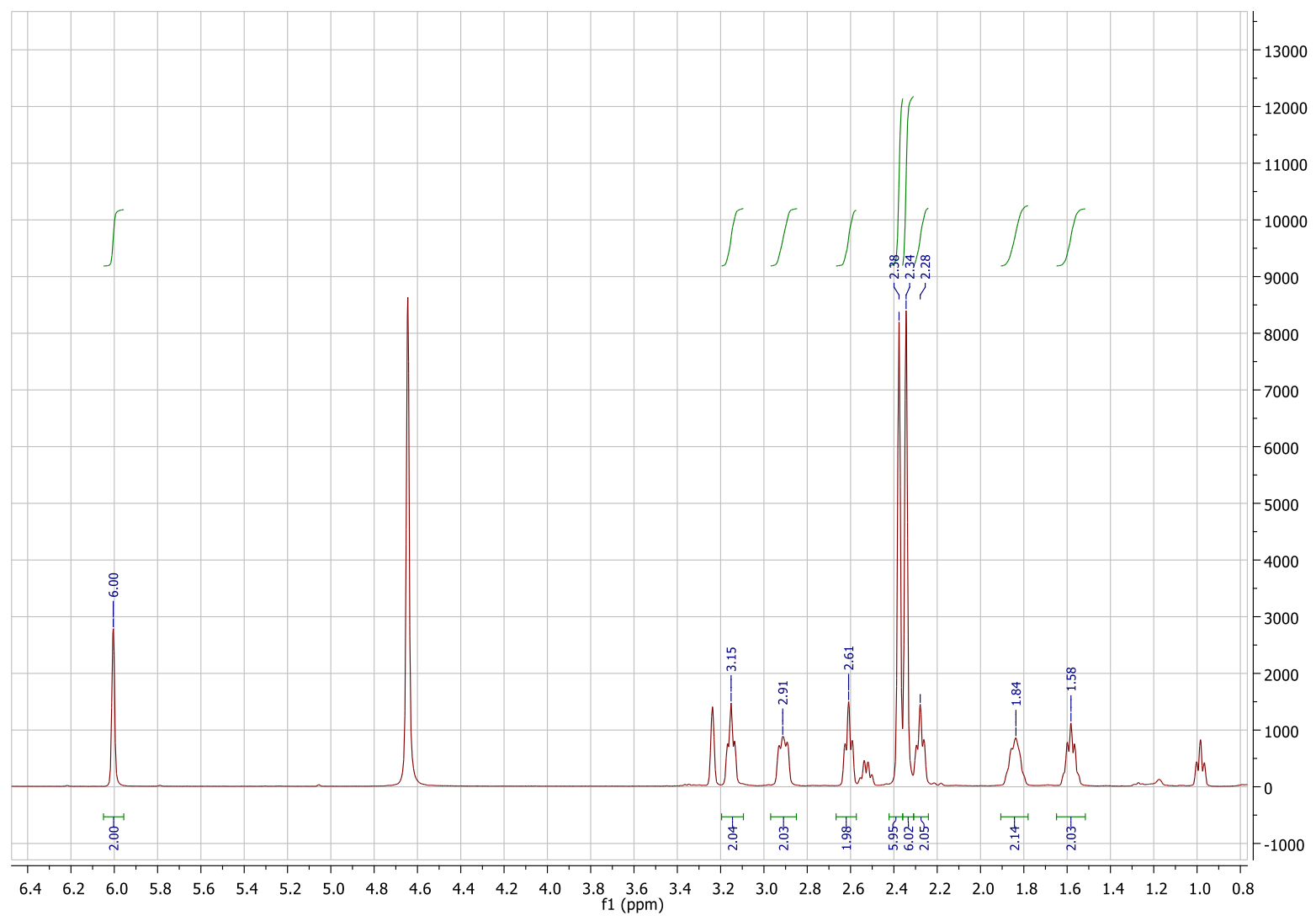

${ }^{1} \mathrm{H}$ spectrum of BDP1

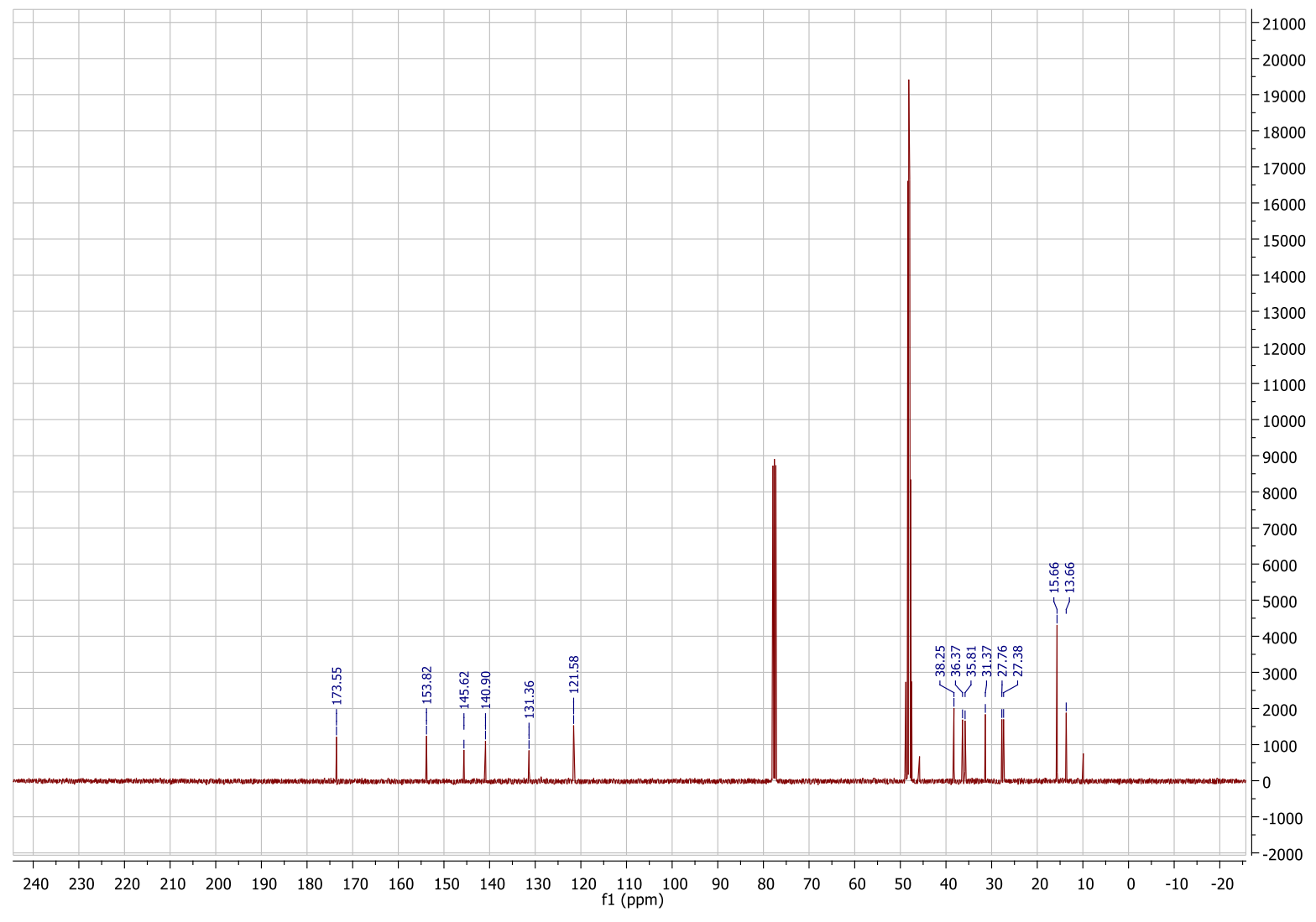

${ }^{13} \mathrm{C}$ spectrum of BDP1 


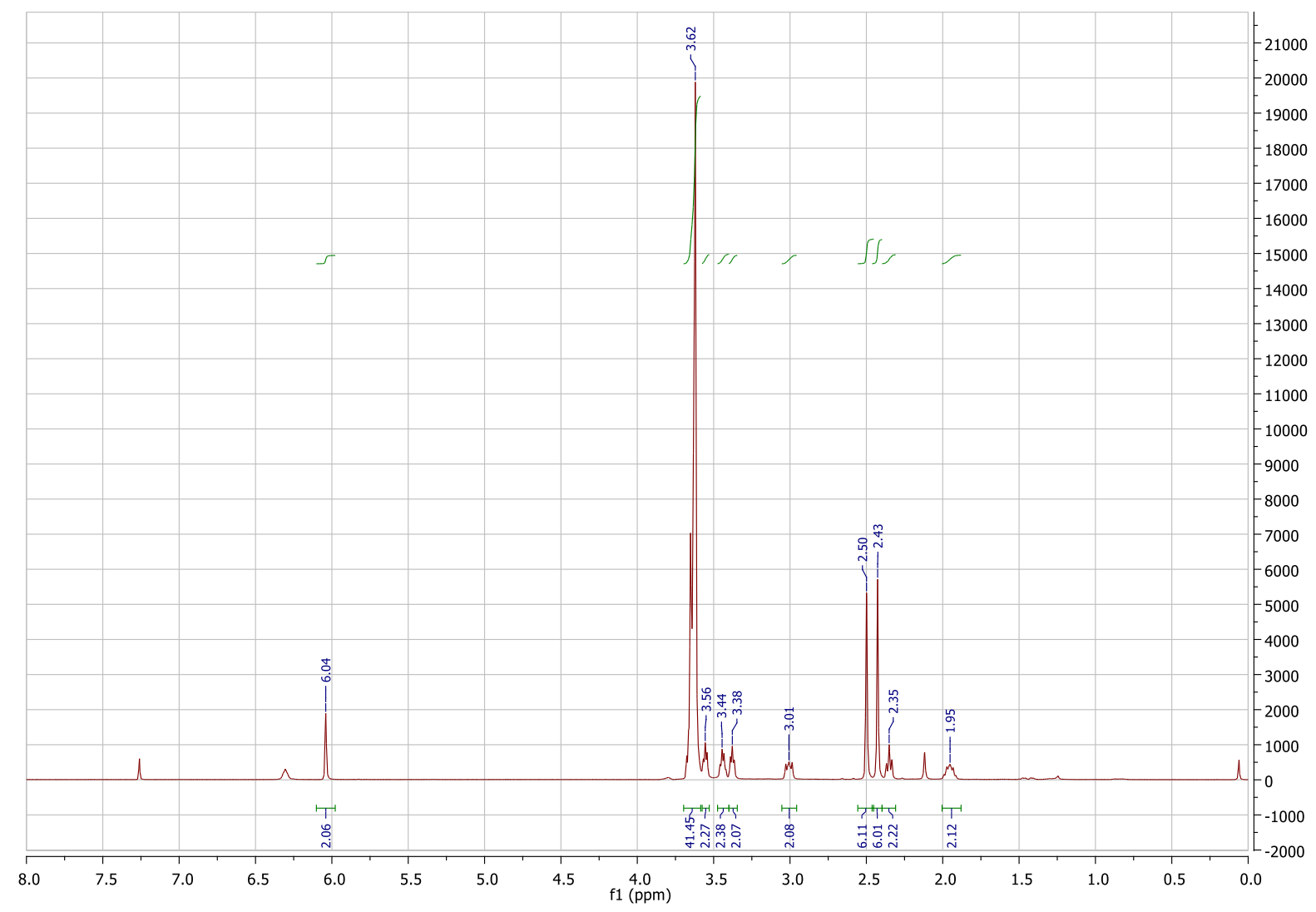

${ }^{1} \mathrm{H}$ spectrum of BDP1-PEG $\mathbf{H}_{12}-\mathbf{N}_{\mathbf{3}}$

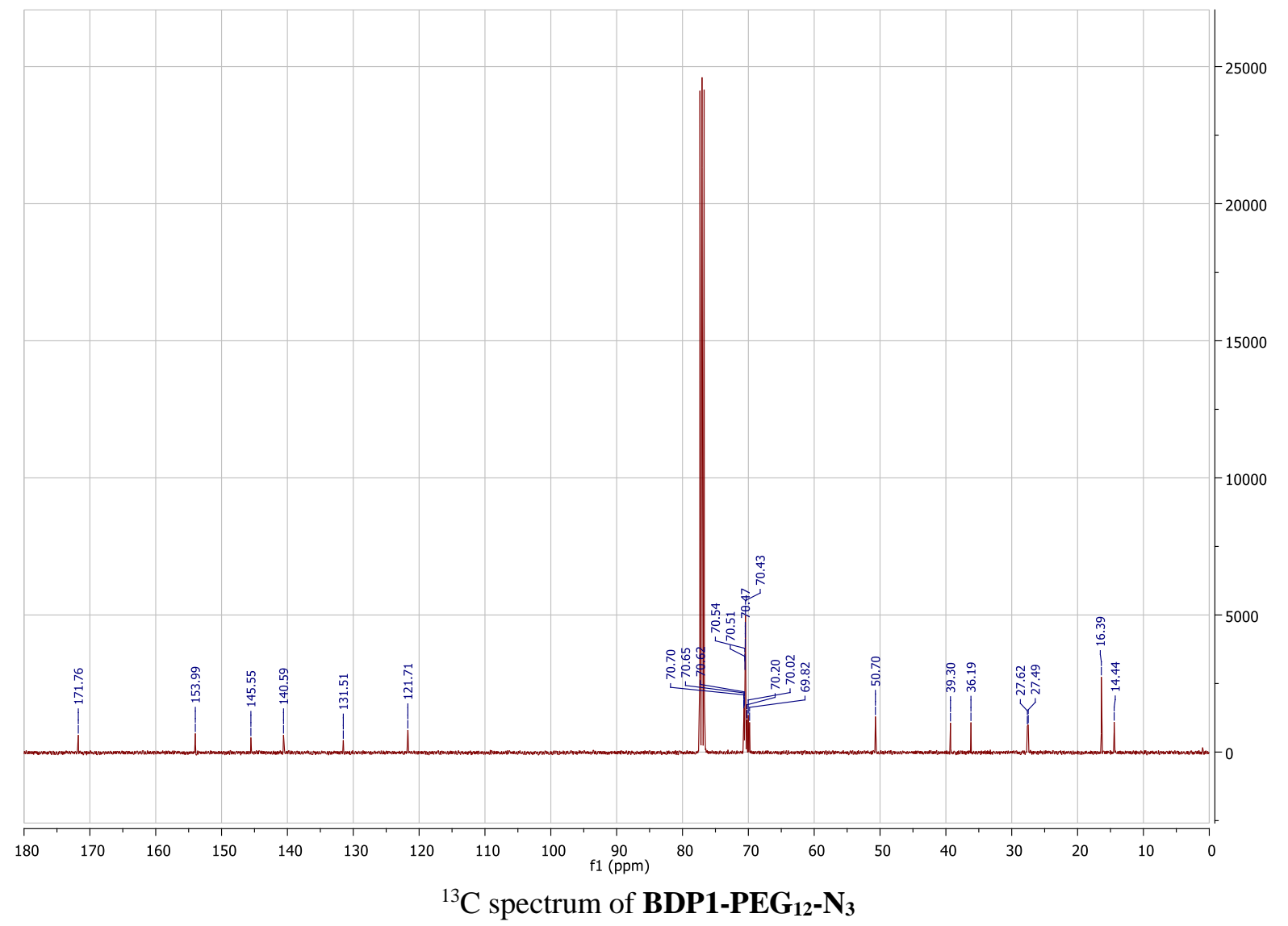




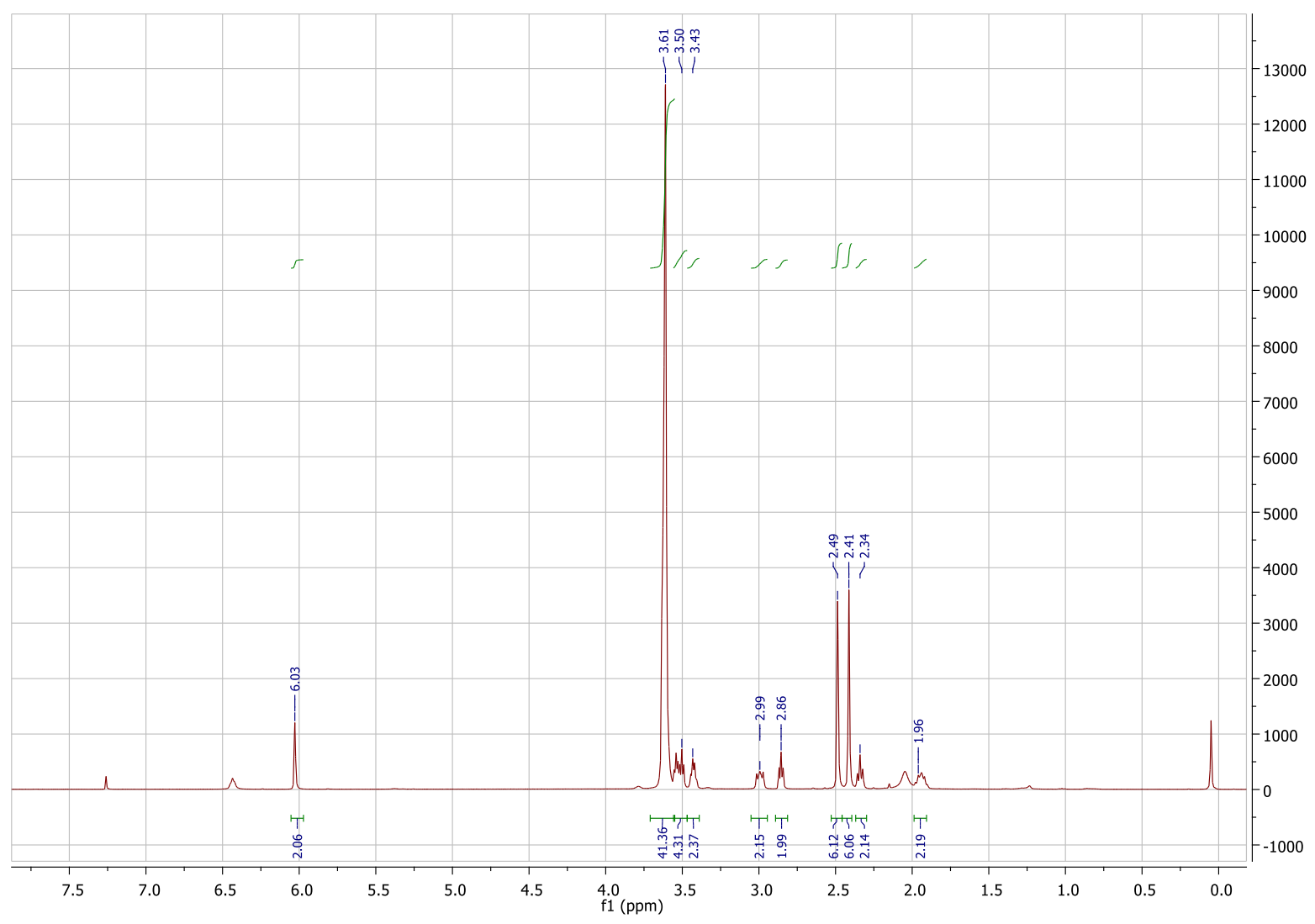

${ }^{1} \mathrm{H}$ spectrum of $\mathbf{B D P 1}-\mathbf{P E G}_{12}$

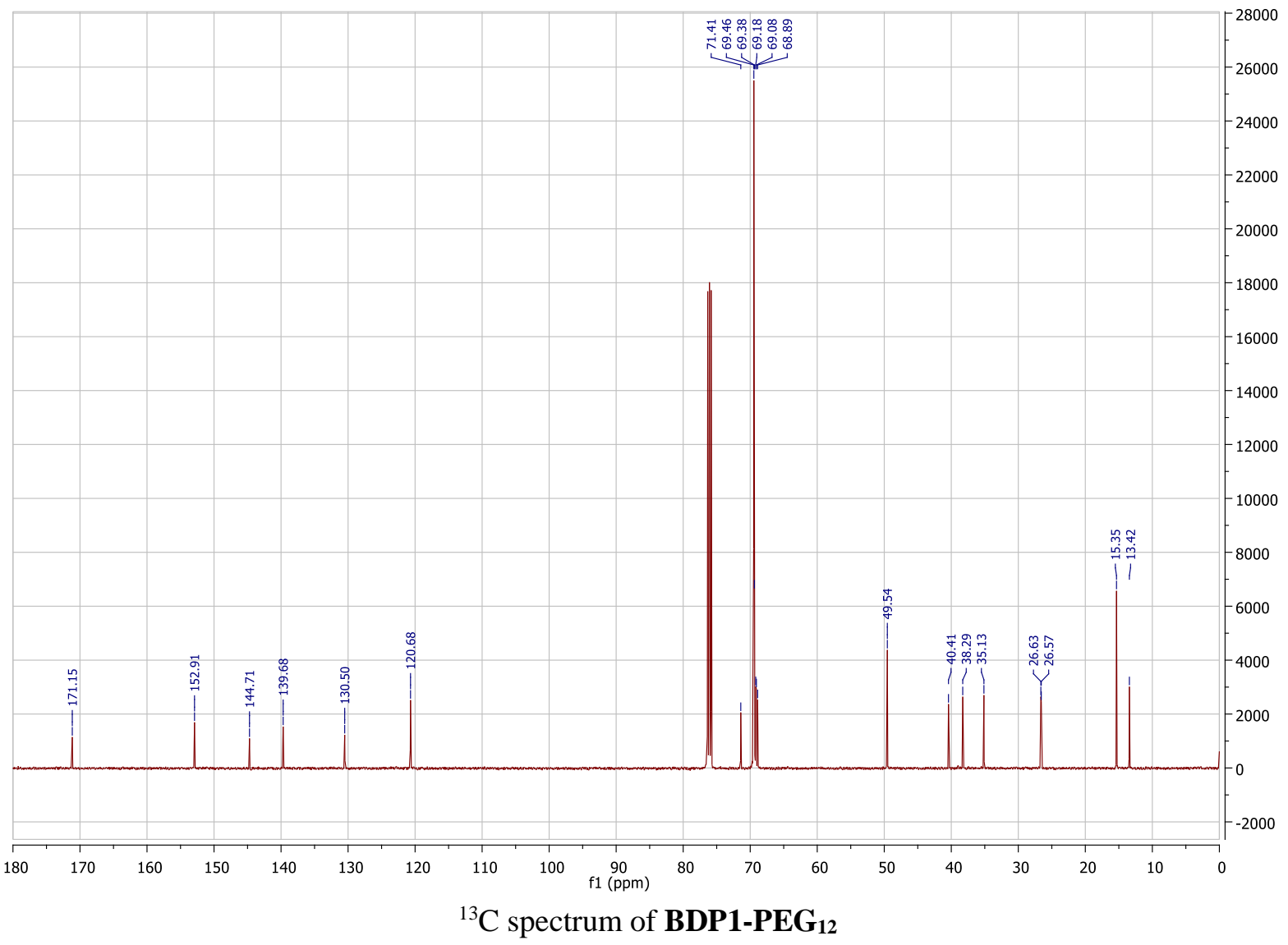




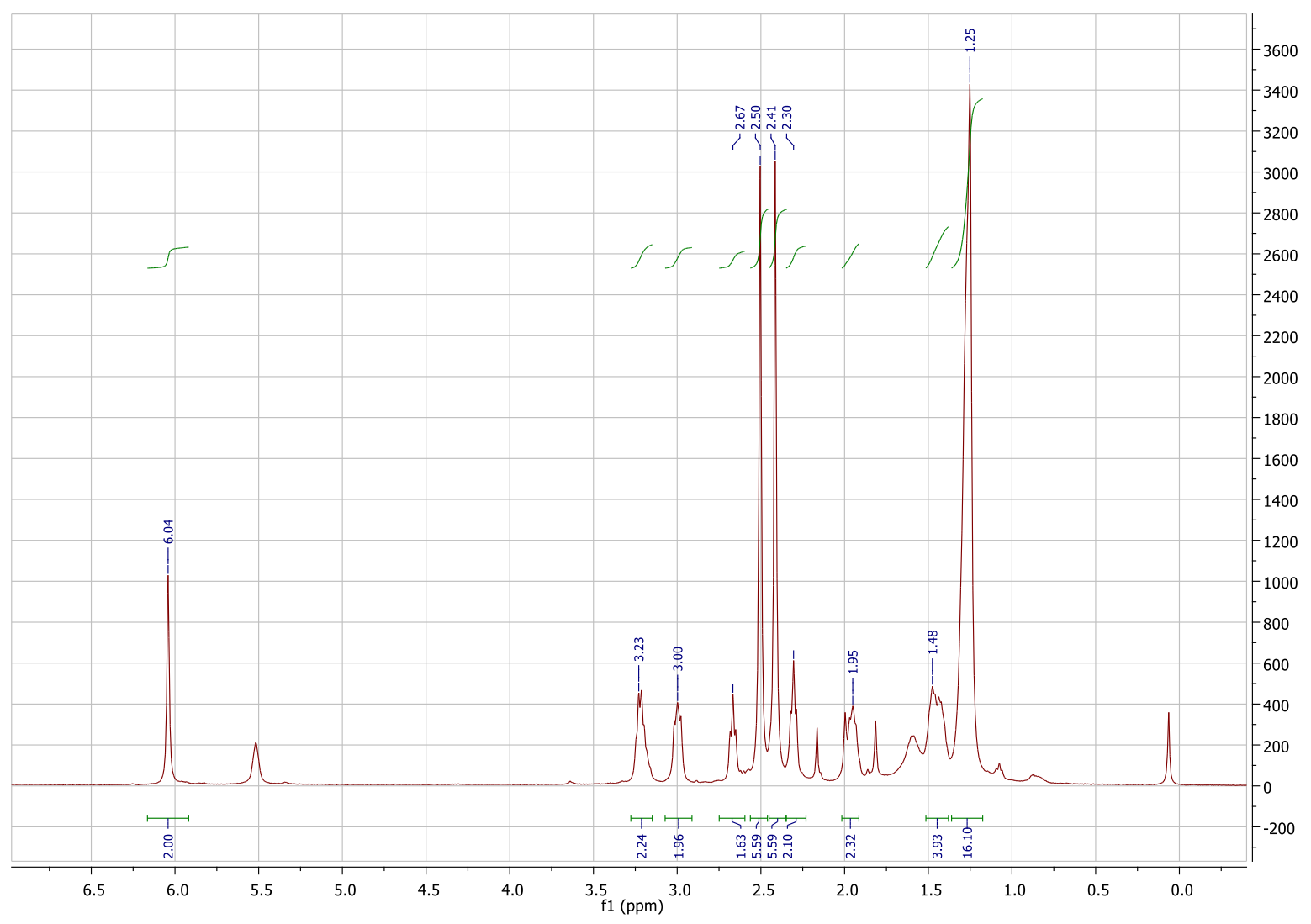

${ }^{1} \mathrm{H}$ spectrum of BDP1-C $\mathbf{C}_{12}$

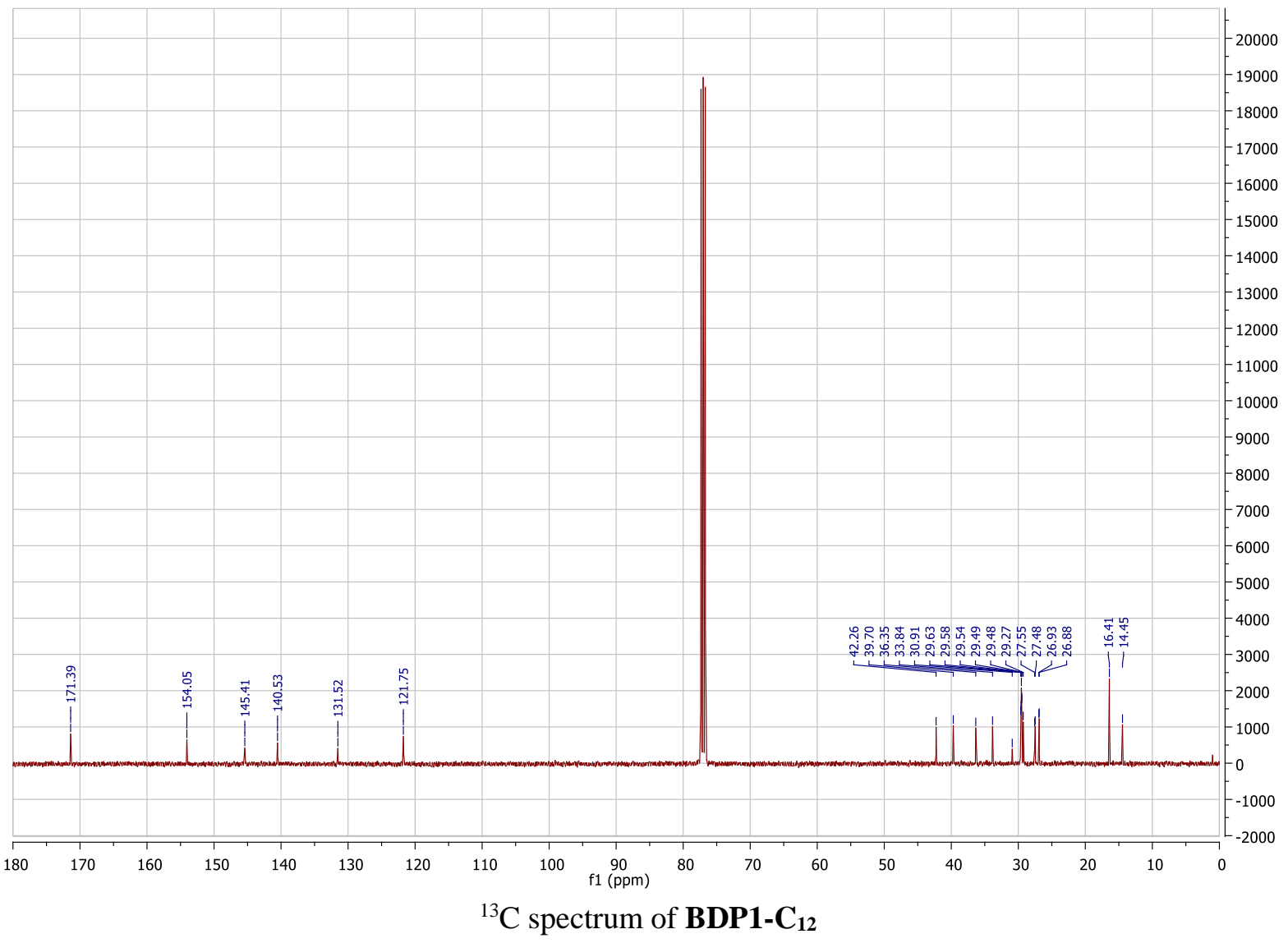




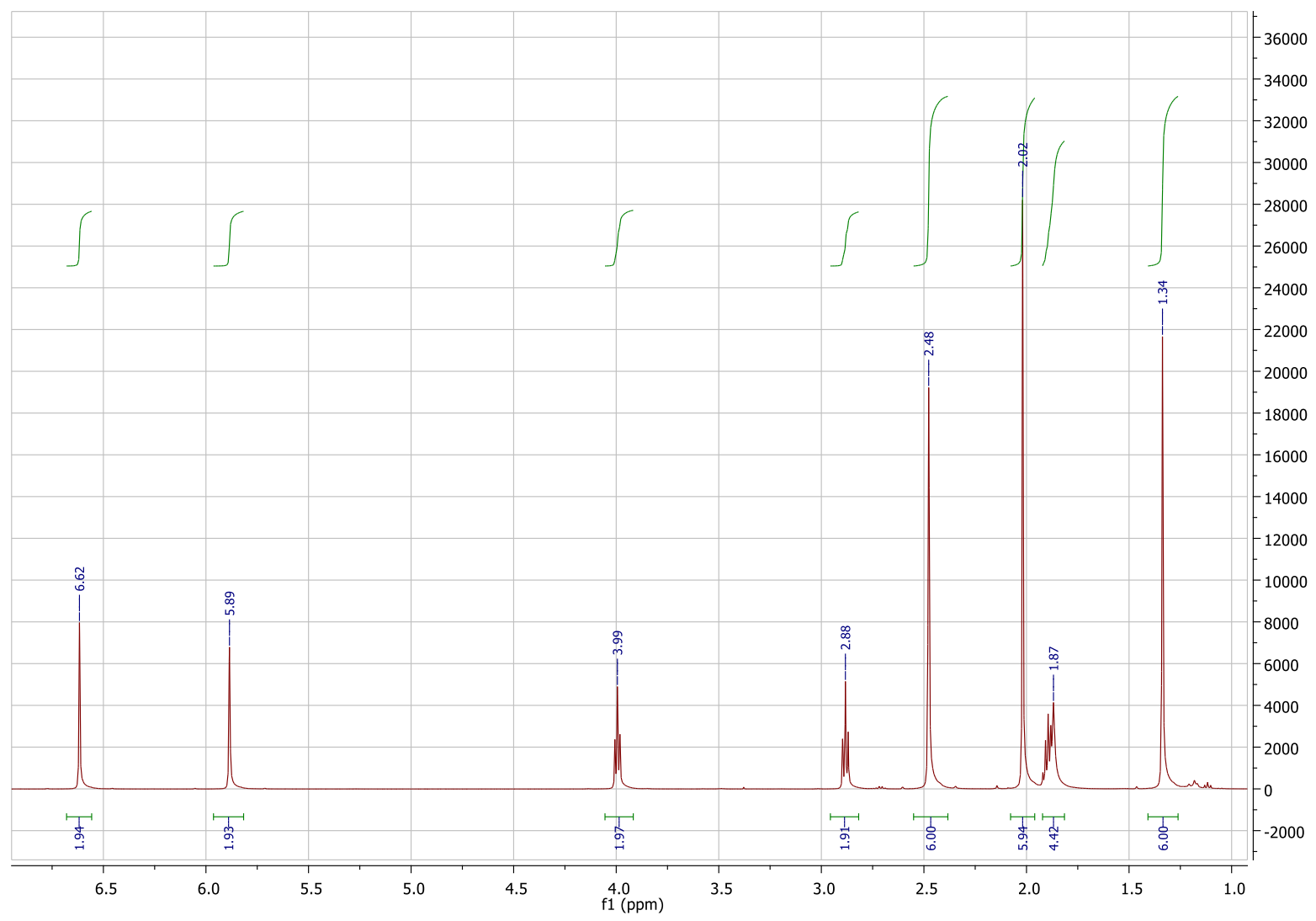

${ }^{1} \mathrm{H}$ spectrum of BDP2

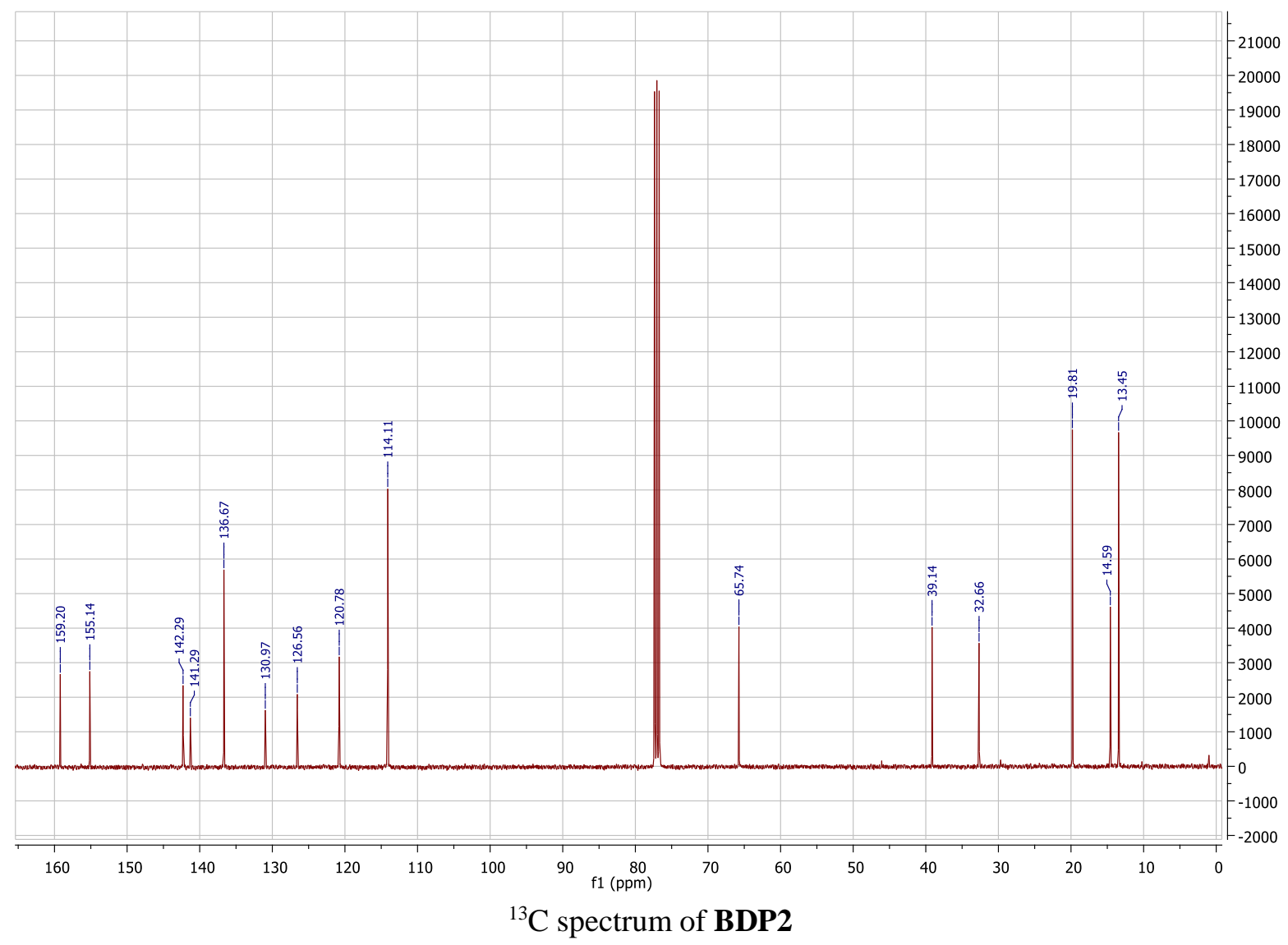




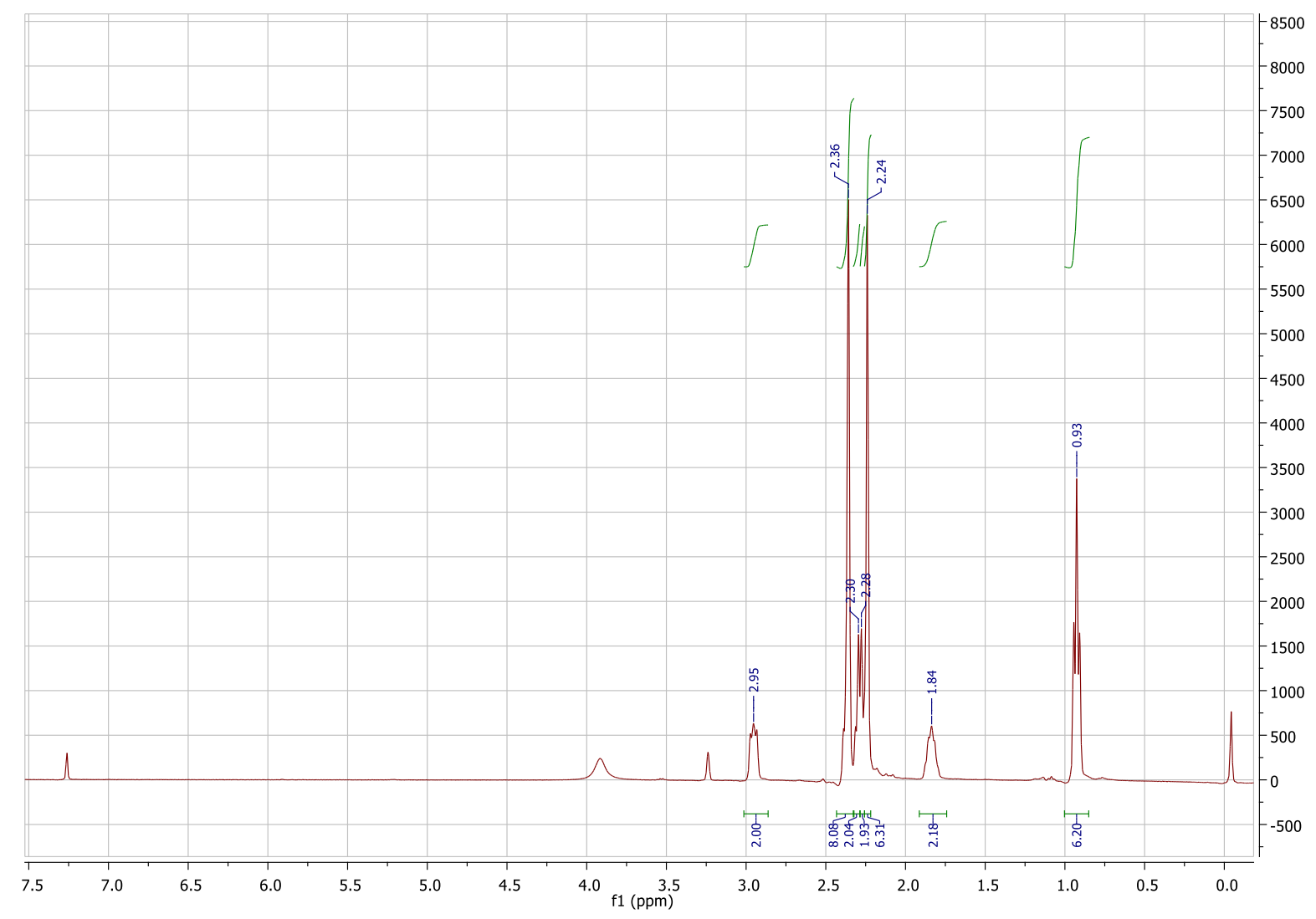

${ }^{1} \mathrm{H}$ spectrum of $\mathbf{3}$

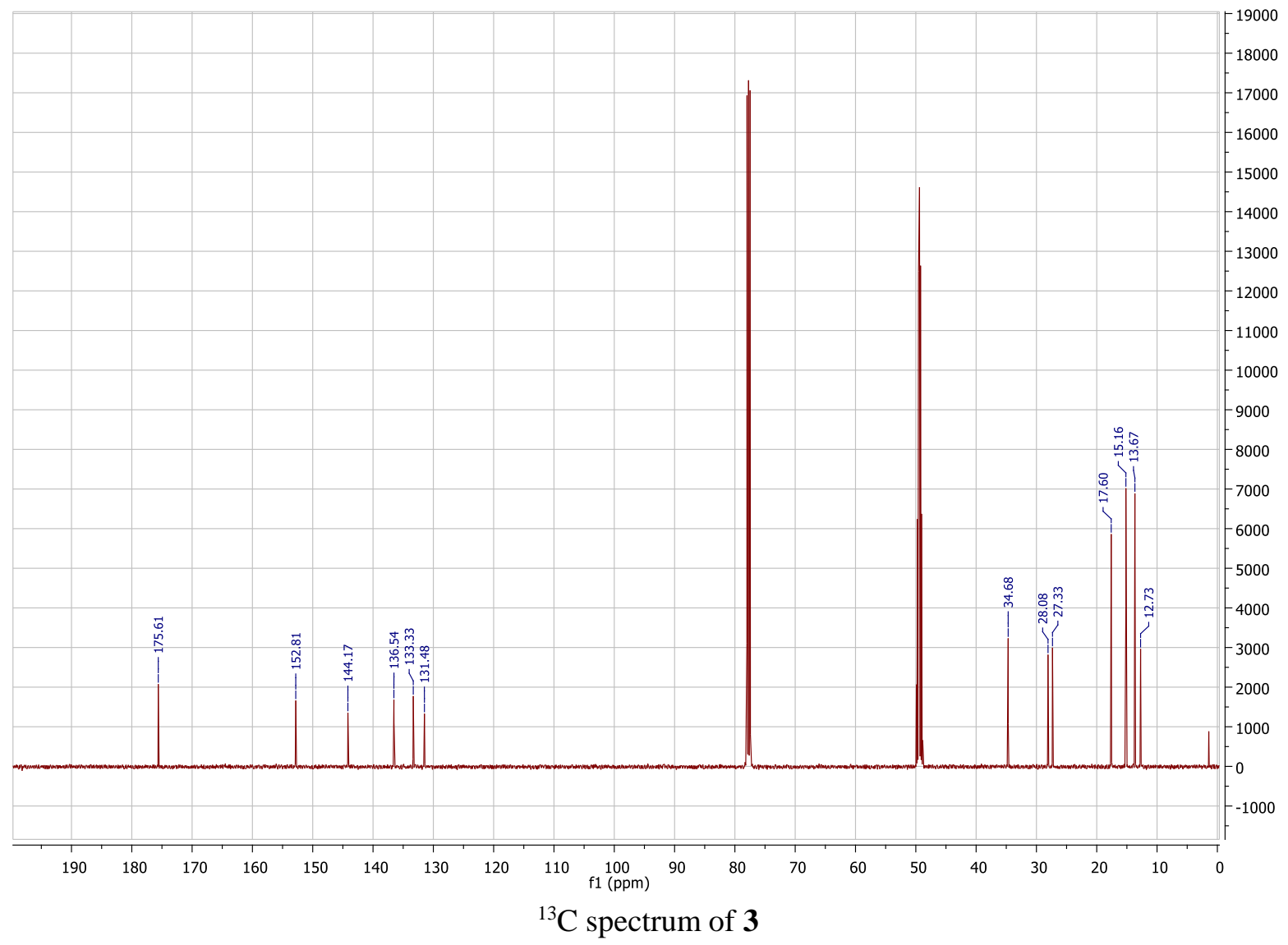




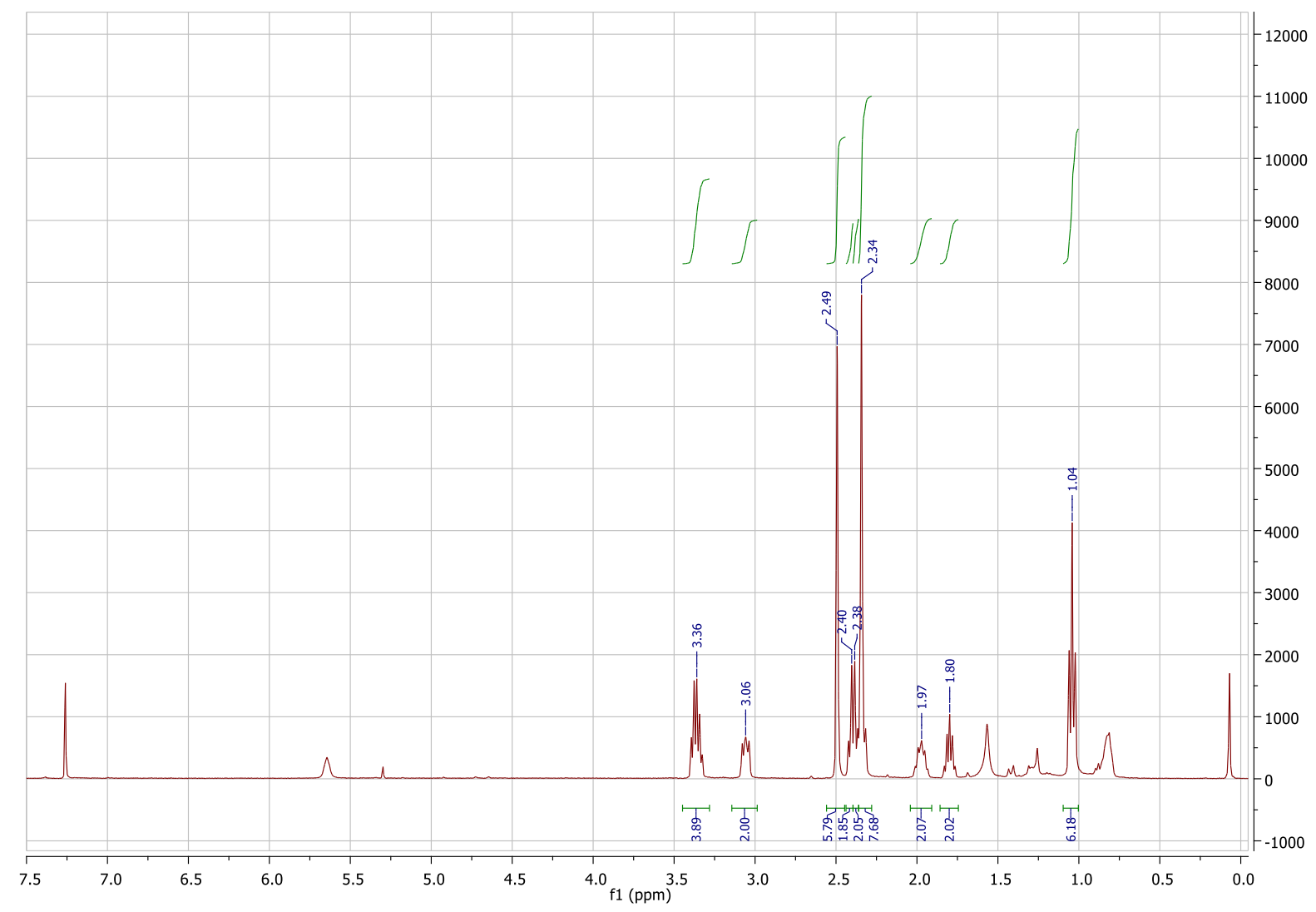

${ }^{1} \mathrm{H}$ spectrum of BDP3-N $\mathbf{N}_{\mathbf{3}}$

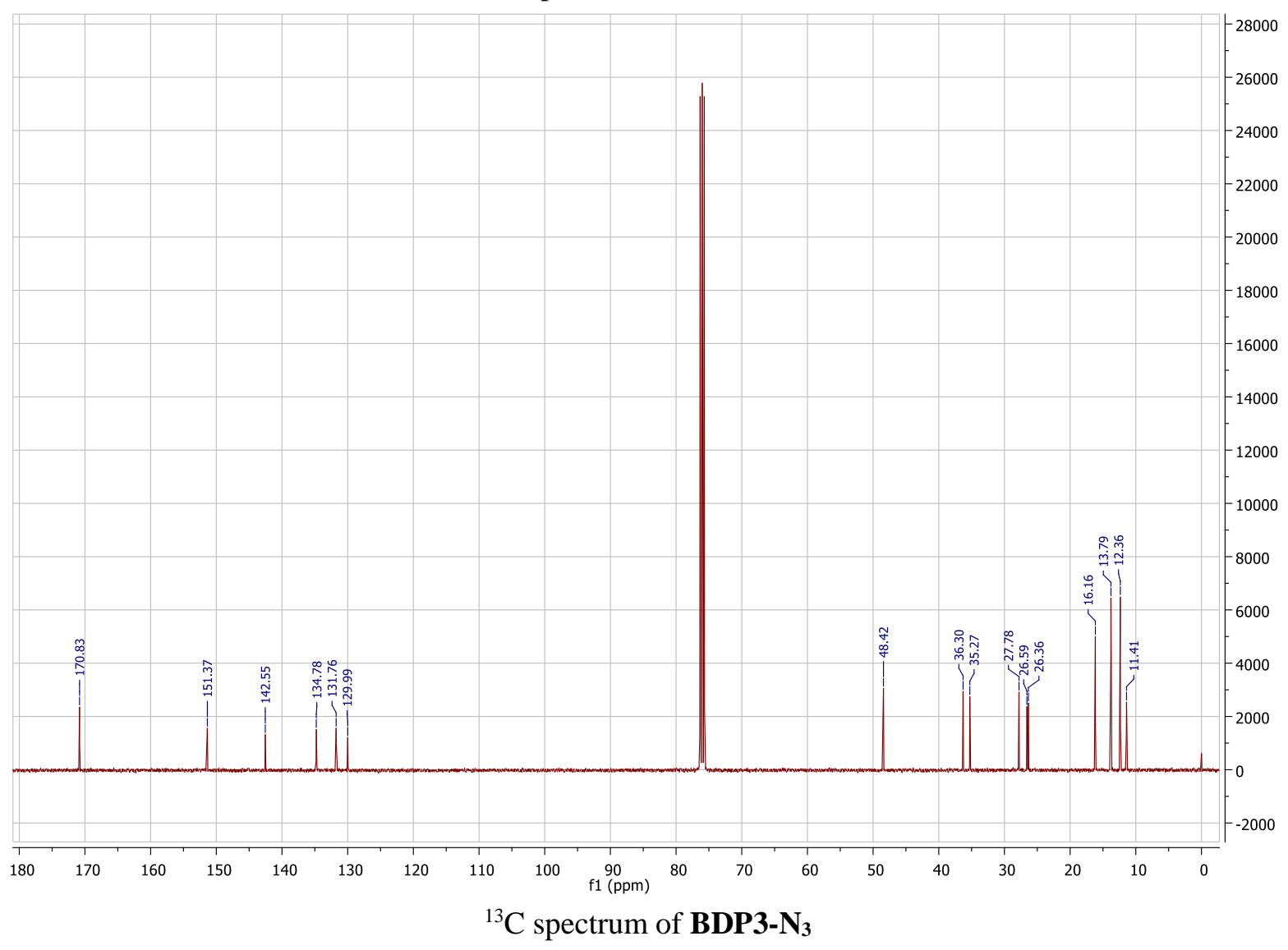




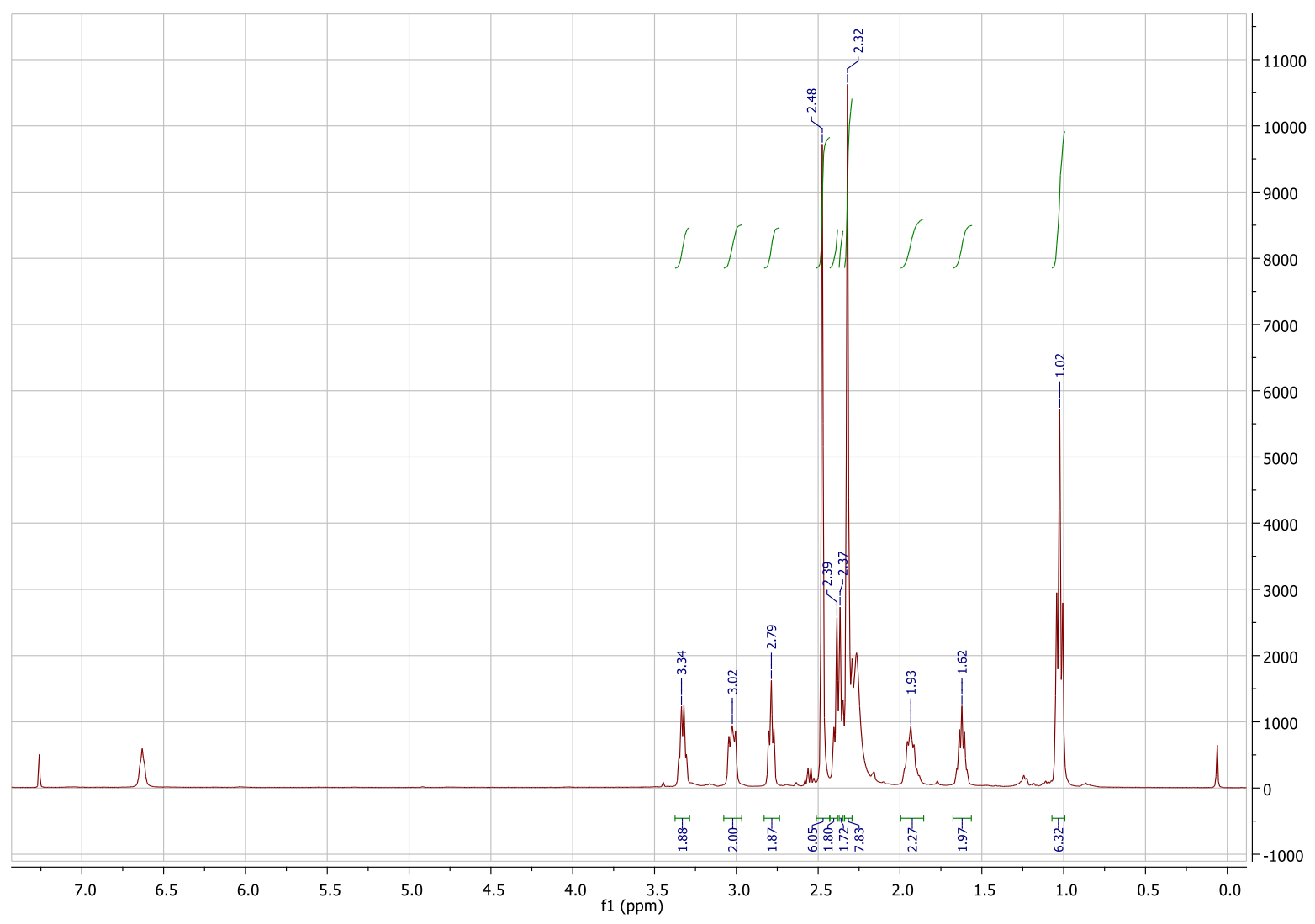

${ }^{1} \mathrm{H}$ spectrum of BDP3

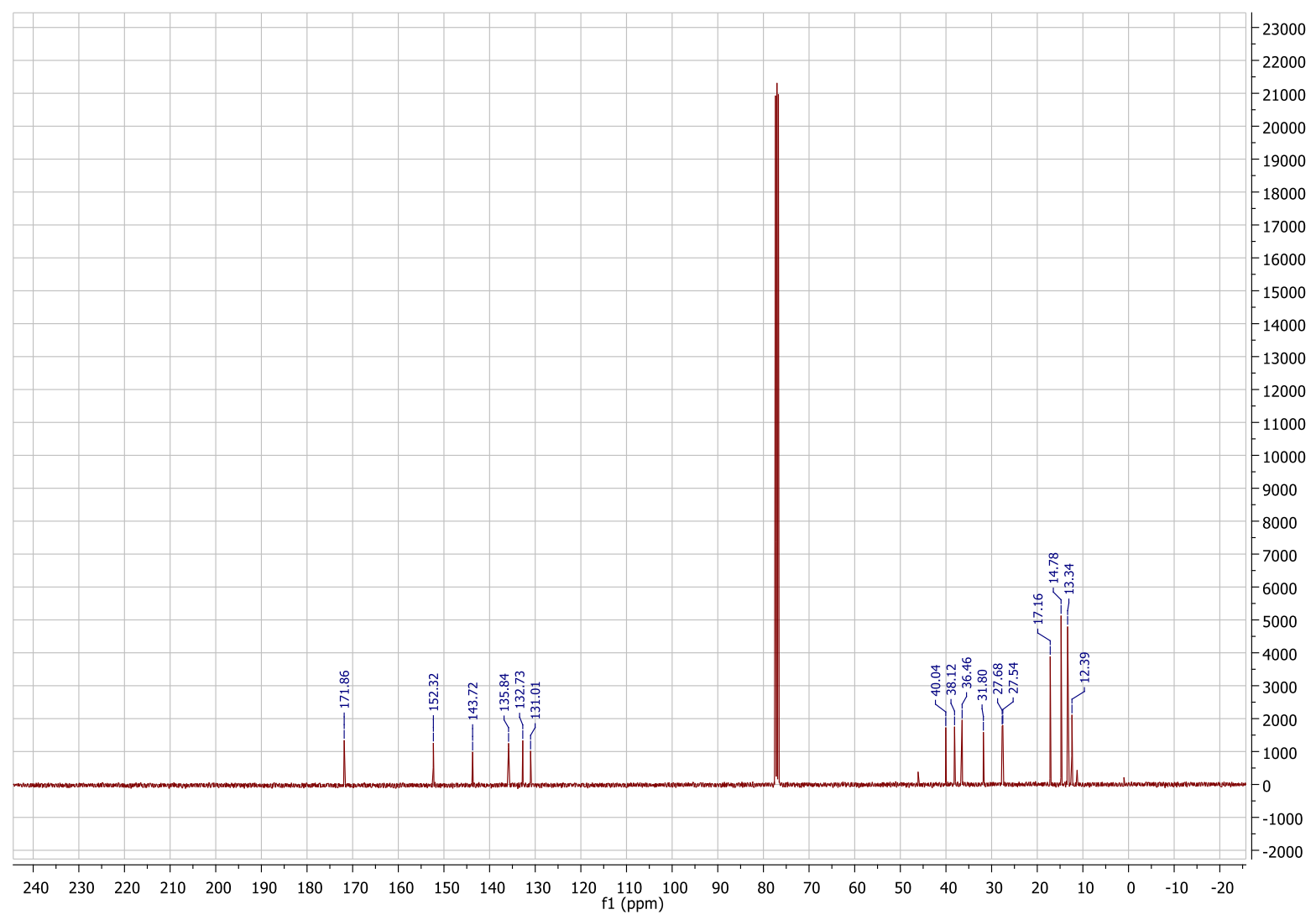

${ }^{13} \mathrm{C}$ spectrum of BDP3 
Mixture of 2 diastereoisomers
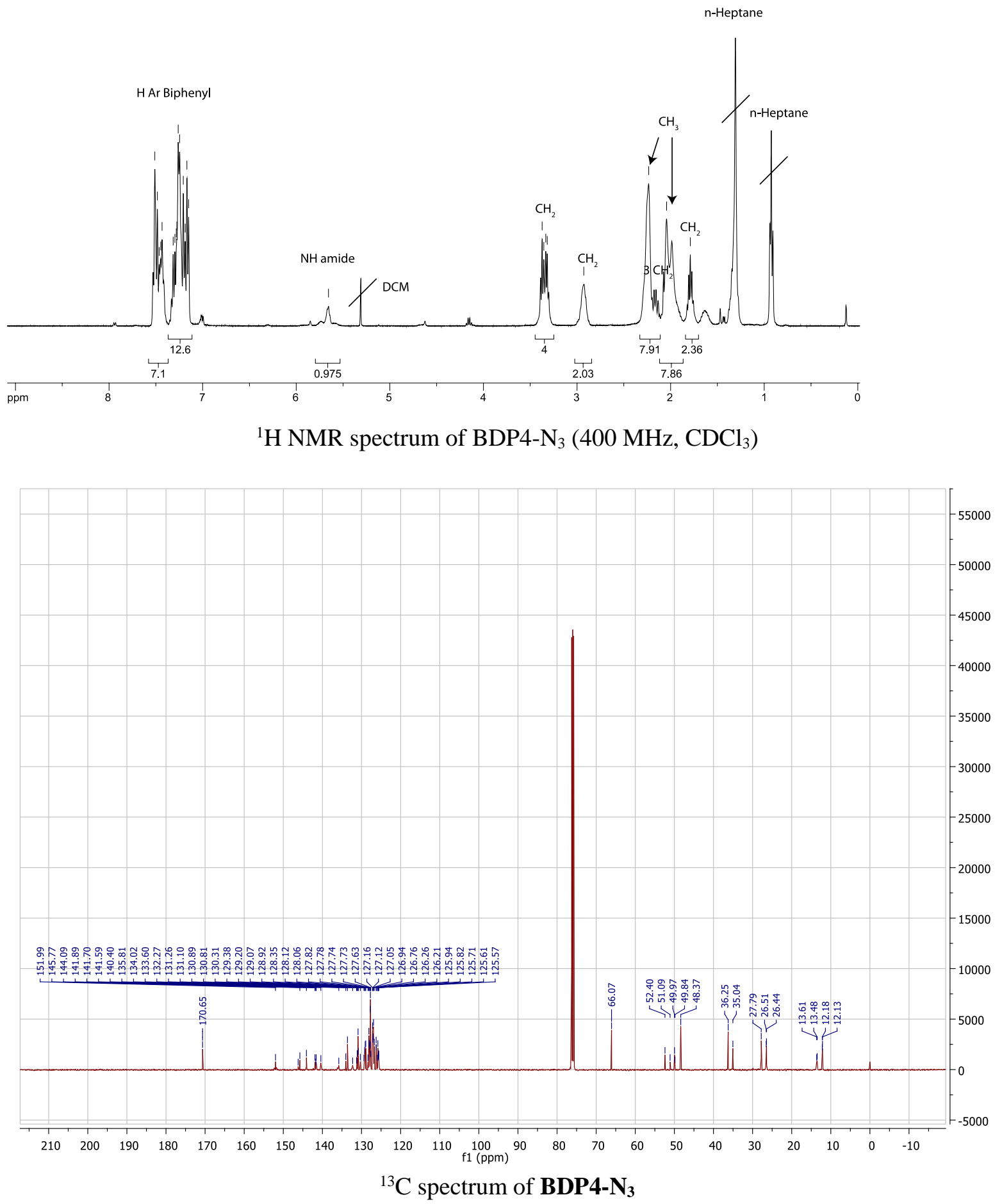


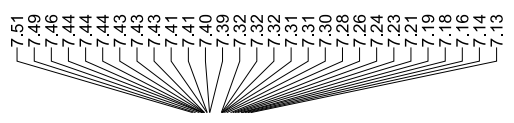

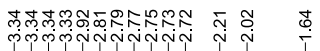

Mixture of 2 diastereoisomers
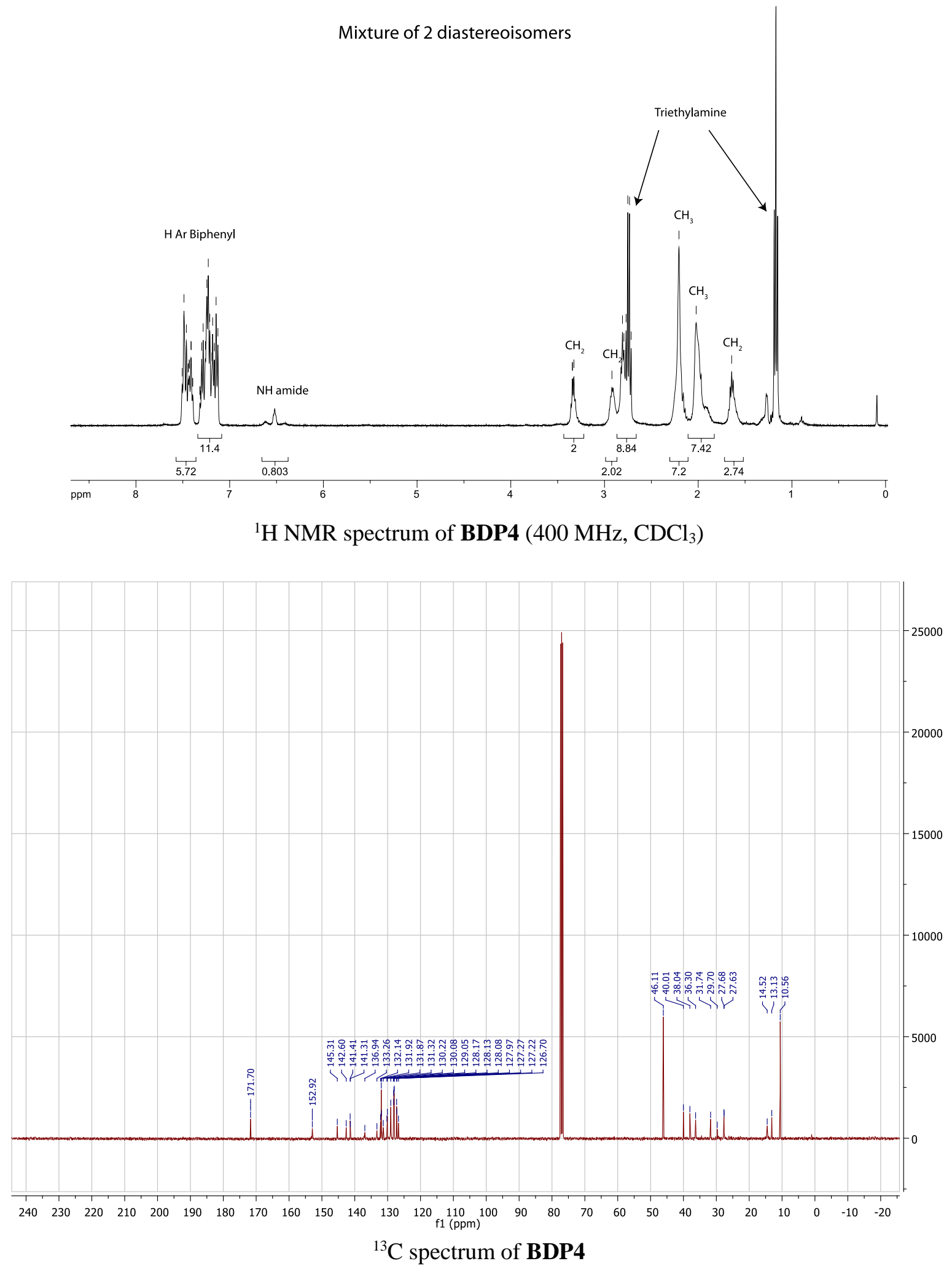


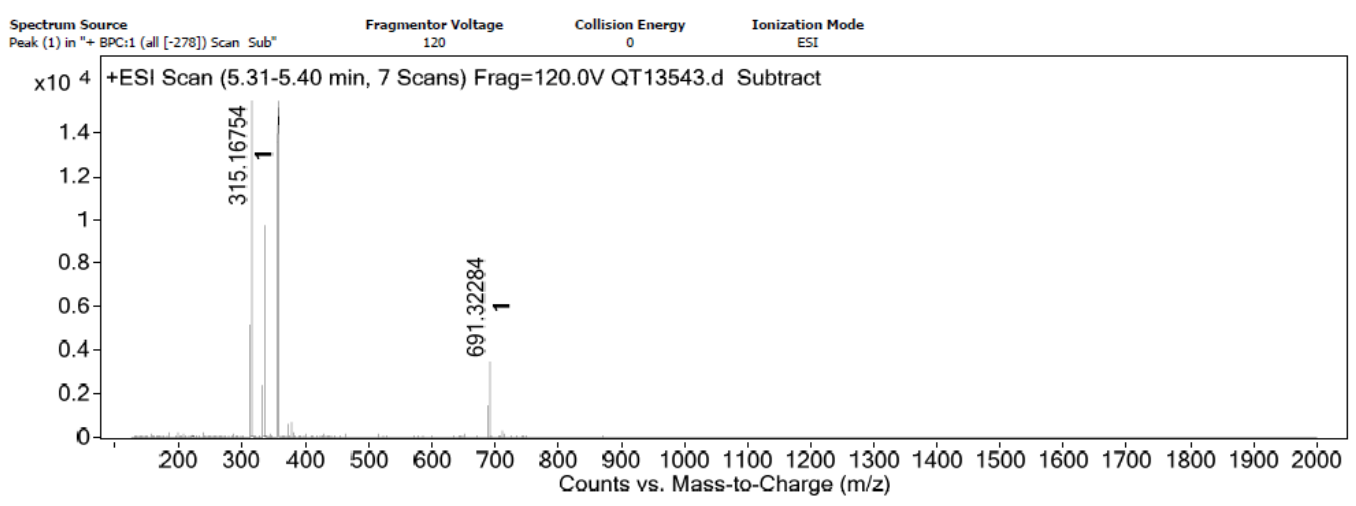

Peak List
\begin{tabular}{|l|l|l|l|l|}
\hline$m / z$ & $z$ & Abund & Formula & Ion \\
\hline 314.17099 & & 5315.5 & & \\
\hline 315.16754 & 1 & 22452.8 & & $(\mathrm{M}+\mathrm{H})+$ \\
\hline 315.2194 & & 1933.4 & & $(\mathrm{M}+\mathrm{H})+$ \\
\hline 316.17132 & 1 & 4069.6 & & \\
\hline 334.17604 & & 2450.1 & & $(\mathrm{M}+\mathrm{H})+$ \\
\hline 335.17384 & 1 & 9765.7 & $\mathrm{C} 17 \mathrm{H} 22 \mathrm{~B} \mathrm{F2} \mathrm{N} 2 \mathrm{O} 2$ & \\
\hline 356.15847 & & 3429.7 & & \\
\hline & & & & \\
357.15611 & 1 & 15465.2 & C17 H21 B F2 N2 Na O2 & $(\mathrm{M}+\mathrm{Na})+$ \\
\hline & & & & \\
\hline 358.15959 & 1 & 2464.3 & C17 H21 B F2 N2 Na O2 & $(\mathrm{M}+\mathrm{Na})+$ \\
\hline 691.32284 & 1 & 3498.1 & & \\
\hline
\end{tabular}

\section{HRMS spectra of $\mathbf{1}$}

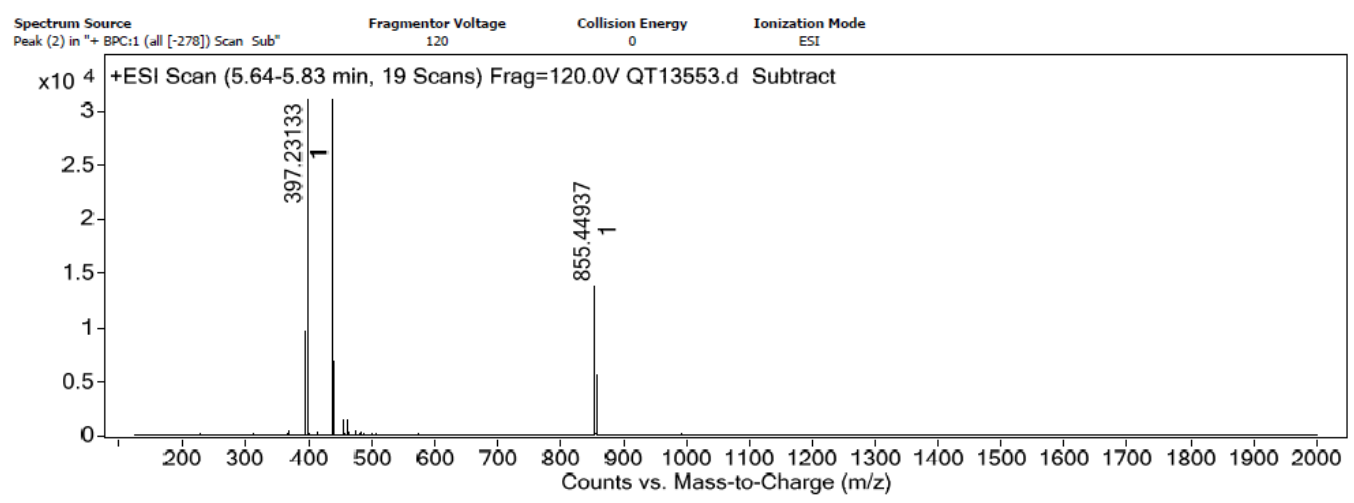

Peak List
\begin{tabular}{|l|c|l|l|l|}
\hline$m / z$ & $z$ & Abund & Formula & Ion \\
\hline 396.23437 & & 9763.2 & & \\
\hline 397.23133 & 1 & 45872 & & $(\mathrm{M}+\mathrm{H})+$ \\
\hline 397.29162 & & 3634 & & \\
\hline 398.23418 & 1 & 9905.3 & & $(\mathrm{M}+\mathrm{H})+$ \\
\hline 438.22232 & & 6777.5 & & \\
\hline 439.21953 & 1 & 31578.9 & $\mathrm{C} 20 \mathrm{H} 27 \mathrm{~B} \mathrm{F2} \mathrm{N6} \mathrm{Na} 0$ & $(\mathrm{M}+\mathrm{Na})+$ \\
\hline 440.22212 & 1 & 6888.5 & $\mathrm{C} 20 \mathrm{H} 27 \mathrm{~B} \mathrm{F2} \mathrm{N} 6 \mathrm{Na}$ O & $(\mathrm{M}+\mathrm{Na})+$ \\
\hline 854.45191 & & 5608.4 & & \\
\hline 855.44937 & 1 & 13879 & $\mathrm{C} 40 \mathrm{H} 54 \mathrm{~B} 2 \mathrm{~F} 4 \mathrm{~N} 12 \mathrm{Na} 02$ & $(2 \mathrm{M}+\mathrm{Na})+$ \\
\hline 856.45154 & 1 & 5600.8 & $\mathrm{C} 40 \mathrm{H} 54 \mathrm{~B} 2 \mathrm{~F} 4 \mathrm{~N} 12 \mathrm{Na} 02$ & $(2 \mathrm{M}+\mathrm{Na})+$ \\
\hline
\end{tabular}

HRMS spectra of BDP1-N 3 


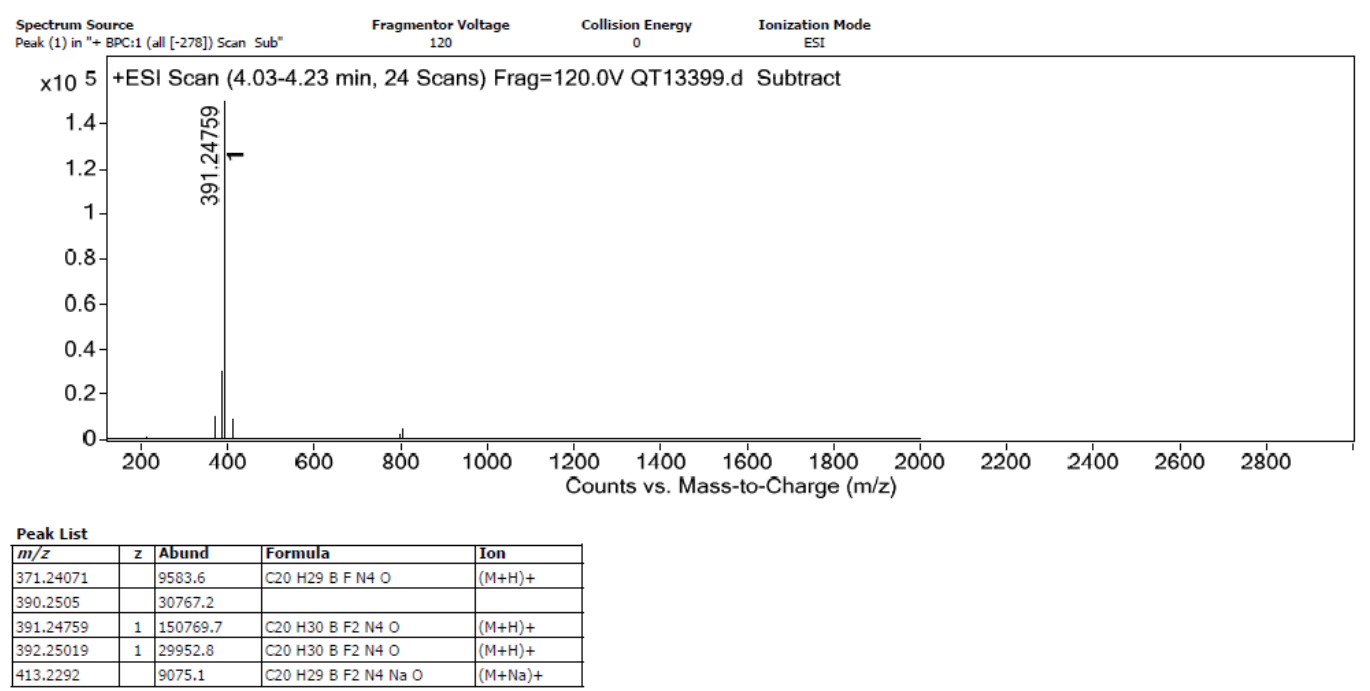

HRMS spectra of BDP1

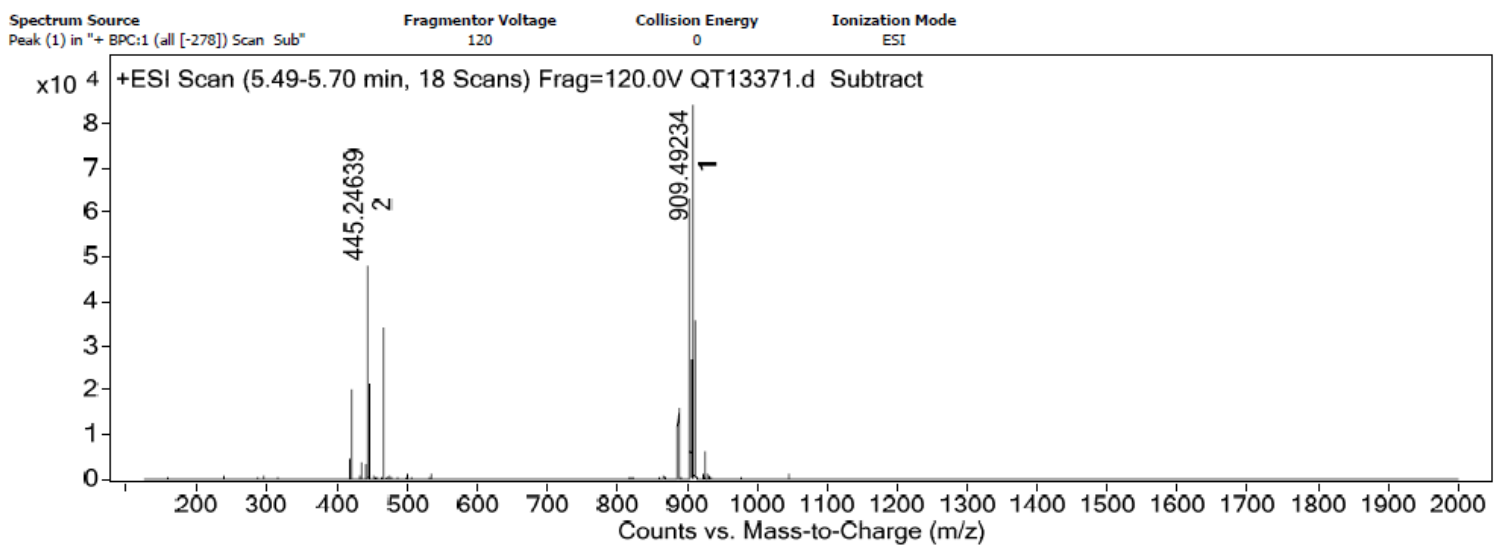

Peak List
\begin{tabular}{|l|l|l|l|l|l|}
\hline$m / z$ & $z$ & Abund & Formula & Ion \\
\hline 420.2524 & 2 & 20809.3 & & \\
\hline 445.24639 & 2 & 48169 & & $(M+2 \mathrm{H})+2$ \\
\hline 445.74769 & 2 & 21275.8 & & $(\mathrm{M}+2 \mathrm{H})+2$ \\
\hline & & & & \\
466.24078 & 2 & 34107.6 & C41 H69 B F2 N6 Na2 O12 & $(\mathrm{M}+2 \mathrm{Na})+2$ \\
\hline 887.50965 & 1 & 16089.9 & C41 H70 B F2 N6 O12 & $(\mathrm{M}+\mathrm{H})+$ \\
\hline 904.53667 & 1 & 63556.5 & C41 H73 B F2 N7 O12 & $(\mathrm{M}+\mathrm{NH} 4)+$ \\
\hline 905.53909 & 1 & 27103.1 & C41 H73 B F2 N7 O12 & $(\mathrm{M}+\mathrm{NH} 4)+$ \\
\hline 908.49501 & & 16633 & & \\
\hline 909.49234 & 1 & 86190.2 & C41 H69 B F2 N6 Na 012 & $(\mathrm{M}+\mathrm{Na})+$ \\
\hline 910.49485 & 1 & 36291 & C41 H69 B F2 N6 Na O12 & $(\mathrm{M}+\mathrm{Na})+$ \\
\hline
\end{tabular}

HRMS spectra of BDP1-PEG $\mathbf{H}_{12}-\mathbf{N}_{\mathbf{3}}$ 


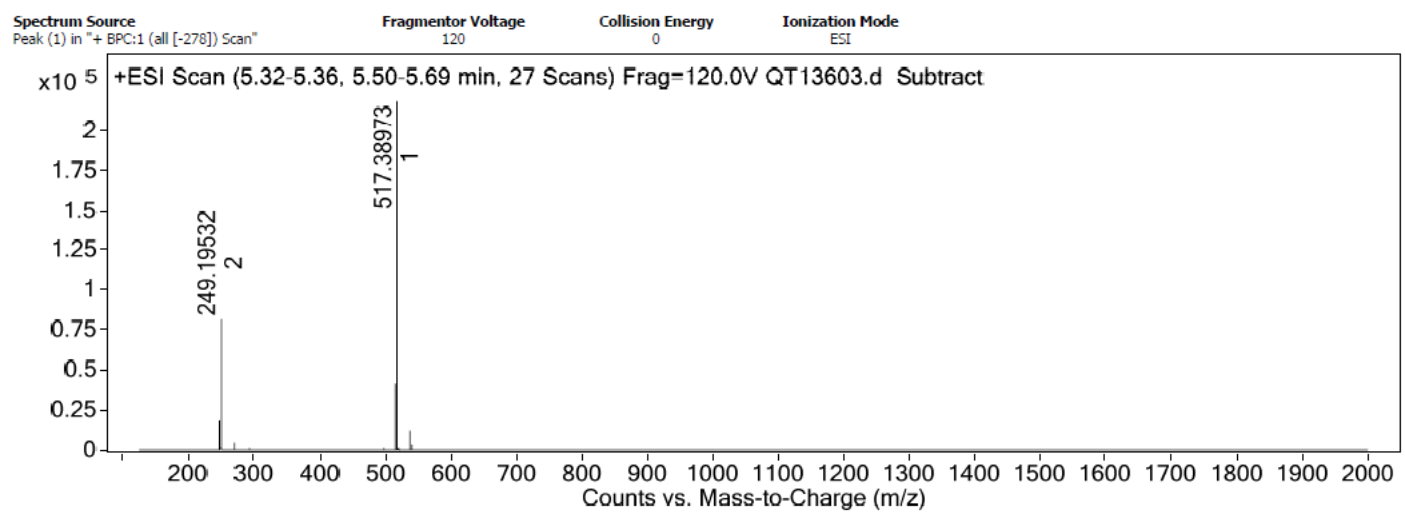

Peak List
\begin{tabular}{|l|c|l|l|l|l|}
\hline$m / z$ & $\mathrm{z}$ & Abund & Formula & Ion \\
\hline 248.69682 & & 18217.2 & & \\
\hline 249.19532 & 2 & 83666.3 & & $(\mathrm{M}+2 \mathrm{H})+2$ \\
\hline 249.69656 & 2 & 25591.5 & & $(\mathrm{M}+2 \mathrm{H})+2$ \\
\hline 516.39222 & & 42593.4 & & \\
\hline 517.38973 & 1 & 218730 & $\mathrm{C} 29 \mathrm{H} 48$ B F2 N4 O & $(\mathrm{M}+\mathrm{H})+$ \\
\hline 518.39195 & 1 & 61892.9 & $\mathrm{C} 29 \mathrm{H} 48$ B F2 N4 O & $(\mathrm{M}+\mathrm{H})+$ \\
\hline 539.37077 & & 11704 & $\mathrm{C} 29 \mathrm{H} 47$ B F2 N4 Na O & $(\mathrm{M}+\mathrm{Na})+$ \\
\hline
\end{tabular}

HRMS spectra of BDP1-PEG $\mathbf{H}_{12}$

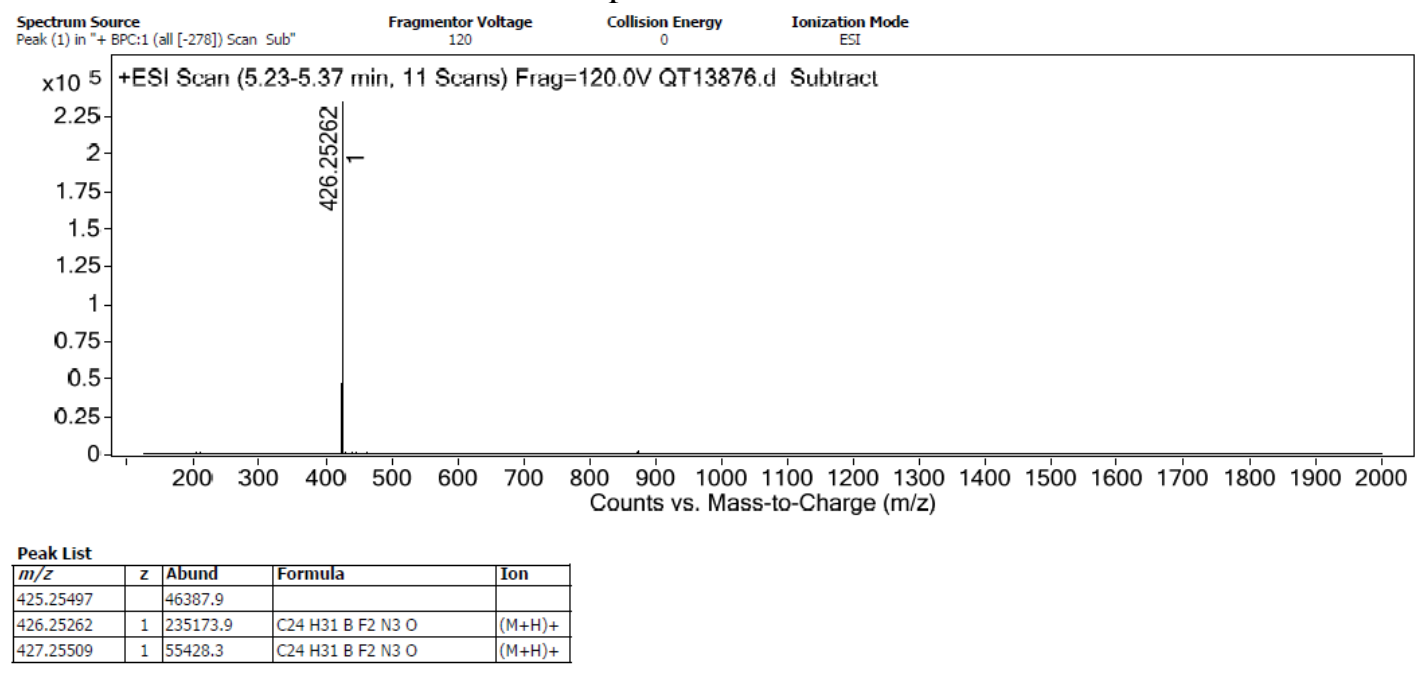

HRMS spectra of BDP2 


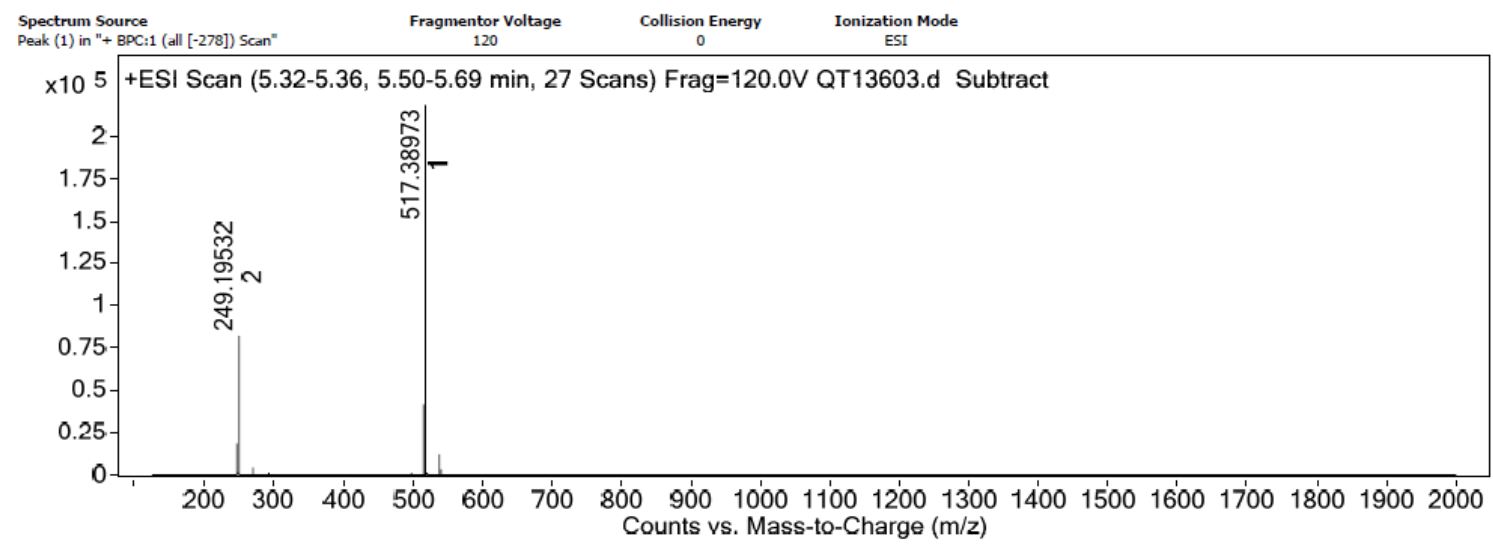

Peak List
\begin{tabular}{|l|c|l|l|l|l|}
\hline$m / z$ & $z$ & Abund & Formula & Ion \\
\hline 248.69682 & & 18217.2 & & \\
\hline 249.19532 & 2 & 83666.3 & & $(\mathrm{M}+2 \mathrm{H})+2$ \\
\hline 249.69656 & 2 & 25591.5 & & $(\mathrm{M}+2 \mathrm{H})+2$ \\
\hline 516.39222 & & 42593.4 & & \\
\hline 517.38973 & 1 & 218730 & $\mathrm{C} 29 \mathrm{H} 48$ B F2 N4 O & $(\mathrm{M}+\mathrm{H})+$ \\
\hline 518.39195 & 1 & 61892.9 & $\mathrm{C} 29 \mathrm{H} 48$ B F2 N4 O & $(\mathrm{M}+\mathrm{H})+$ \\
\hline 539.37077 & & 11704 & $\mathrm{C} 29 \mathrm{H} 47$ B F2 N4 Na O & $(\mathrm{M}+\mathrm{Na})+$ \\
\hline
\end{tabular}

HRMS spectra of BDP1- $\mathbf{C}_{\mathbf{1 2}}$

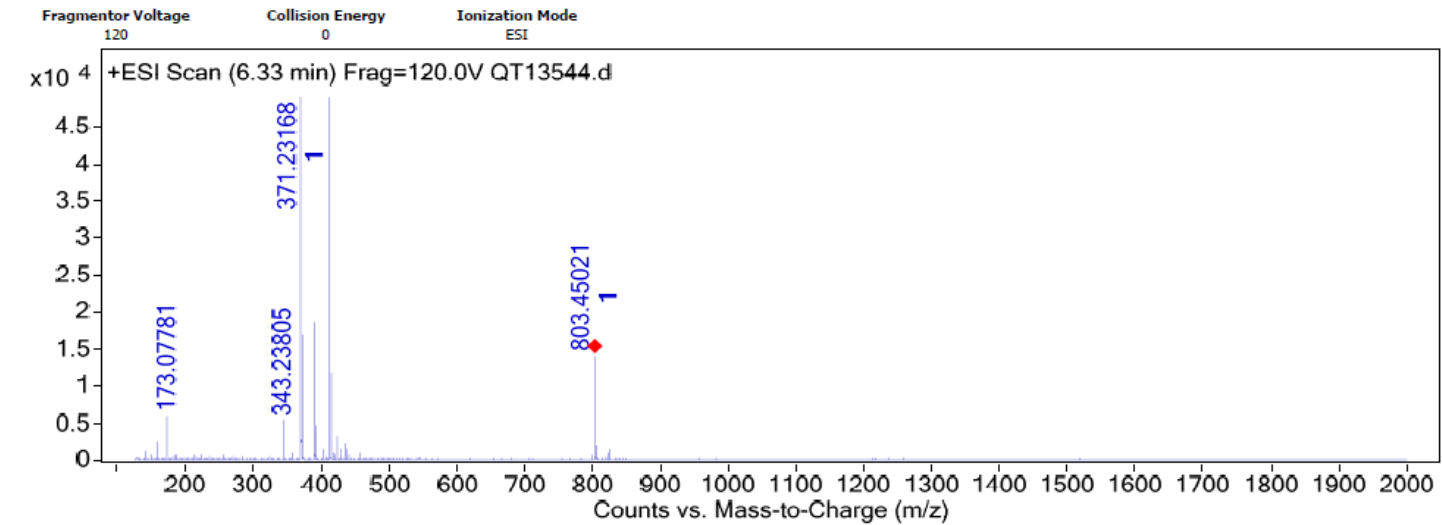

Peak List
\begin{tabular}{|l|r|l|l|l|}
\hline$m / z$ & $z$ & Abund & Formula & Ion \\
\hline 370.2339 & & 17459.1 & & \\
\hline 371.23168 & 1 & 78162.1 & & $(\mathrm{M}+\mathrm{H})+$ \\
\hline 372.23382 & 1 & 17140.2 & & $(\mathrm{M}+\mathrm{H})+$ \\
\hline 390.23557 & & 7250.7 & & \\
\hline 391.2375 & 1 & 18481 & & \\
\hline 412.22245 & & 11746.6 & $\mathrm{C} 21 \mathrm{H} 29 \mathrm{~B} \mathrm{~F} 2 \mathrm{~N} 2 \mathrm{Na} 02$ & $(\mathrm{M}+\mathrm{Na})+$ \\
\hline 413.21927 & 1 & 49685.6 & & \\
\hline 414.22293 & 1 & 11864.6 & & \\
\hline 803.45021 & 1 & 14010.8 & & $(2 \mathrm{M}+\mathrm{Na})+$ \\
\hline 804.45272 & 1 & 6359.7 & & \\
\hline
\end{tabular}

HRMS spectra of $\mathbf{3}$ 


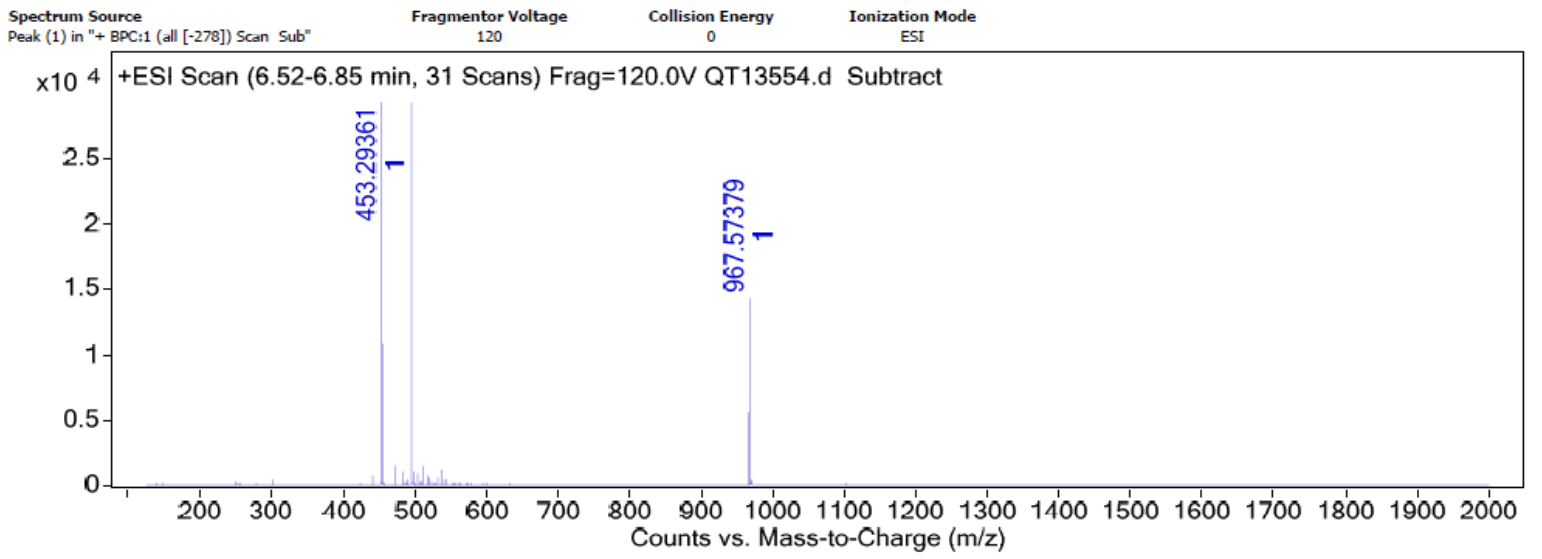

Peak List
\begin{tabular}{|l|r|l|l|l|}
\hline$m / z$ & $z$ & Abund & Formula & Ion \\
\hline 452.29675 & & 9115.7 & & \\
\hline 453.29361 & 1 & 43180.3 & & \\
\hline 453.35811 & & 3399.5 & & \\
\hline 454.29656 & 1 & 10872.5 & & \\
\hline 494.28455 & & 6281.2 & & $(\mathrm{M}+\mathrm{Na})+$ \\
\hline 495.28169 & 1 & 29297 & $\mathrm{C} 24 \mathrm{H} 35$ B F2 N6 Na O & \\
\hline 496.28464 & 1 & 7699.5 & $\mathrm{C} 24 \mathrm{H} 35$ B F2 N6 Na O & $(\mathrm{M}+\mathrm{Na})+$ \\
\hline 966.57632 & & 5642.4 & $\mathrm{C} 48 \mathrm{H} 70$ B2 F4 N12 Na O2 & $(2 \mathrm{M}+\mathrm{Na})+$ \\
\hline 967.57379 & 1 & 14338.1 & $\mathrm{C} 48 \mathrm{H} 70$ B2 F4 N12 Na O2 & $(2 \mathrm{M}+\mathrm{Na})+$ \\
\hline 968.57579 & 1 & 7086.9 & $\mathrm{C} 48 \mathrm{H} 70$ B2 F4 N12 Na O2 & $(2 \mathrm{M}+\mathrm{Na})+$ \\
\hline
\end{tabular}

HRMS spectra of BDP3-N

$\begin{aligned} & \text { Spectrum Source } \\ & \text { Peak (1) in "+ BPC:1 (all [-278]) Scan Sub" }\end{aligned}$
Fragmentor Voltage
120 $\quad \begin{gathered}\text { collision Energy } \\ 0\end{gathered} \quad \begin{gathered}\text { Ionization Mode } \\ \text { ESI }\end{gathered}$

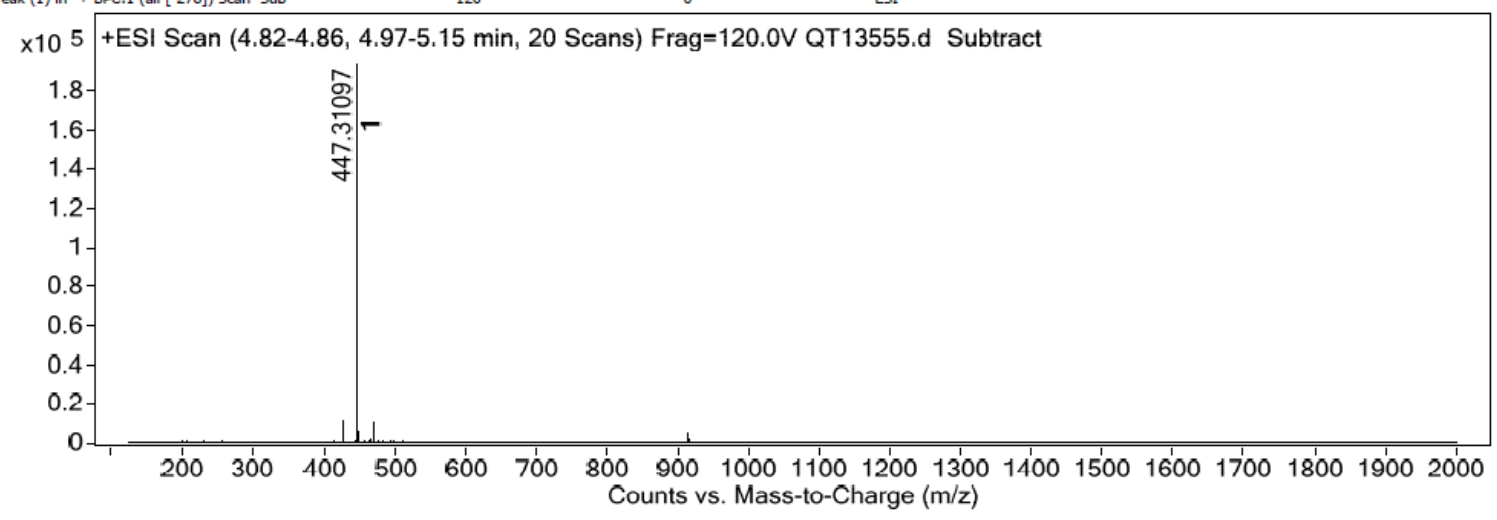

Peak List
\begin{tabular}{|l|l|l|l|l|}
\hline$m / z$ & $z$ & Abund & Formula & Ion \\
\hline 427.30384 & & 11883.1 & & \\
\hline 446.31328 & & 38322.8 & & \\
\hline 447.31097 & 1 & 193575.7 & $C 24 \mathrm{H} 38$ B F2 N4 O & $(\mathrm{M}+\mathrm{H})+$ \\
\hline 448.31305 & 1 & 45866.8 & $\mathrm{C} 24 \mathrm{H} 38 \mathrm{~B} \mathrm{~F} 2 \mathrm{~N} 4$ O & $(\mathrm{M}+\mathrm{H})+$ \\
\hline 469.29179 & & 10666 & $\mathrm{C} 24 \mathrm{H} 37 \mathrm{~B} \mathrm{~F} 2 \mathrm{~N} 4 \mathrm{Na}$ O & $(\mathrm{M}+\mathrm{Na})+$ \\
\hline
\end{tabular}

A priori: Perte de HF

HRMS spectra of BDP3

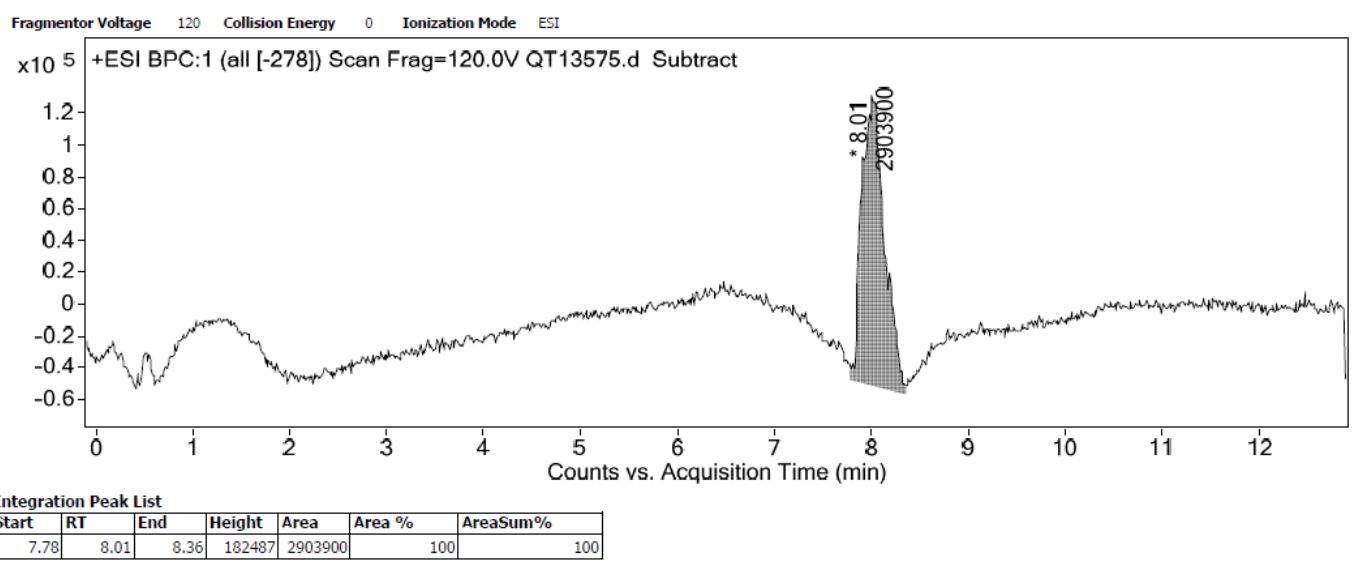

HPLC trace of BDP4-N $\mathbf{N}_{3}$ (ACN/Water, $0.1 \%$ formic acid) 


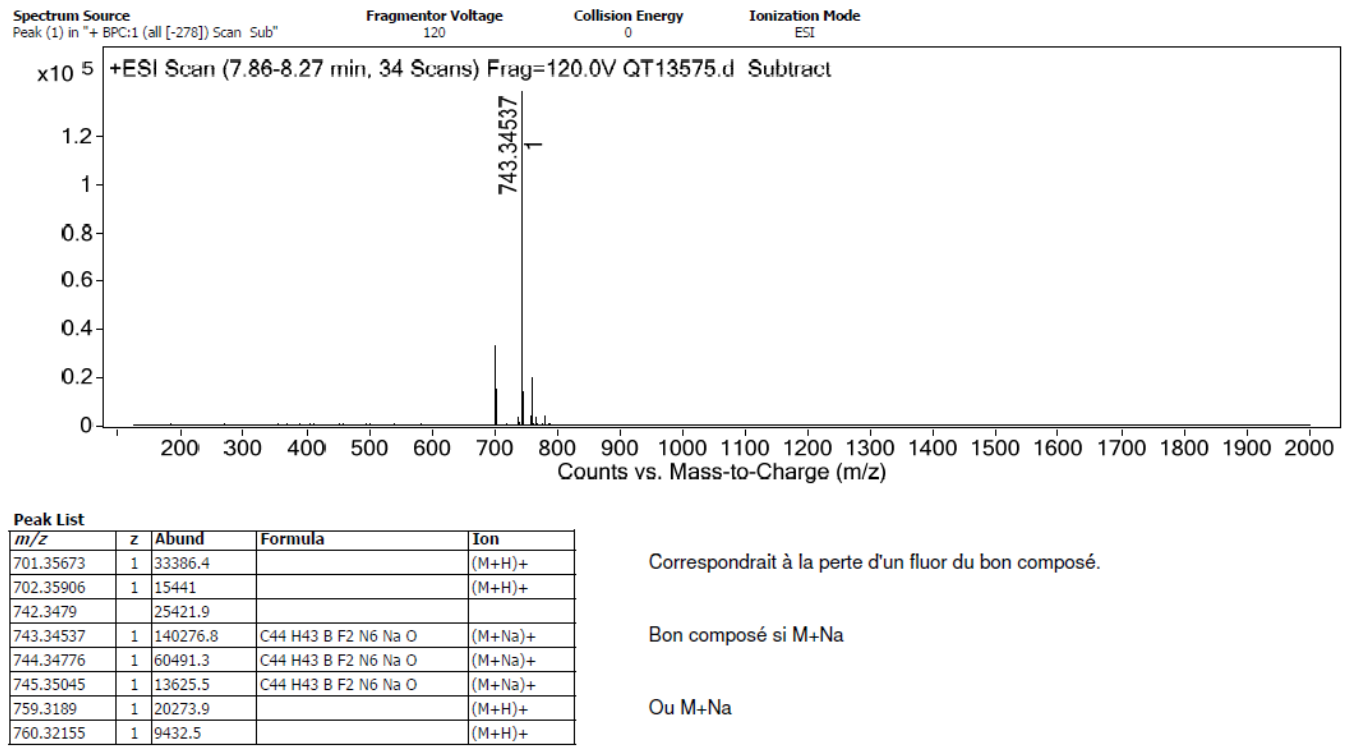

\section{LC-MS spectra of BDP4-N 3}

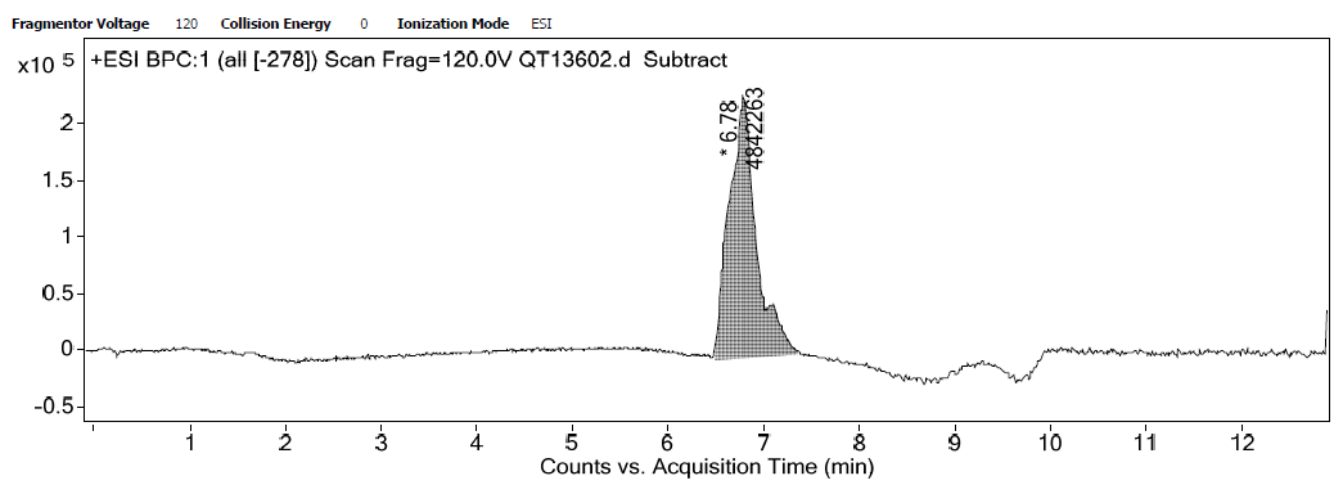

Integration Peak List

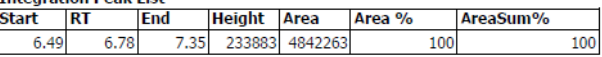

HPLC trace of BDP4 (ACN/Water, $0.1 \%$ formic acid)

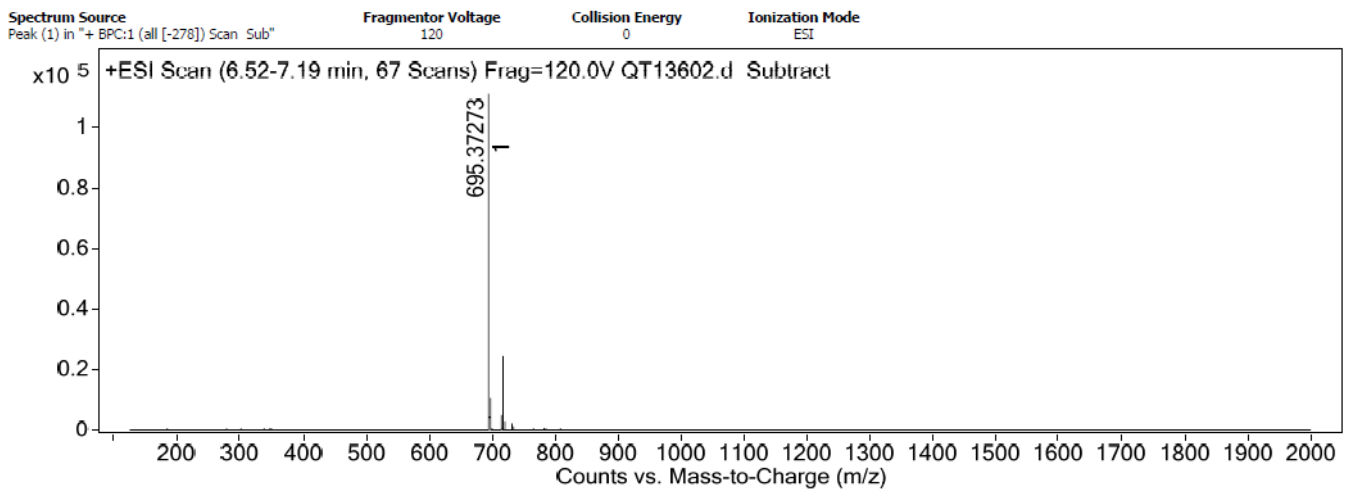

\begin{tabular}{|c|c|c|c|c|}
\hline \multicolumn{5}{|l|}{ Peak List } \\
\hline $\mathrm{m} / \mathrm{z}$ & $z$ & Abund & Formula & Ion \\
\hline 694.37479 & & 21260.1 & & \\
\hline 695.37273 & 1 & 112153.8 & $\mathrm{C} 44 \mathrm{H} 46 \mathrm{~B} F 2 \mathrm{~N} 4 \mathrm{O}$ & $(M+H)+$ \\
\hline 696.37513 & 1 & 48101.4 & $\mathrm{C} 44 \mathrm{H} 46 \mathrm{~B}$ F2 N4 O & $(\mathrm{M}+\mathrm{H})+$ \\
\hline 697.37765 & 1 & 10717.7 & $\mathrm{C} 44 \mathrm{H} 46 \mathrm{~B} \mathrm{~F} 2 \mathrm{~N} 4 \mathrm{O}$ & $(\mathrm{M}+\mathrm{H})+$ \\
\hline 717.35413 & 1 & 24758.1 & $\mathrm{C} 44 \mathrm{H} 45 \mathrm{~B} \mathrm{F2} \mathrm{N4} \mathrm{NaO} \mathrm{O}$ & $(\mathrm{M}+\mathrm{Na})+$ \\
\hline 718.35674 & 1 & 11038.1 & $\mathrm{C} 44 \mathrm{H} 45 \mathrm{~B} F 2 \mathrm{~N} 4 \mathrm{Na} \mathrm{O}$ & $(\mathrm{M}+\mathrm{Na})+$ \\
\hline
\end{tabular}

LC-MS spectra of BDP4 